\title{
HYDROLOGY OF AREA 16,
}

EASTERN COAL PROVINCE, VIRGINIA AND TENNESSEE,

- POWELL RIVER

- CLINCH RIVER

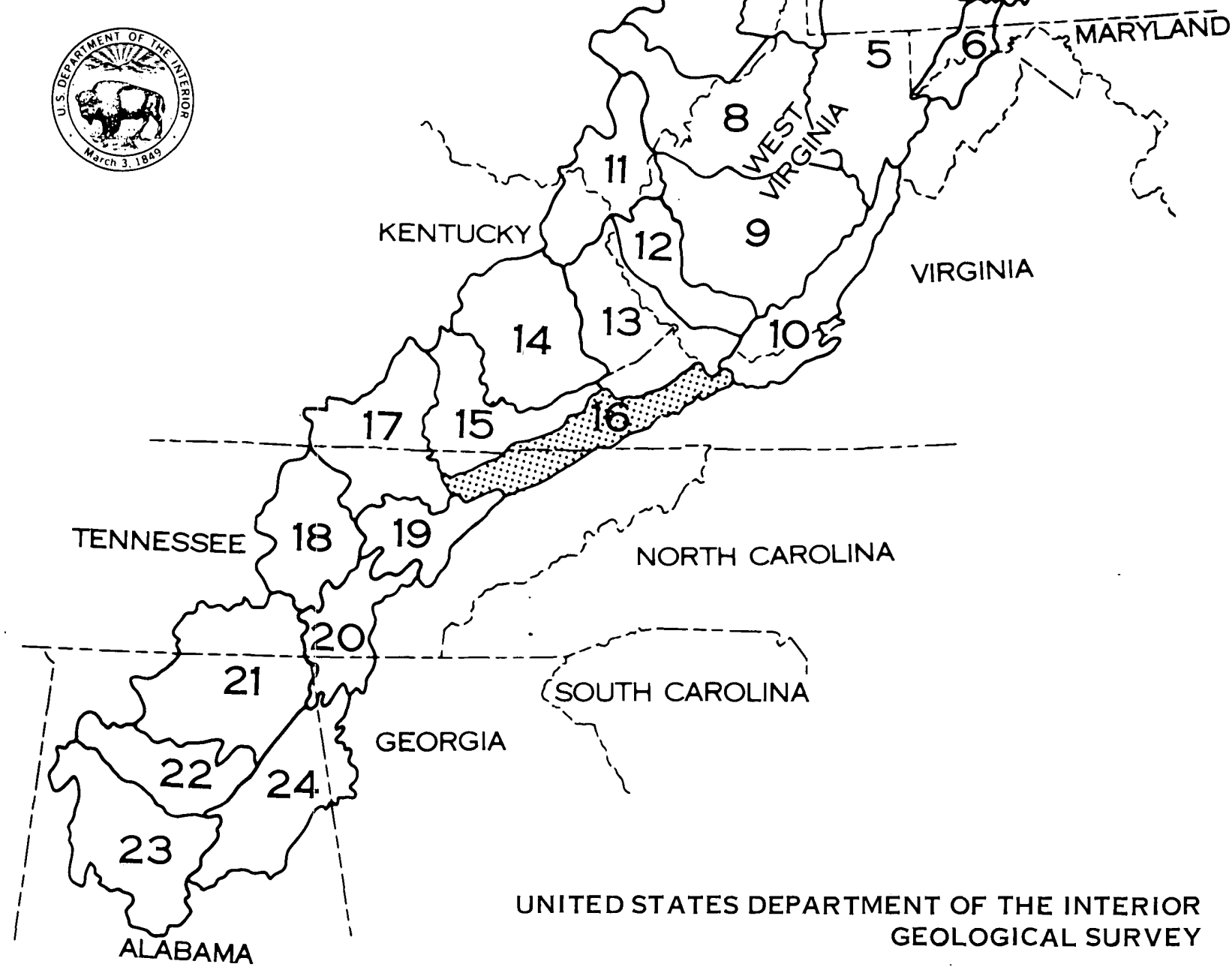




\section{HYDROLOGY OF AREA 16, EASTERN COAL PROVINCE, VIRGINIA AND TENNESSEE:}

BY

PETER W. HUFSCHMIDT AND OTHERS

U.S. GEOLOGICAL SURVEY

WATER-RESOURCES INVESTIGATIONS 81-204

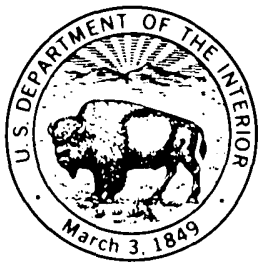

RICHMOND, VIRGINIA JUNE 1981 


\section{UNITED STATES DEPARTMENT OF THE INTERIOR}

JAMES G. WATT, SECRETARY

\section{GEOLOGICAL SURVEY}

Doyle G. Frederick, Acting Director

For additional information write to:

U.S. Geological Survey

200 W. Grace Street

Room 304

Richmond, Virginia 23220 


\section{CONTENTS}

Page

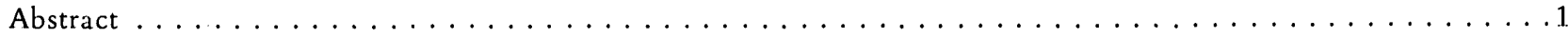

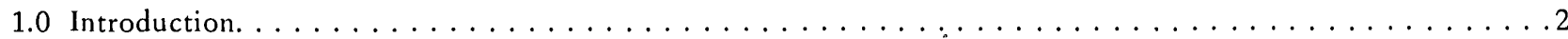

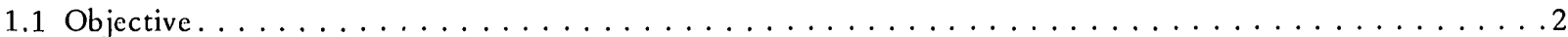
J. R. Rollo and F. A. Kilpatrick

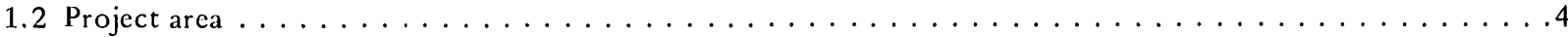
Peter W. Hufschmidt and John R. Pilling

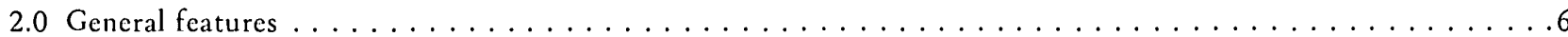

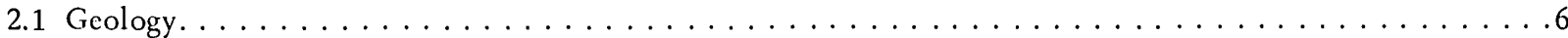
John R. Pilling

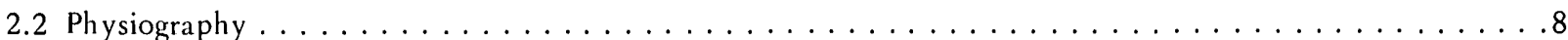
Peter W. Hufschmidt

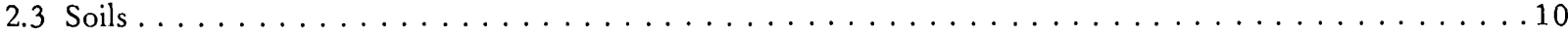
John R. Pilling

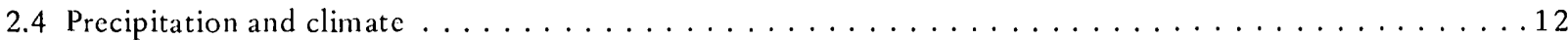
David Oliver

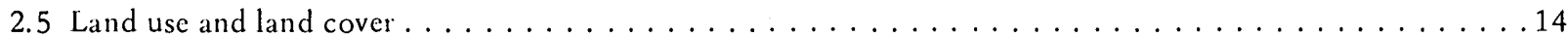
John Ponton

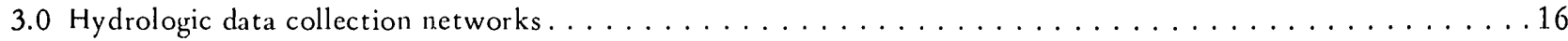

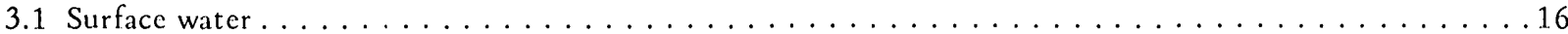
Peter W. Hufschimidt

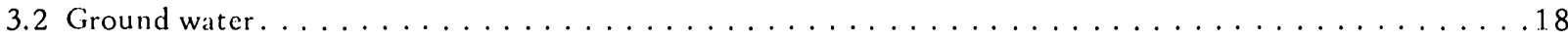
Peter W. Hufschmidt

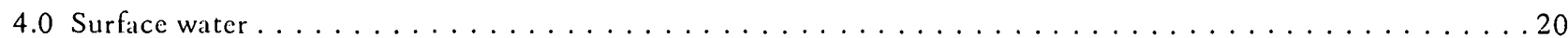

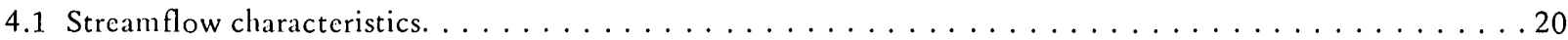
Byron J. Prugh, Jr

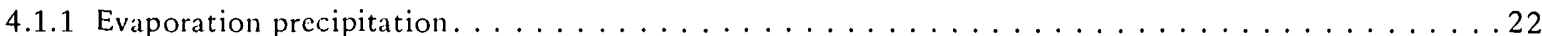
David Oliver and Byron .J. Prugh, Jr.

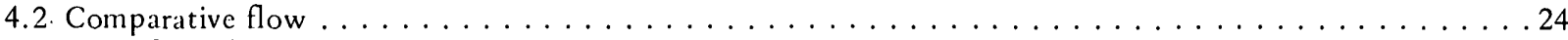
Byron J. Prugh, Jr.

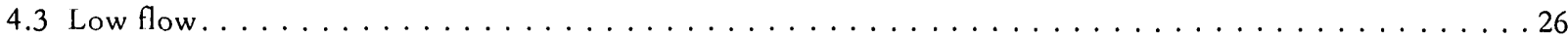
Byron J. Prugh, Jr.

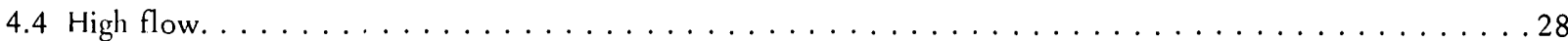
Byron J. Prugh, Jr.

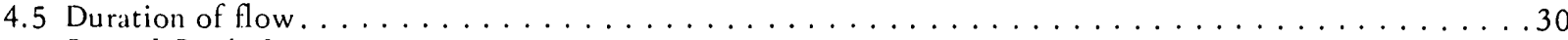
Byron J. Prugh, Jr.

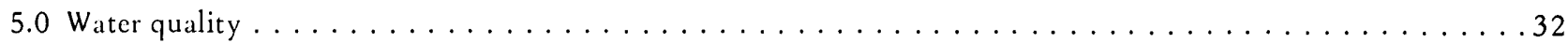

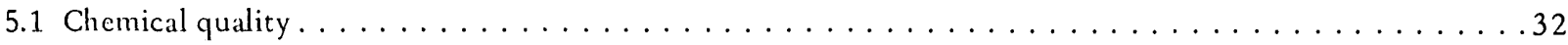

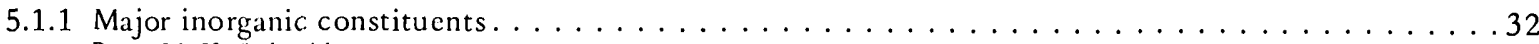
Peter W. Hufschmidt

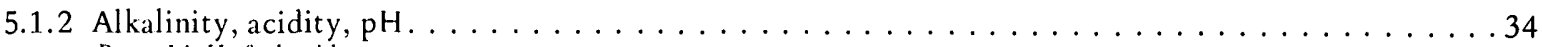
Peter W. Hufschmidt 
5.1 Chemical quality -- Continued

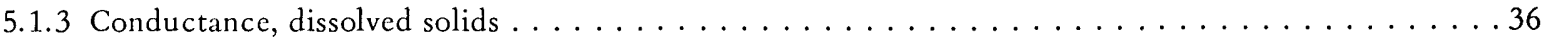
Peter W. Hufschmidt

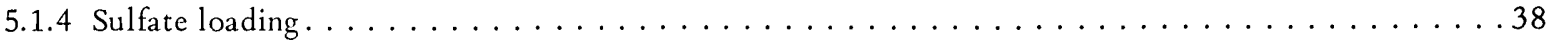
Peter W. Hufschmidt and Stanley W. Rogers

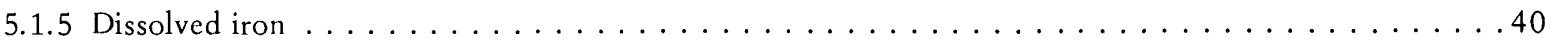
Peter W. Hufschmidt

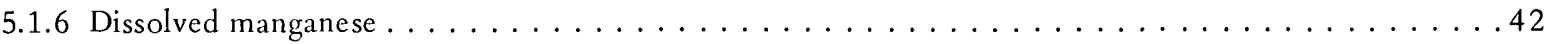
Peter W. Hufschmidt

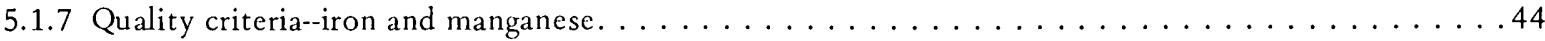
Peter W. Hufschmidt

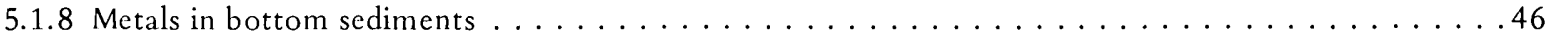
Peter W. Hufschmidt

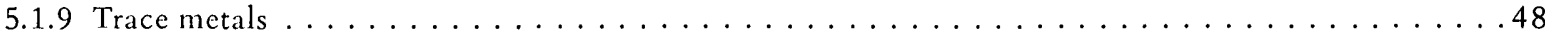
Peter W. Hufschmidt

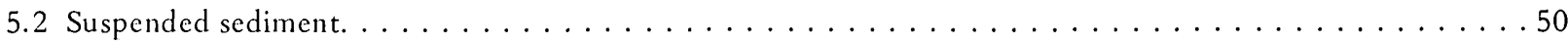
Peter W. Hufschmidt

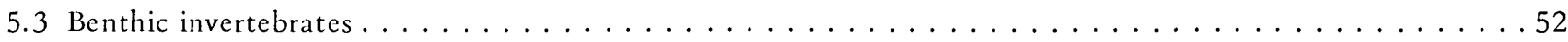
Peter W. Hufschmidt

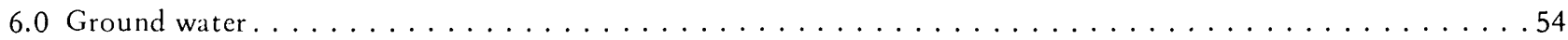

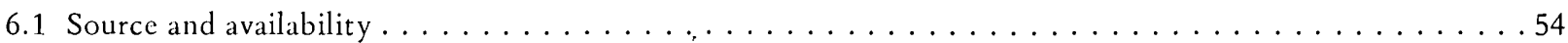
Herbert T. Hopkins and John R. Pilling

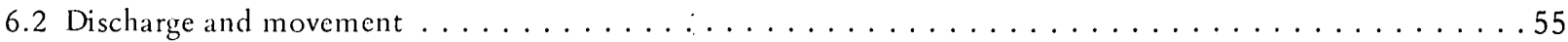
Herbert T. Hopkins and John R. Pilling

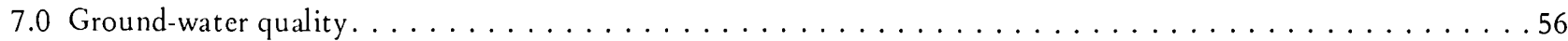
Herbert T. Hopkins and Peter W. Hufschmidt

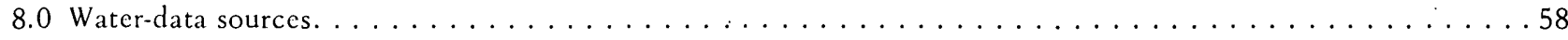

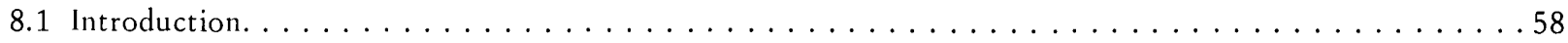

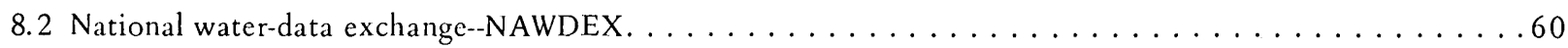

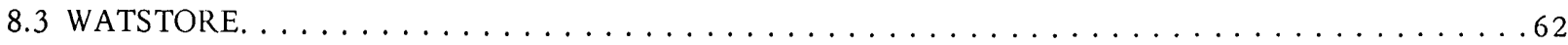

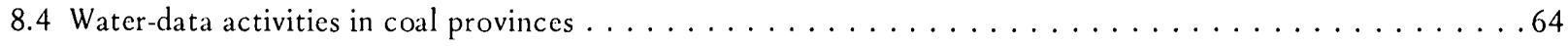

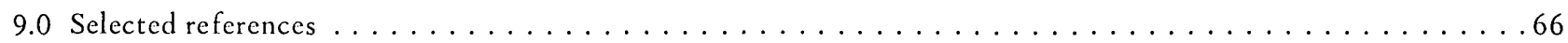

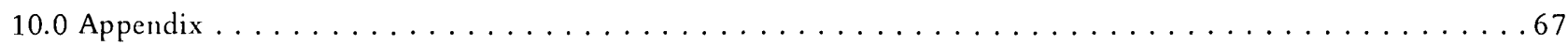




\section{FACTORS FOR CONVERTING INCH-POUND UNITS TO INTERNATIONAL SYSTEM OF UNITS (SI)}

For the convenience of readers who may want to use International System of Units (SI), the data may be converted by using the following factors:

Multiply inch-pound units

inches (in)

inches per hour (in/h)

feet $(\mathrm{ft})$

feet per mile $(\mathrm{ft} / \mathrm{mi})$

miles (mi)

square miles $\left(\mathrm{mi}^{2}\right)$

gallons per minute (gal/min)

million gallons per day (mgal/d)

cubic feet per second $\left(\mathrm{ft}^{3} / \mathrm{s}\right)$

cubic feet per second per square mile $\left[\left(\mathrm{ft}^{3} / \mathrm{s}\right) / \mathrm{mi}^{2}\right]$

tons per square mile per year $\left[\left(\right.\right.$ tons $\left.\left./ \mathrm{mi}^{2}\right) / \mathrm{yr}\right]$

micromhos per centimeter at $25^{\circ}$ Celsius $\left(\mu \mathrm{mho} / \mathrm{cm}\right.$ at $25^{\circ} \mathrm{C}$ )
By

To obtain SI units

25.4

25.4

2.54

0.3048

0.1894

1.609

2.590

0.06309

0.04381

3.785

0.02832

0.01093

0.03753

100 millimeters $(\mathrm{mm})$

millimeters per hour $(\mathrm{mm} / \mathrm{h})$ centimeters per hour $(\mathrm{cm} / \mathrm{h})$

meters ( $\mathrm{m})$

meters per kilometer $(\mathrm{m} / \mathrm{km})$

kilometers $(\mathrm{km})$

square kilometers $\left(\mathrm{km}^{2}\right)$

liters per second $(\mathrm{L} / \mathrm{s})$

cubic meters per second $\left(\mathrm{m}^{3} / \mathrm{s}\right)$ cubic meters per day $\left(\mathrm{m}^{3} / \mathrm{d}\right)$

cubic meters per second $\left(\mathrm{m}^{3} / \mathrm{s}\right)$

cubic meters per second per square kilometer $\left[\left(\mathrm{m}^{3} / \mathrm{s}\right) / \mathrm{km}^{2}\right]$

metric tons per square kilometer per year $\left[\left(\mathrm{t} / \mathrm{km}^{2}\right) / \mathrm{a}\right]$

microsiemens per meter at $25^{\circ}$ Celsius $\left(\mu \mathrm{S} / \mathrm{m}\right.$ at $\left.25^{\circ} \mathrm{C}\right)$ 

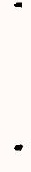


\section{HYDROLOGY OF AREA 16, EASTERN COAL PROVINCE, VIRGINIA AND \\ TENNESSEE}

BY

PETER W. HUFSCHMIDT AND OTHERS

\begin{abstract}
The Eastern Coal province is divided into 24 hydrologic reporting areas. Area 16 is in the center of the eastern edge of the Eastern Coal province and is drained by the Clinch and Powell Rivers which are tributary to the Tennessee River. The drainage area of Area 16 is 2,912 square miles.

The hydrology and water quality of the coal mining area of southwest Virginia have recently been studied. This is the first report from Virginia and part of a series of reports on the hydrology of the Eastern Coal province being prepared by the U.S. Geological Survey, Department of the Interior. The report describes the surface-water hydrology and water quality in single topic units with accompanying maps and figures.
\end{abstract}

ABSTRACT

Area 16 is underlain by the Lee, Norton, and Wise Formations of Late Mississippian and Pennsylvanian age and rocks of Mississippian, Devonian, Silurian, Ordovician, and Cambrian age. Coal- bearing strata are in the Lee, Norton, and Wise Formations along the western edge of the Clinch and Powell River valleys.

The climate is classified as central temperate with an average rainfall of 47 inches. Forest cover and agriculture dominate land use. Surface mining usually represents less than 10 percent of the surface coverage in the study basins.

This report should begin to provide coal operators and consultants with the overall picture of streamflow and water quality on a regional basis.

The U.S. Geological Survey operates a hydrologic network of 67 surface-water data-collection stations. Information collected at these stations includes data on streamflow and water-quality parameters. These data are available through the National Water Data Exchange (NAWDEX). 


\title{
1.0 INTRODUCTION \\ 1.1 OBJECTIVE
}

\section{AREA 16 REPORT SUBMITTED IN SUPPORT OF PUBLIC LAW 95-87}

\author{
Existing hydrologic conditions and identification \\ of sources of hydrologic information are presented.
}

This report provides broad hydrologic information, using a brief text with an accompanying map, chart, graph, or other illustrations for each of a series of water-resources related topics. The summation of the topical discussions provides a description of the hydrology of the area. The information contained herein should be useful to surface mine owners, operators, and consulting engineers in the preparation of permits and regulatory authorities in appraising the adequacy of permit applications.

A need for hydrologic information and analysis on a scale never before required nationally was initiated when the "Surface Mining Control and Reclamation Act of 1977" was signed into law as Public Law 95-87 on August 3, 1977. The Act established a new Federal agency, Office of Surface Mining Reclamation and Enforcement (OSM), within the U.S. Department of the Interior, whose function is to set guidelines for controlling the adverse effects of coal mining on the environment. The act provided for establishment of State-level regulatory authorities to administer and enforce State laws meeting the Federal guidelines. Further provided in the Act is the backup provision that if no satisfactory State program is developed the Federal regulations will be enforced by OSM.
In recognizing the potentially adverse impact that coal mining may have on water resources, Public Law 95-87 requires (1) that each mining-permit applicant make an analysis of the potential effects of the proposed mine on the hydrology of the mine site and adjacent area, (2) that "an appropriate Federal or State agency" provide to each mining-permit applicant "hydrologic information on the general area prior to mining," and (3) that measures be taken by mining permittees to control adverse effects of mining on the "hydrologic balance" and reclamation of the land.

This report broadly characterizes the hydrology of Area 16 in Virginia and Tennessee. The hydrologic information presented or available through sources identified in this report may be used in describing the hydrology of the "general area" of any proposed mine. Furthermore, it is expected that this hydrologic information will be supplemented by the lease applicant's specific site data as well as data from other sources to provide a more detailed picture of the hydrology of the area in the vicinity of the mine and the anticipated hydrologic consequences of the mining operation. 


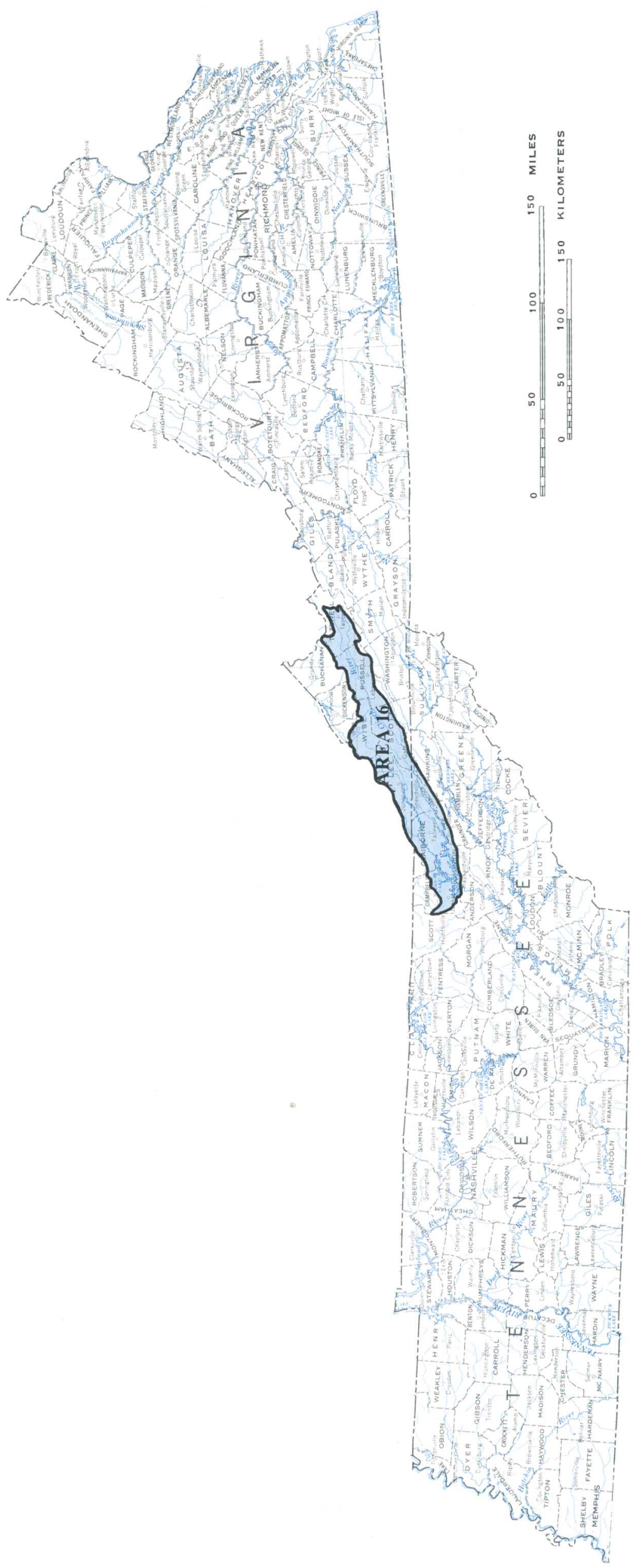

苞

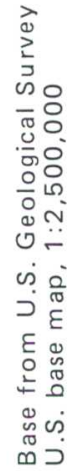

1.0 INTRODUCTION 1.1 OBJECTIVE 


\title{
1.0 INTRODUCTION (Continued) \\ 1.2 PROJECT AREA
}

\section{HYDROLOGY AND WATER RESOURCES DESCRIBED FOR AREA 16 IN VIRGINIA AND TENNESSEE}

\author{
This report describes the hydrology and water \\ resources in Area 16 in the center of the \\ Eastern Coal province in Virginia and Tennessee.
}

The Eastern Coal province is divided into 24 hydrologic reporting areas (facing page). Hydrologic units (drainage basins) or parts of units are combined to form each area.

Area 16 includes parts of Wise, Lee, Scott, Russell, and Tazewell Counties in Virginia, and Campbell, Anderson, Union, Grainger, Claiborne, and Hancock Counties in Tennessee. Area 16 lies within the Tennessee River basin along the eastern edge of the Appalachian Coal basin. The surface drainage of Area 16 is 2,912 square miles.
The coal-producing western part of Area 16 is in the Appalachian Plateau physiographic province. The eastern part lies within the Valley and Ridge province.

The area encompasses the upper part of the Clinch River basin from its source in Virginia to Norris Lake, in Tennessee, and the Powell River basin from its source in Virginia to Norris Lake. The Guest River and the North Fork Powell River are major subbasins tributary to the Clinch and Powell Rivers, respectively. 


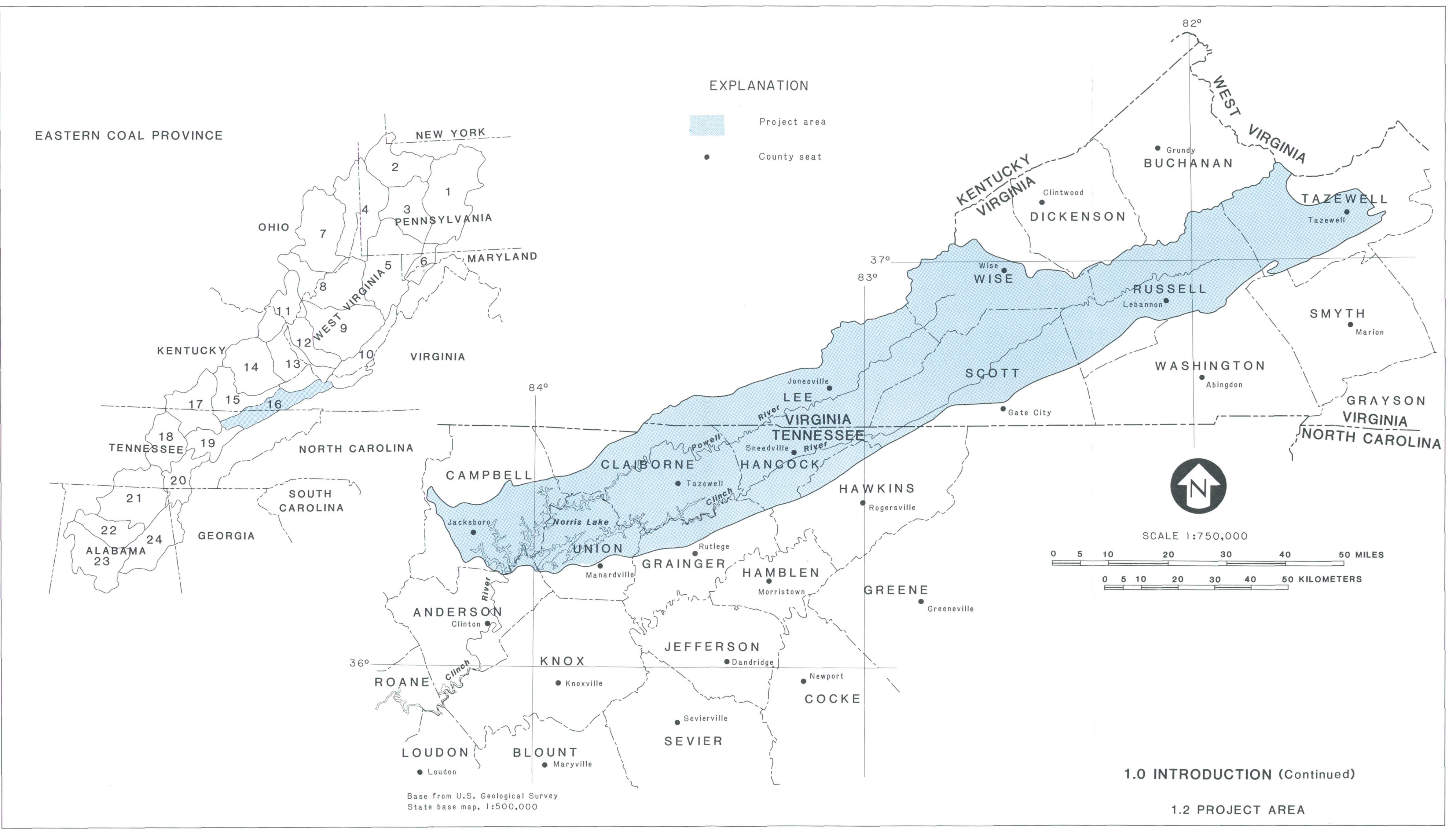




\title{
2.0 GENERAL FEATURES \\ 2.1 GEOLOGY
}

\section{CAMBRIAN THROUGH PENNSYLVANIAN-AGE SEDIMENTARY ROCKS UNDERLIE AREA 16}

\author{
Sedimentary rocks that range in age from Cambrian \\ through Pennsylvanian underlie most of Area 16. \\ The economically important coal beds occur only in \\ the Pennsylvanian rocks.
}

\begin{abstract}
The Clinch and Powell River basins of southwest Virginia and northeast Tennessee lie in the Appalachian Plateau and the Valley and Ridge physiographic provinces (Fenneman, 1938). These provinces are characterized by rugged and mountainous topography consisting of deep V-shaped valleys with steep slopes and narrow, winding ridges. These surficial features have been etched out of the extensive strata of sedimentary rocks, which range from Cambrian through Pennsylvanian age.
\end{abstract}

The rock formations of Area 16 are highly deformed into arches (anticlines) and troughs (synclines) with few areas of horizontal strata. Faults displace the strata in many areas. These folded and faulted structures are due to the strong horizontalcompressional forces acting on the region since late Paleozoic time. 


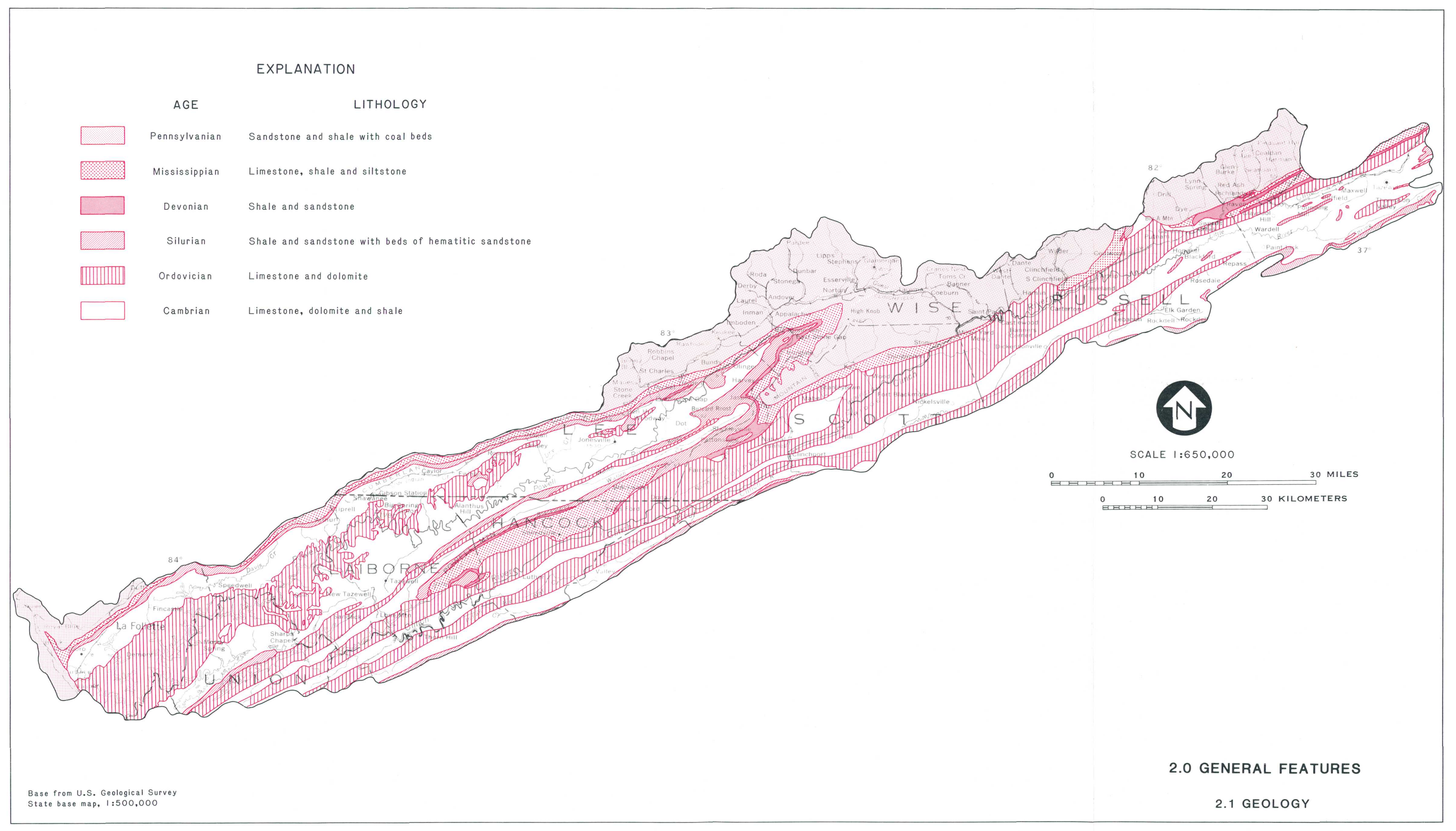




\subsection{GENERAL FEATURES (Continued)}

2.2 PHYSIOGRAPHY

\section{AREA 16 LIES WITHIN TWO PHYSIOGRAPHIC PROVINCES}

\section{Area 16 lies within two physiographic provinces: Appalachian Plateau, and Valley and Ridge.}

Area 16 lies within the Appalachian Plateau and Valley and Ridge physiographic provinces (Fenneman, 1938).

The part of Area 16 underlain by the coal-bearing Pennsylvanian sedimentary rocks lies within the Appalachian Plateau. Both the Clinch and Powell Rivers drain the eastern border of this broad plateau which is characterized by steep valleys and rough terrain.

East of the Appalachian Plateau lies the Valley and Ridge province. The parallel valleys and ridges of this province extend from central Alabama northeastward to northern Pennsylvania. The Clinch and Powell Rivers, which lie in parallel valleys, drain into the Tennessee River to the southwest. 


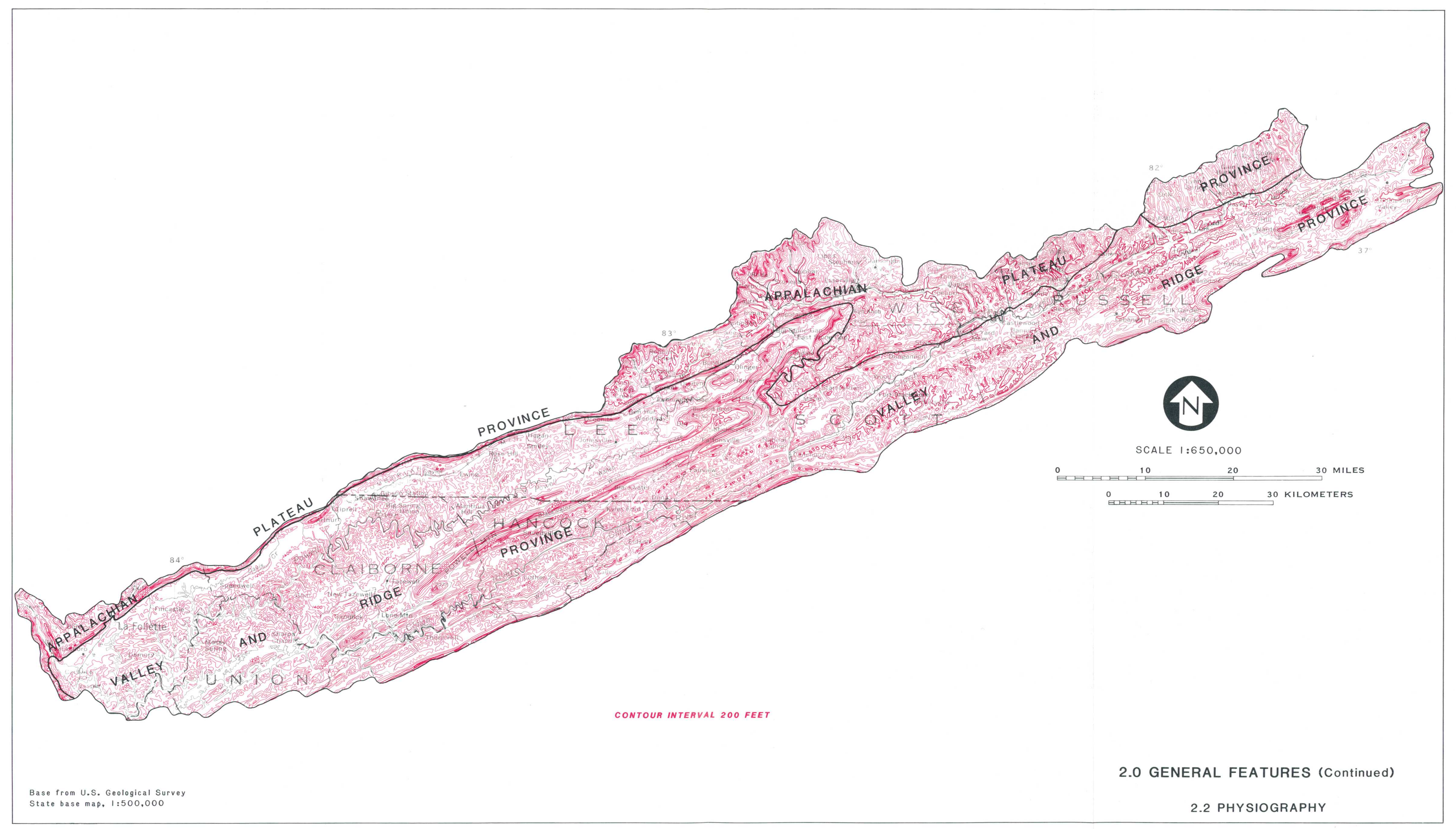




\title{
2.0 GENERAL FEATURES (Continued) 2.3 SOILS
}

\section{SOILS ARE FORMED IN PLACE AND REFLECT UNDERLYING ROCK TYPE}

\author{
Soils on steep to moderate slopes are usually \\ formed on acid shale and sandstone. Gently \\ sloping soil on uplands and in valleys are \\ usually formed on limestone.
}

Soils in Area 16 generally have moderate to high permeability, moderate acidity, and moderate to high erosion potential. Factors influencing the usefulness of a soil include texture, soil depth, permeability, slope, fertility, and vegetative cover. Increased erosion often results from the removal of vegetation during surface mining, road construction, and other disruptive activities.

The general soil map shows the distribution of the three soil associations (USDA, SCS, 1979). The soils formed on mountains include the DeKalb-
Berks-Weikert soils and are characterized as steep to very steep soils formed mainly in residuum on acid sandstone, shale, and phyllites. Soils formed on uplands of dissected valleys include the Calvin-Berks soils and are characterized as gently sloping to steep soils formed in residuum on acid shale. Soils formed on uplands in limestone valleys include the Frederick-Elliber soils and are characterized as gently sloping to steep soils formed in residuum on limestone, sandstone, and shale. 


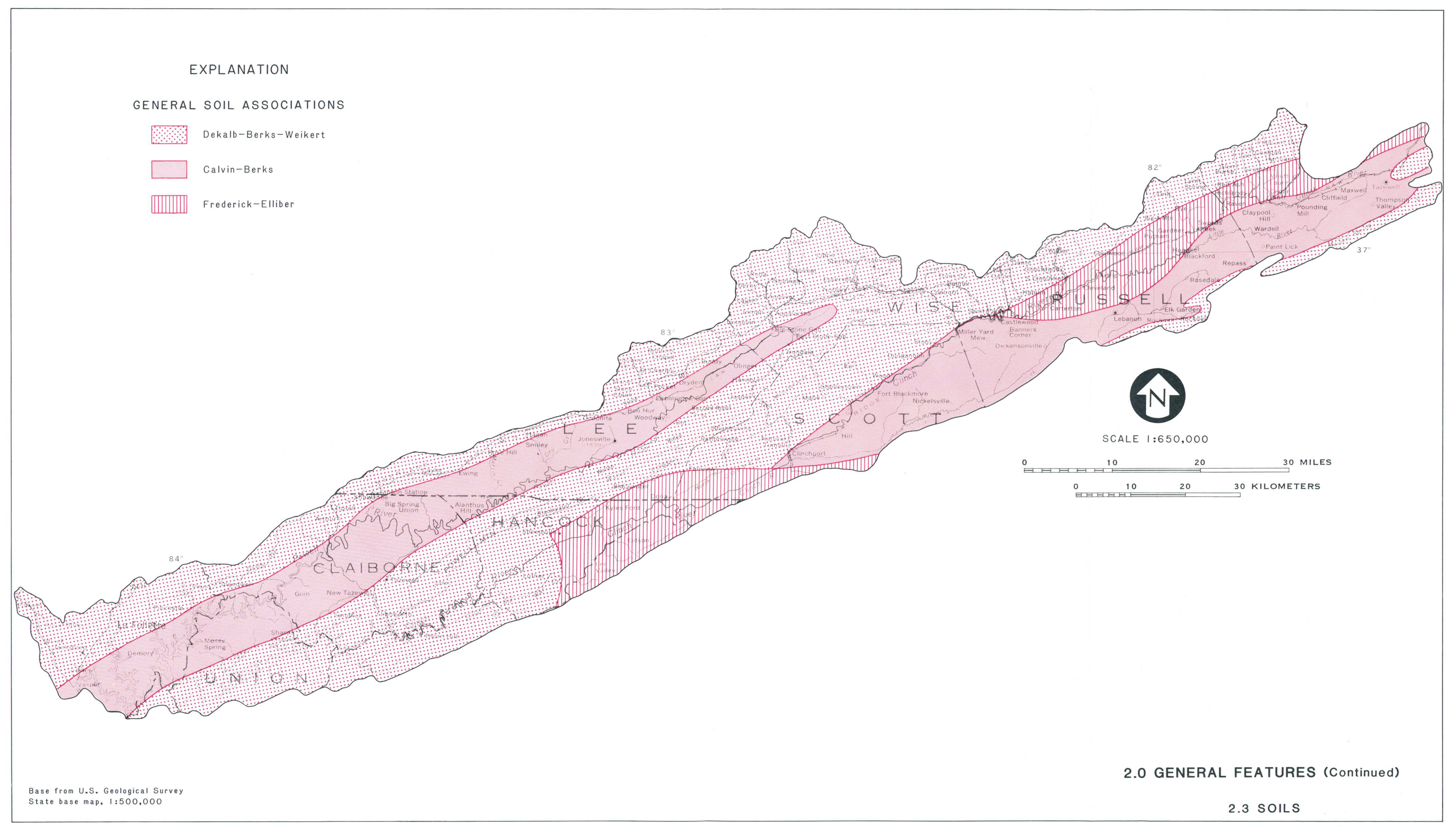




\title{
2.0 GENERAL FEATURES (Continued) \\ 2:4 PRECIPITATION AND CLIMATE
}

\section{MODERATE CLIMATE CHARACTERIZES AREA 16}

\author{
The climate of Area 16 is characterized by \\ moderate temperatures and average annual \\ precipitation of 47 inches.
}

\begin{abstract}
Most of the area's rainfall is derived from warm, moist air masses moving northward from the Gulf of Mexico. Precipitation develops as these air masses cross the Appalachian Mountains and meet cooler northern air circulating in a counterclockwise direction. As the storms move eastward, they leave more precipitation in the western part of the area than in the eastern part. The southern part of the area also receives more rainfall than the northern part. The net effect is a precipitation gradient decreasing from about 50 inches in the southwest to 38 inches in the northeast (Tennessee Valley Authority, 1977; Na-
\end{abstract}

tional Oceanic and Atmospheric Administration, 1979).

The average temperature for Area 16 is $53^{\circ} \mathrm{F}$. Annual high temperatures of between $90^{\circ} \mathrm{F}$ and $105^{\circ} \mathrm{F}$ occur from July through September, and annual low temperatures of from $0^{\circ} \mathrm{F}$ to $-23^{\circ} \mathrm{F}$ occur from December through February.

The climate and distribution of precipitation are strongly affected by the topography, with large variations in rainfall and temperature occurring throughout the area. 


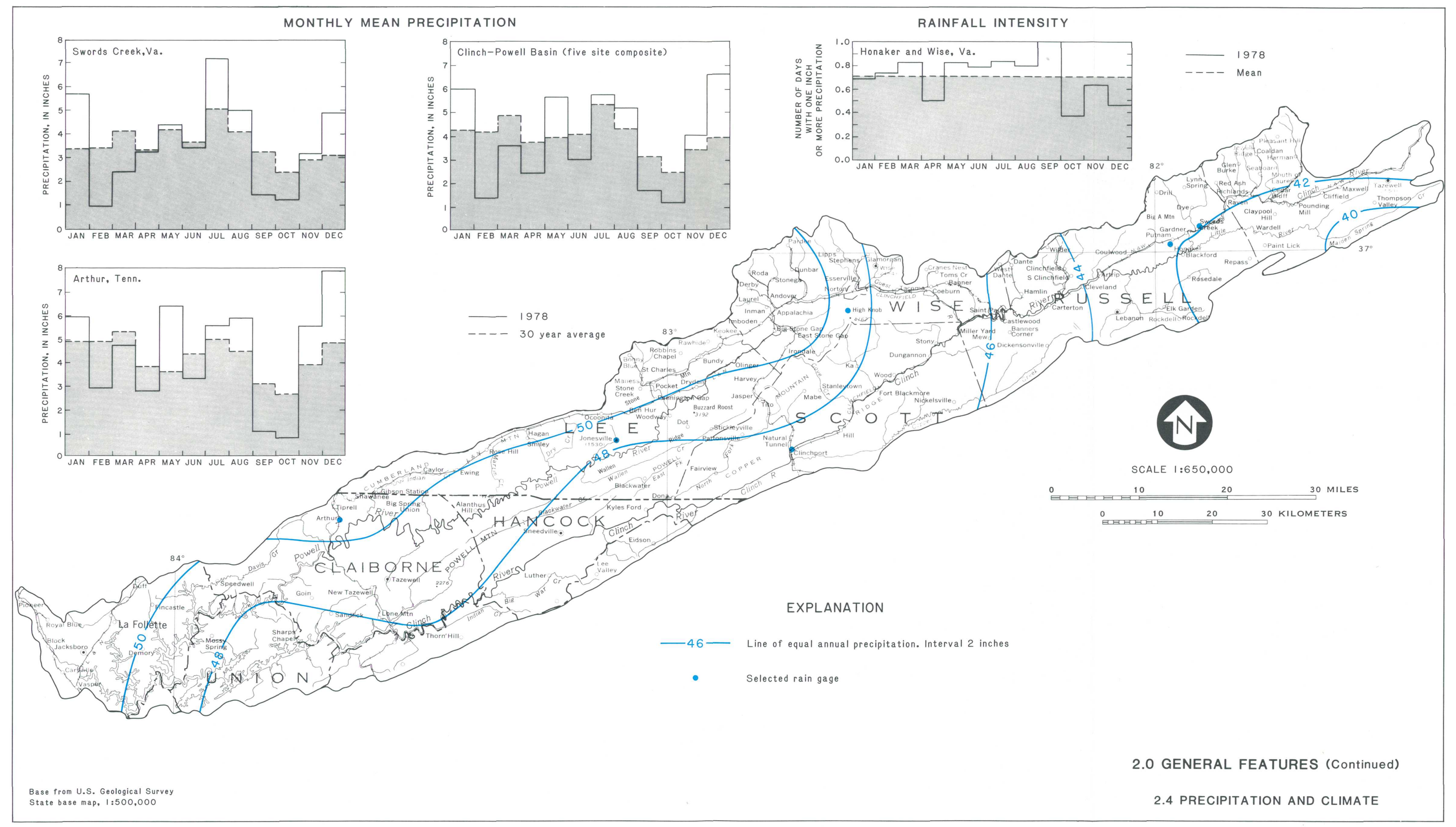




\title{
2.0 GENERAL FEATURES (Continued) \\ 2.5 LAND USE AND LAND COVER
}

\section{FOREST LAND DOMINATES AREA 16}

\author{
Forested land dominates Area 16, and about \\ one-fourth of the area is used for agri- \\ cultural purposes. Past and present surface \\ mining activity covers a very small part of \\ the basins studied, less than 5 percent of \\ the total study area.
}

Six land-use categories were identified for Area 16 and are shown in table 2.5-1. The percentage of surface-mined land in individual subbasins is shown in figure 2.5-1 (Source: S.W. Virginia 208 report, 1978).

Surface-water flow, ground-water recharge, and quality may be controlled by the predominant land use. Changes in land use may adversely affect the hydrologic interactions in an area. Understanding the distribution of different land uses aids understanding of existing water data. For example, surface mining previously forested land will result in the removal of vegetative cover, allowing faster runoff and in- creased erosion and sediment loading. Road construction, timber harvesting, and field preparation for cropland are similar activities that may increase sedimentation. Conversely, revegetation of surfacemined land may reduce runoff, increase infiltration, and reduce sediment loading.

Land-use and land-cover maps and information may be found in U.S. Geological Survey open-file reports entitled "Land Use Series." Information on the series is available from the National Cartographic Information Center, U.S. Geological Survey, National Cenier, Reston, Virginia 22092. 


\section{EXPLANATION}

Clinch and Powell River drainage basins

-..- Clinch-Powell drainage basin boundary

6.2 Percentage of subbasin surface area strip-mined

* No land use data available

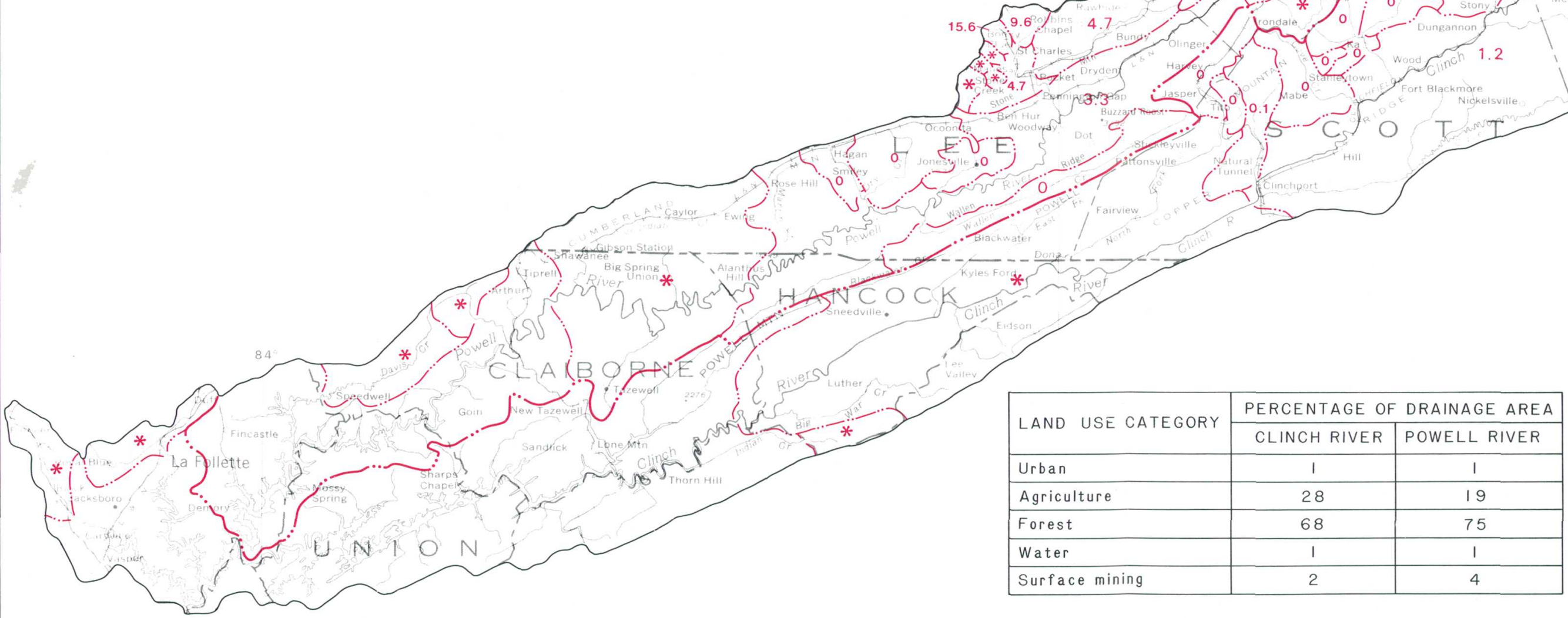

TABLE 2.5-1 Land use, percentage of drainage area. 


\title{
3.0 HYDROLOGIC DATA COLLECTION NETWORKS \\ 3.1 SURFACE WATER
}

\section{SURFACE WATER NETWORK OF AREA 16 CONSISTS OF 67 STATIONS}

\author{
The current surface-water hydrologic data collec- \\ tion network in Area 16 consists of 67 stations, \\ of which 9 are continuous-record gaging stations \\ and 58 are partial-record stations.
}

The hydrologic data collection network in Area 16 was established in 1979 in order to provide information required by Public Law 95-87. To provide both spatial and temporal distribution of water data, 67 data collection stations were established on streams and rivers. Temporal information is defined through the operation of 9 continuous-record gaging stations at which river-stage data are recorded continuously and water-quality data are collected monthly. These stations are on major rivers draining Area 16. Spatial variability of streamflow and water quality are obtained from 58 partial-record stations which are sampled quarterly. These stations are on headwater streams (at 1:500,000 scale) and are sam- pled on a synoptic basis. Synoptic sampling involves intense area-wide coverage during a short period of time. The facing map shows the location of stations within the hydrologic data collection network of Area 16

Further information about the period of record and type of data, as well as the actual data, is available from computer storage through National Water Data Exchange (NAWDEX) and in published annual U.S. Geological Survey reports "Water Resources Data for Virginia" and "Water Resources Data for Tennessee." 
EXPLANATION

320 Station number

Continuous-record gaging station and quality-of-water site

$\checkmark \quad$ Quality-of-water site and measurement of discharge

$\checkmark$ Chemical-measurement site

Temperature-measurement sit

$\checkmark$ Sediment-measurement sit

$\checkmark$ Biological-measurement site

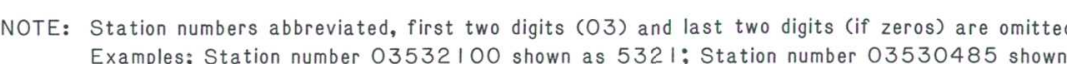
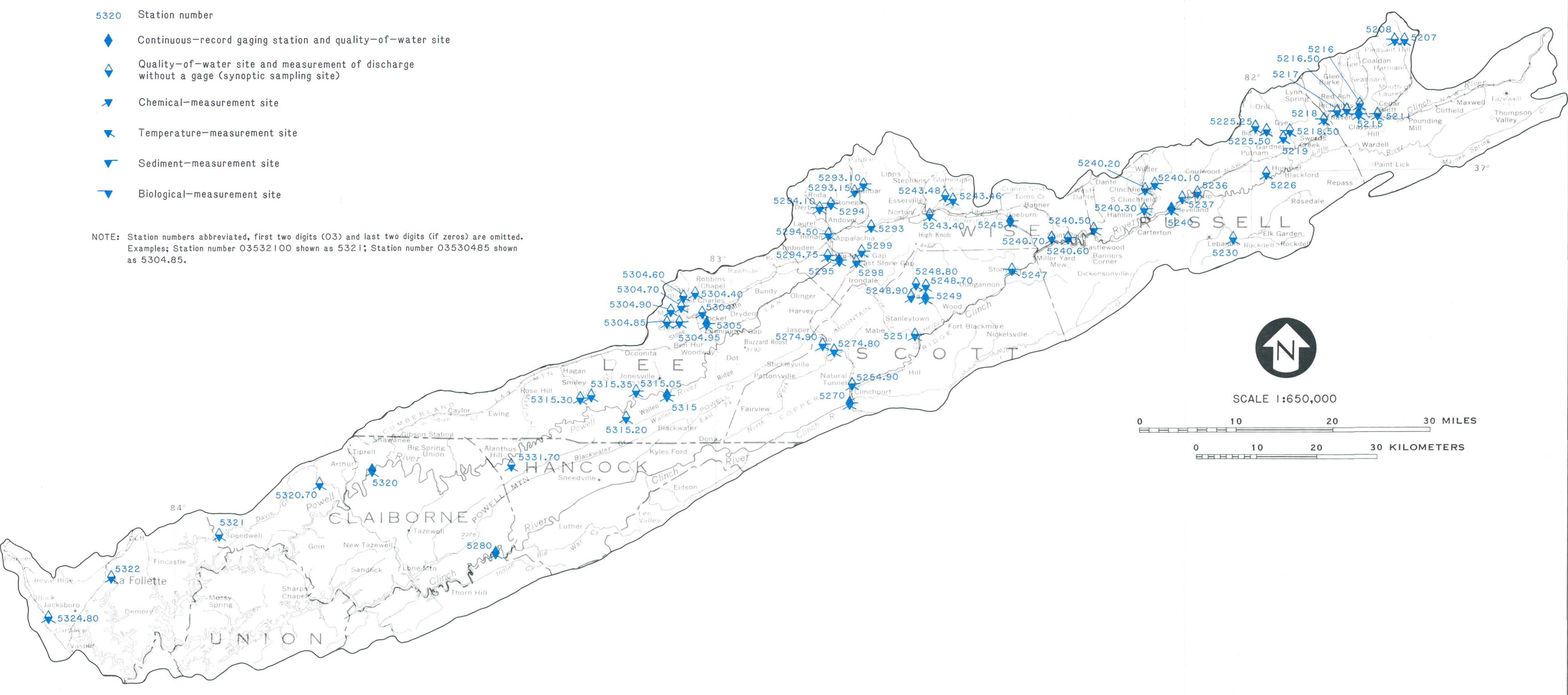

3.0 HYDROLOGIC DATA COLLECTION NETWORKS 


\title{
3.0 HYDROLOGIC DATA COLLECTION NETWORKS (Continued) \\ 3.2 GROUND WATER
}

\section{GROUND-WATER INFORMATION IS SCANT IN AREA 16}

\author{
The U.S. Geological Survey does not currently \\ operate observation wells in Area 16. Ground- \\ water information is available from the Virginia \\ State Water Control Board and local public health \\ departments.
}

The observation well network operated by the U.S. Geological Survey in Virginia and Tennessee does not extend into Area 16. To date the Survey has conducted no extensive ground-water studies in this area. Ground-water information used in this report was obtained from the Virginia State Water Control Board and from local public health departments. 
For further information contact:

Virginia State Water Control Board 2109 N. Hamilton Street

Richmond, Virginia 23219

(804) $786-3551$

Virginia State Department of Health

109 Governor Street

James Madison Building

Richmond, Virginia 23219

(804) $786-3551$ 


\title{
4.0 SURFACE WATER
}

4.1 STREAMFLOW CHARACTERISTICS

\section{SEASONAL VARIATION IN RAINFALL AND EVAPORATION AFFECTS STREAMFLOW}

\author{
Seasonal variations in rainfall and evapotrans- \\ piration cause fluctuations in streamflow. \\ Mean discharge of the Clinch and Powell Rivers \\ increases downstream as tributaries enter the \\ mainstem rivers.
}

The seasonal changes in streamflow reflect the quantity of rainfall and evapotranspiration. Figure 4.1-1 shows a daily discharge hydrograph. In this hydrograph, the effects of winter rains are shown by streamflow exceeding the long-term average flow. Streamflow recedes during the summer months as evapotranspiration increases and rainfall decreases.
Minimum streamflow occurs during the late summer months when rainfall is at a minimum and baseflow is maintained by ground-water discharge. Streamflow increases again in the fall due to decreased evapotranspiration, with a corresponding increase in ground-water storage. 


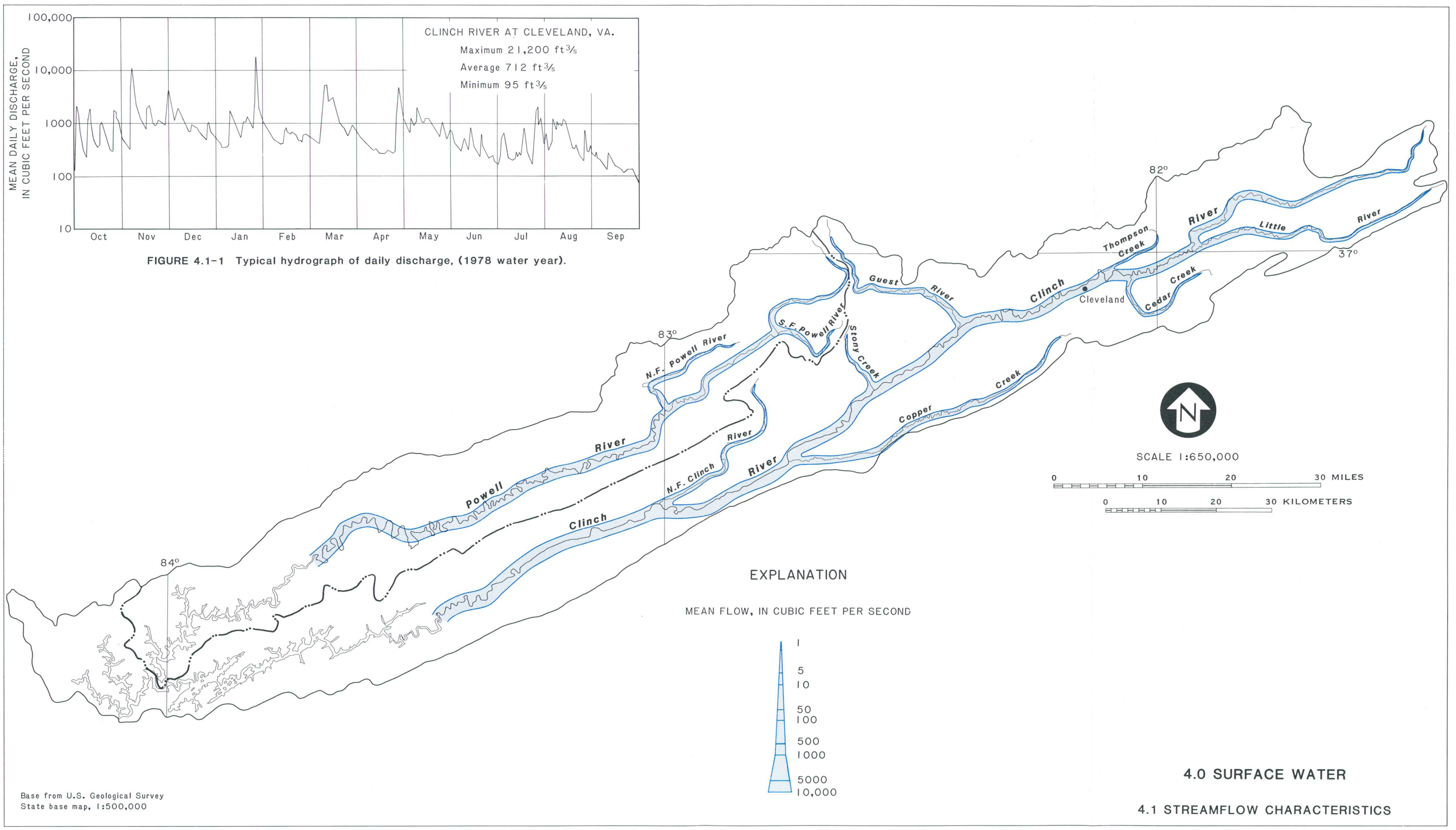




\title{
4.0 SURFACE WATER (Continued) \\ 4.1 STREAMFLOW CHARACTERISTICS (Continued) \\ 4.1.1 EVAPORATION PRECIPITATION
}

\section{NET EVAPORATION LOSS OCCURS FROM APRIL TO OCTOBER IN AREA 16}

\author{
Net evaporative loss of up to 2 inches per \\ day occurs between April and October. Maxi- \\ mum runoff occurs in March.
}

\begin{abstract}
The combination of precipitation and evaporation curves with mean runoff values delineate two distinct periods in the annual cycle. Starting at the convergence point of the precipitation and evaporation curves in October, a period of relatively low evaporation rates and high precipitation values commences and leads to increasing runoff levels. As the gap between evaporation and precipitation grows, runoff levels increase until March. The region yields maximum runoff in March. As the evaporation and precipitation curves reconverge in April, the drier half of the annual cycle begins. After the annual peak in March, runoff values show the effect of increasing evaporation and decreased precipitation and begin to drop off. From April through July, increas-
\end{abstract}

ing precipitation is exceeded by increasing evaporation, and runoff continues to decline and reaches the year's lowest levels during September. As the curves meet again in October, the annual cycle is completed.

The evaporation curve (fig. 4.1.1-A) was developed from data collected at the Tennessee Valley Authority station at Jefferson City, Tennessee, from 1942-69. The precipitation curves for the same time period are similar for stations throughout Area 16. Mean runoff values were developed from data collected at U.S. Geological Survey stream-gaging stations for this period of time (fig. 4.1.1-B). 

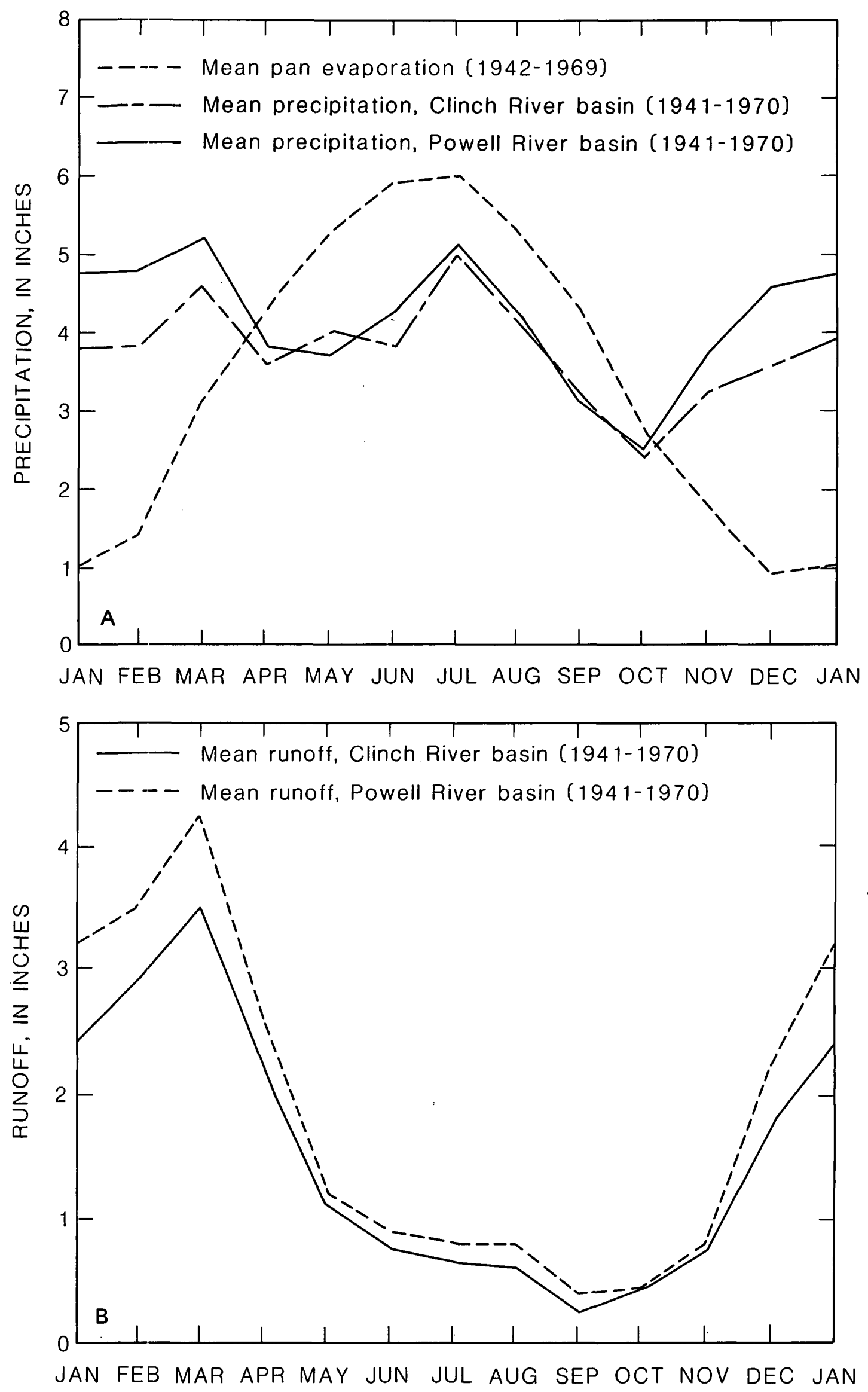

FIGURE 4.1.1 Precipitation and evaporation compared to runoff in Area 16.

4.0 SURFACE WATER (Continued)

4.1 STREAMFLOW CHARACTERISTICS (Continued)

4.1.1 EVAPORATION/PRECIPITATION 


\title{
4.0 SURFACE WATER (Continued) \\ 4.2 COMPARATIVE FLOW
}

\section{STREAMFLOW VARIES WITH GEOLOGY AND MINING}

\author{
Area-weighted streamflow values, calculated from \\ measurements made during September 1979, range \\ from 0.01 to 1.26 cubic feet per second per \\ square mile of drainage area. This wide vari- \\ ation is attributed to differences in geology \\ and mining activity.
}

Discharge measurements made at 60 sites in Area 16 during September 1979 reflect the differences in geology between various parts of the basin. In the upper portions of the Clinch and Powell River basins, streams originating in Pennsylvanian sandstones on the western side of the basins yielded lower unit flows than Cambrian and Ordovician limestones and dolomites. In the middle section of the Clinch River basin and the eastern portion of the Powell River basin, streams that drain the Stone Mountain area, which is underlain principally by Pennsylvanian sandstone and shale, produced the highest flows. Streams along the western flanks of both basins are underlain by similar rock types but yielded unit flows that vary widely. These differences in streamflow may be attributed to differences in the extent of mining. 


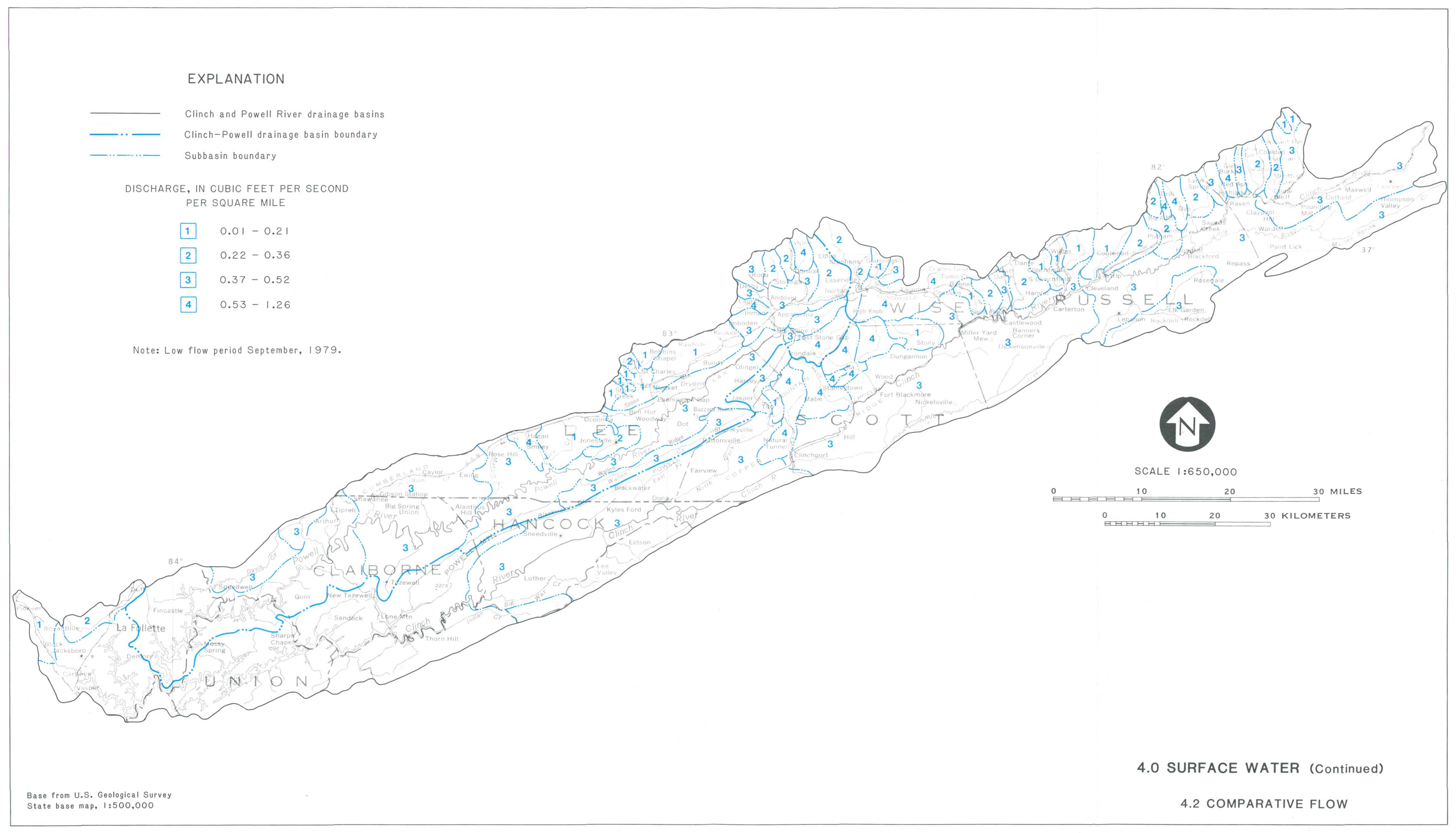




\title{
4.0 SURF ACE WATER (Continued) 4.3 LOW FLOW
}

\section{SANDSTONES YIELD LOWER UNIT FLOWS THAN LIMESTONES}

\author{
The 7-day, 10-year unit low flows are similar \\ for the mainstem Clinch and Powell Rivers. \\ However, Pennsylvanian sandstones yield lower \\ unit flows than limestones of Cambrian and \\ Ordovician age.
}

The 7-day, 10-year unit low flows for the mainstems of the Clinch and Powell Rivers are similar. In the Clinch River basin, unit low flows decrease downstream as far as Speers Ferry, Virginia, below which they begin to increase. Within the Powell River basin, however, unit low flows consistently increase downstream. This trend reflects the diminishing influence of the Pennsylvanian sandstones, shales, and coals of the Cumberland Plateau which drain into these basins from the west.

The Guest River and North Fork Powell River, whose drainage basins are underlain chiefly by the Pennsylvanian sandstones, have significantly lower unit flows than does Copper Creek, which originates in the Cambrian and Ordovician limestones and dolomites on the east side of the Clinch River basin. There is extensive coal-mining activity in the Guest and North Fork Powell River basins but it is uncertain whether the differences in low-flow characteristics are due primarily to mining activities or to differences in geology.

Flow characteristics of streams may be summarized on a unit basis so that streams having different drainage areas can be directly compared (fig. 4.3-1, 4.3-2). Absolute values of these characteristics are also useful in comparing relative quantities of flow (table 4.3-1). 


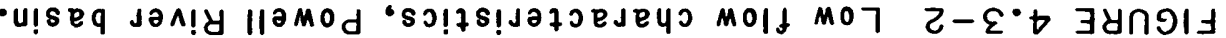

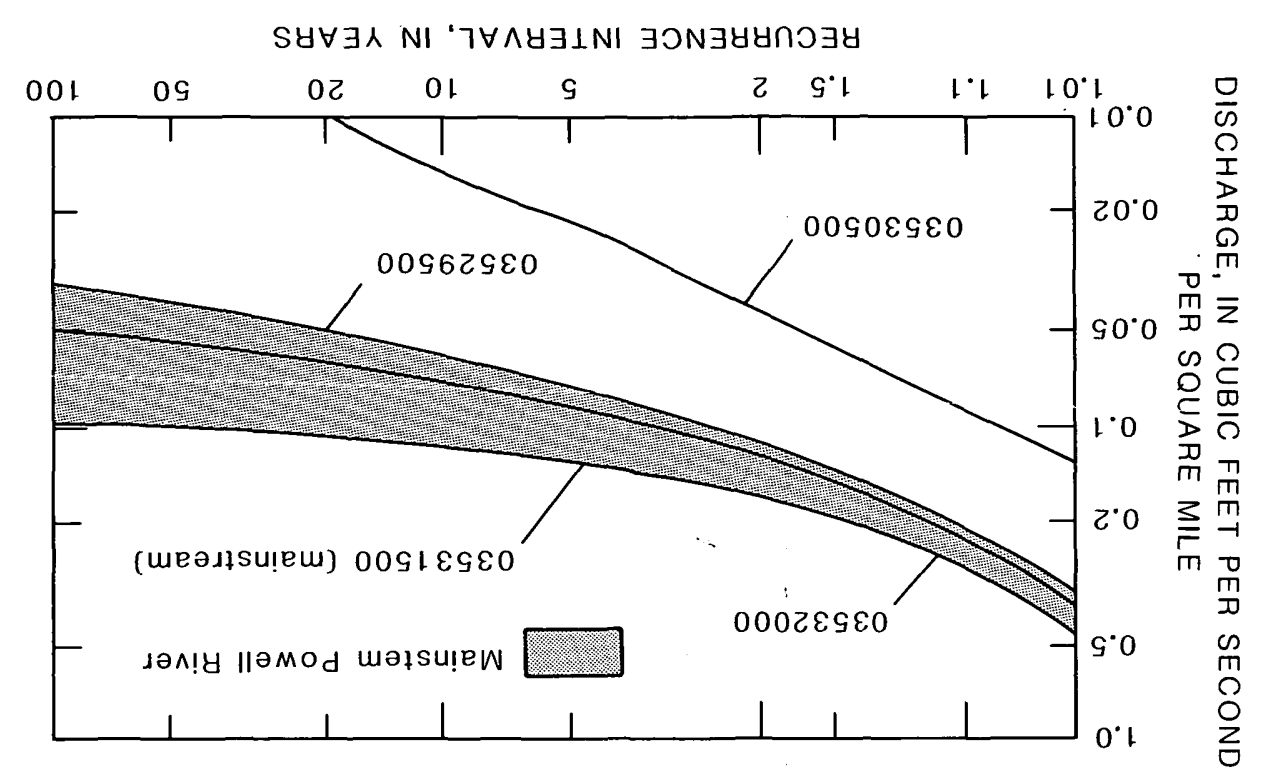

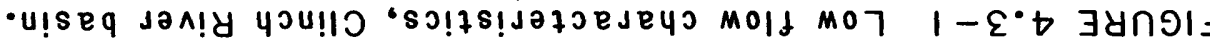

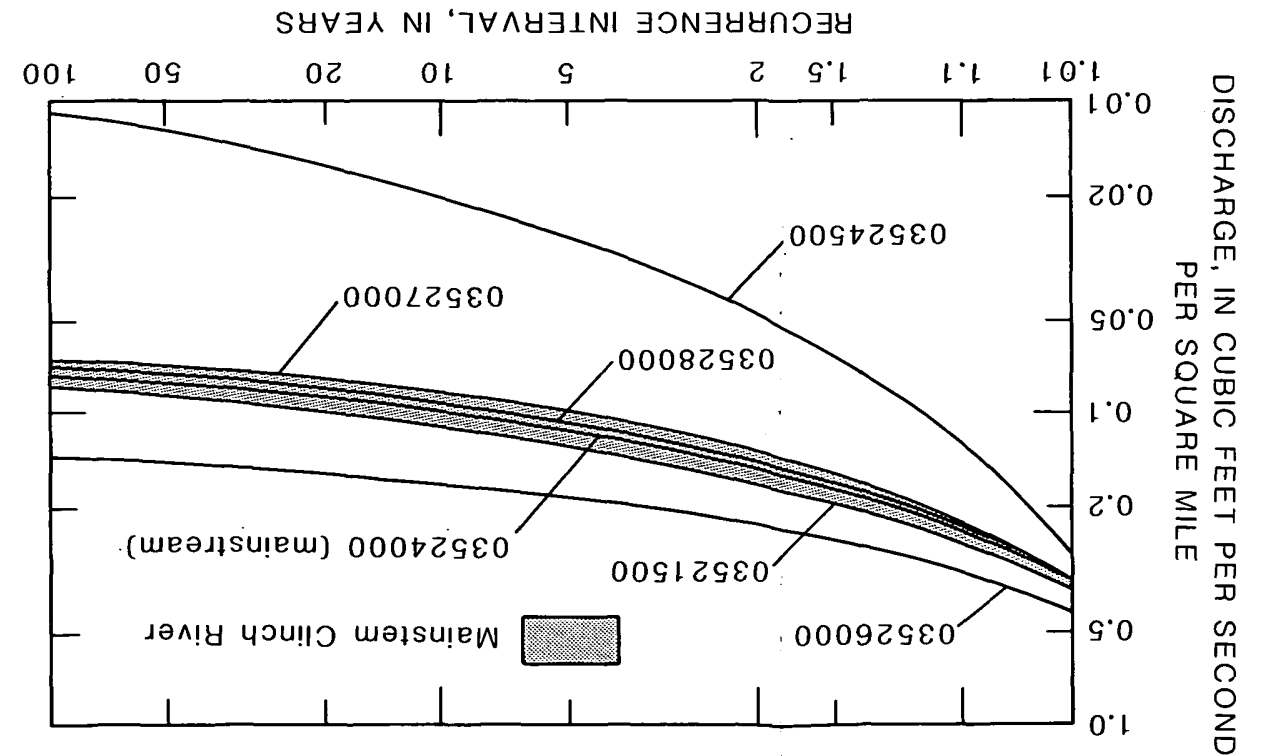

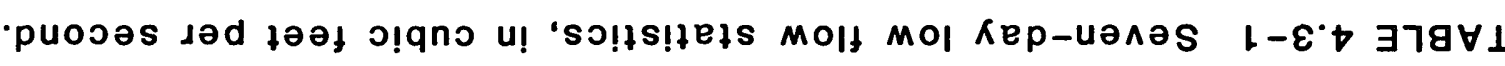

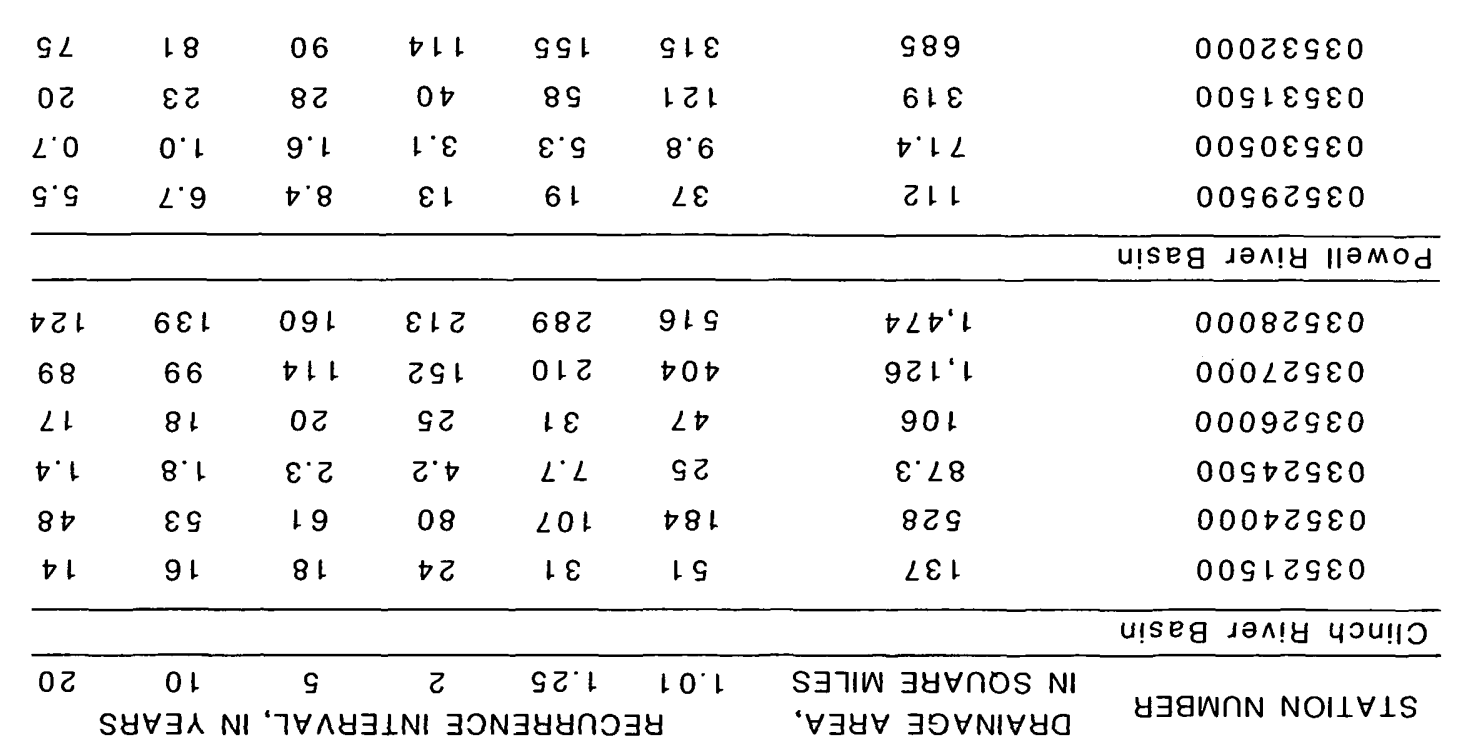




\title{
4.0 SURFACE WATER (Continued) \\ 4.4 HIGH FLOW
}

\section{STORM RUNOFF IN POWELL RIVER BASIN IS GREATER THAN IN THE CLINCH RIVER BASIN}

\author{
Storm runoff is greater in the Powell River basin \\ than in the Clinch River basin. The major trib- \\ utaries to the Powell River have much steeper \\ stream channel slope than tributaries to the \\ Clinch River.
}

\begin{abstract}
Unit runoff during storm periods is considerably greater in the Powell River basin than it is in the Clinch. This difference is likely due to the effects of the steeper stream channel slopes of the tributaries to the Powell River basin (refer to the topographic map in section 2.2). Major tributaries of both rivers also show higher yields than do the mainstems.
\end{abstract}

For areas receiving equal rainfall, drainage area and slope are the two variables which most strongly affect high flows but drainage area configuration, land use, vegetation, soil type, and precipitation intensity are also important. As recurrence intervals become greater, the effects of individual basin features, such as land use and soil type, become less important and there are fewer differences in flow characteristics between the tributaries and the mainstem of a basin.

Flow characteristics of streams are often summarized on a unit basis so that streams of varying drainage areas can be compared directly (fig. 4.4-1 and 4.4-2). However, the absolute values of these streamflow statistics are also useful in comparing relative quantities of flow (table 4.4-1). 


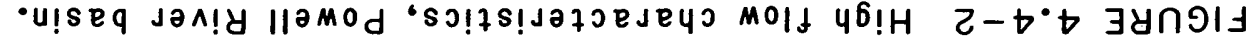

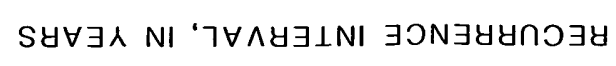

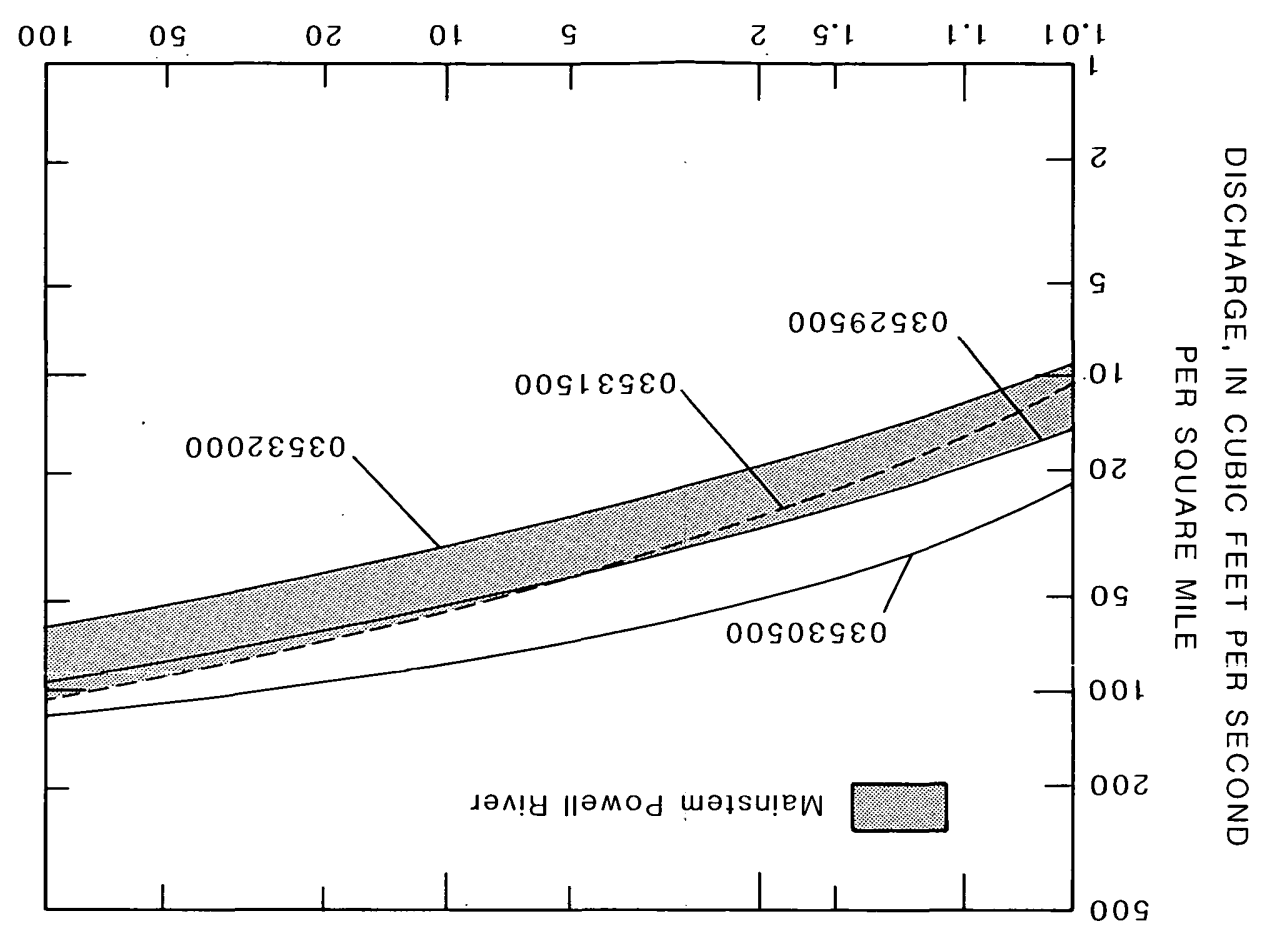

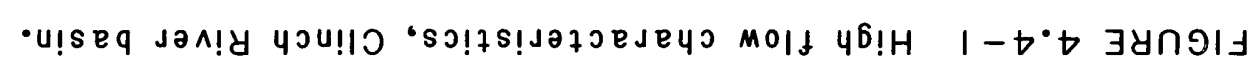

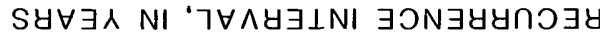

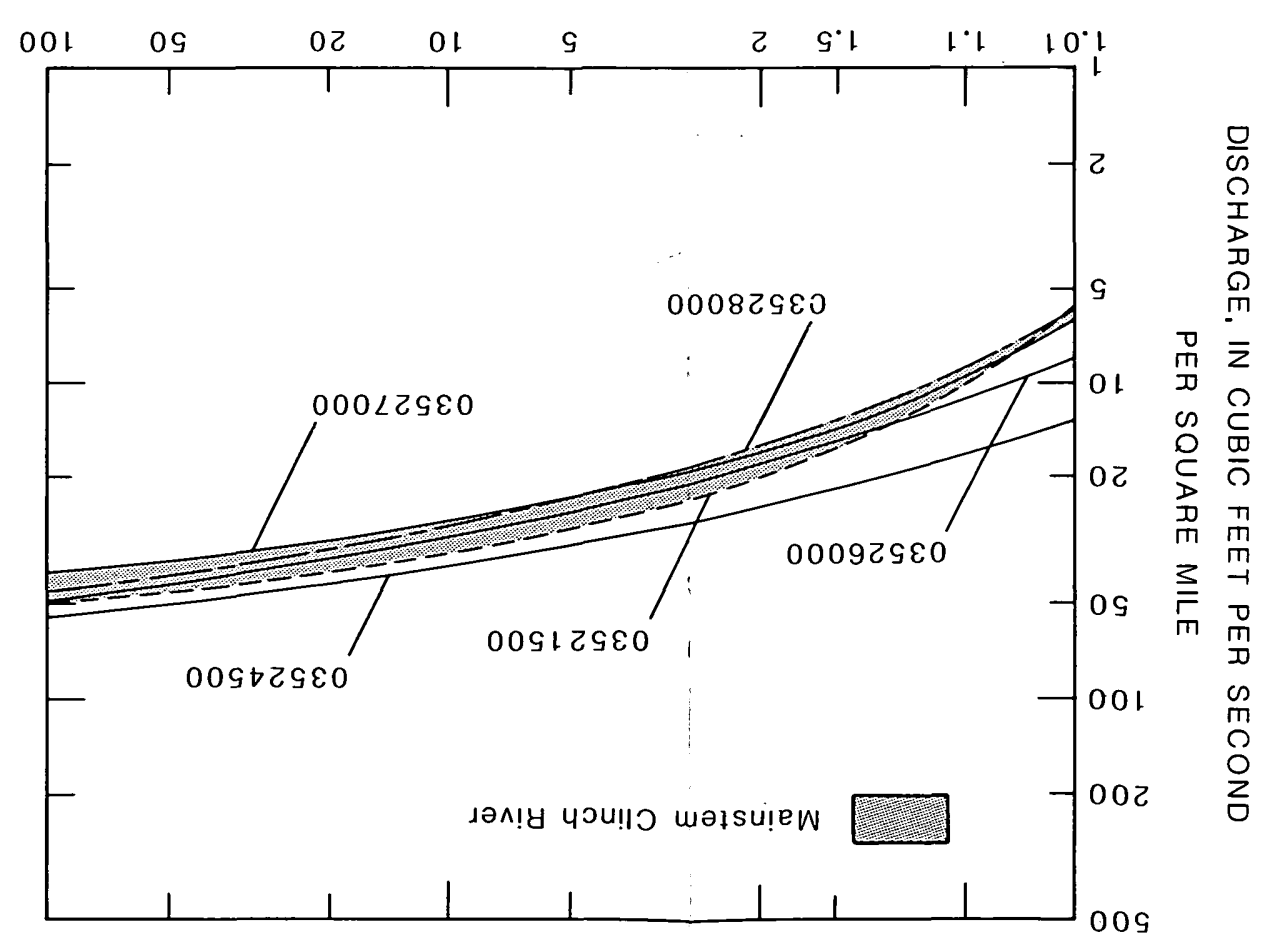

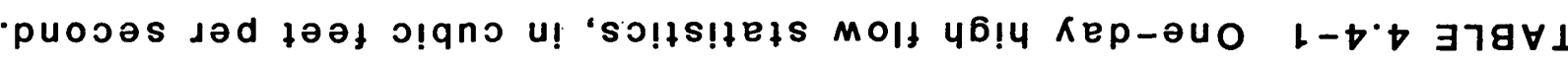

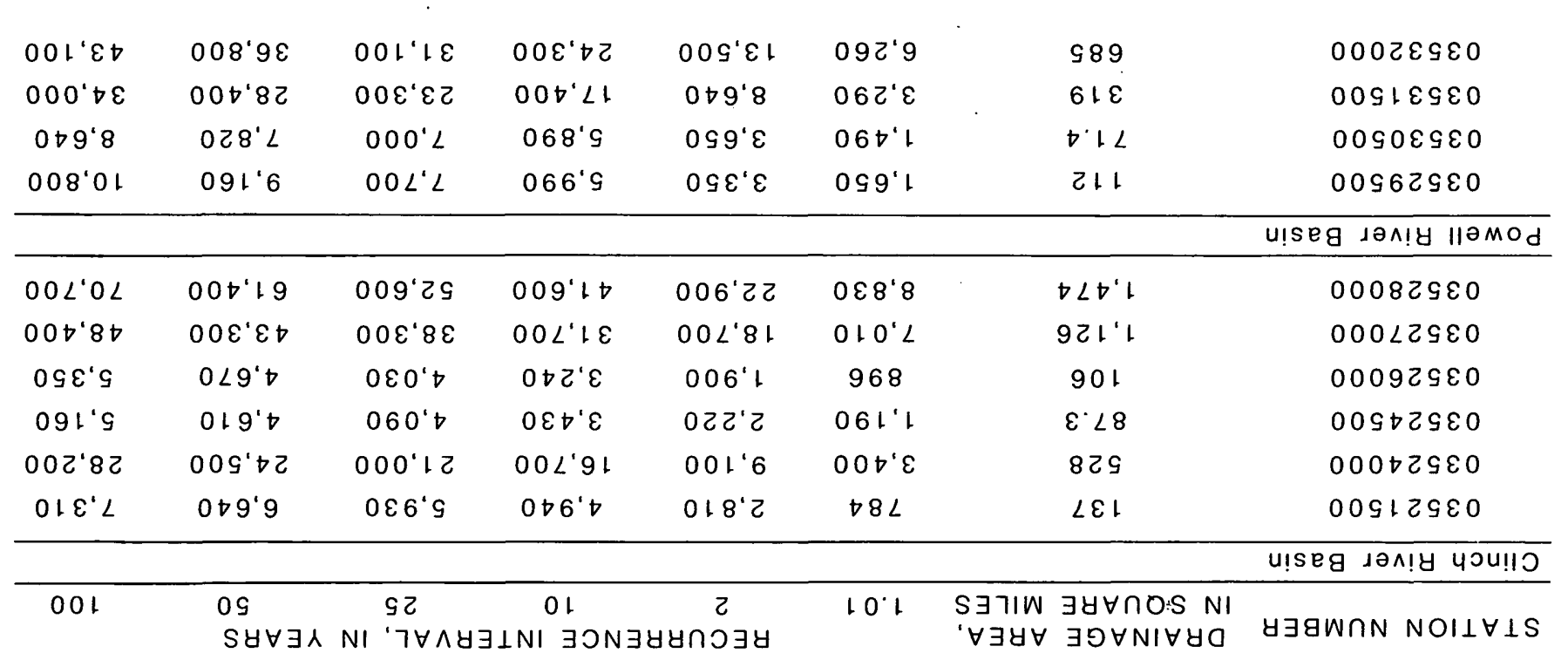




\title{
4.0 SURFACE WATER (Continued) \\ 4.5 DURATION OF FLOW
}

\section{FLOW DURATION SIMILAR FOR MAINSTEM CLINCH AND POWELL RIVER BASINS}

\author{
The flow-duration characteristics are similar for \\ the mainstems of both the Clinch and Powell River \\ basins. Tributary streams entering both rivers \\ from the west show significantly smaller unit \\ flows during base-flow periods than the tributary \\ streams entering from the east.
}

The time distribution of streamflow is illustrated by the flow-duration curve. The curves for selected rivers are shown in figures 4.5-1 and 4.5-2. Flowduration curves are based on the period of record at a site and show the percentage of time that a specific discharge can be expected to be equalled or exceeded. For example, a discharge of about $0.7\left(\mathrm{ft}^{3} / \mathrm{s}\right) / \mathrm{mi}^{2}$ at station number 03524500 (fig. 4.5-1) is expected to be equalled or exceeded about 50 percent of the time.

Hydrologic and geologic characteristics of a drainage basin are the principal factors that determine the shape of a duration curve. A curve that has a steep vertical slope represents highly variable streamflow, such as that from direct surface runoff. More gently sloping duration curves are characteristic of streams whose flow is augmented by delayed surface runoff and discharge from ground-water storage.

The time distribution of flows is generally similar in the mainstem portions of both the Clinch and Powell River basins of southwestern Virginia. Tribu- taries entering these rivers from the north and west (Guest River, 03524500, and North Fork Powell River, 03530500) show significantly smaller unit flows during baseflow periods than do tributaries entering from the south and east (Copper Creek, 03526000). During high-flow periods, the Guest River and the North Fork Powell River have slightly higher unit flows than Copper Creek. The areas to the north and west of the mainstems consist primarily of sandstones, shales, and coals, and have been mined extensively for the coal; areas to the east consist mostly of limestones and dolomites. Whether the differences in flow characteristics are due primarily to mining activities or to inherent differences in geology and physiography is uncertain.

Flow characteristics of streams are often summarized on a unit basis so that streams of varying drainage areas can be directly compared. However, the absolute values of these streamflow statistics are also useful in comparing relative quantities of flow. 
•u!seq jan!y llamod ayz u! uo!zesnp molf

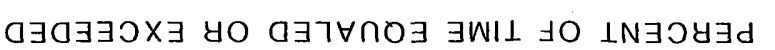

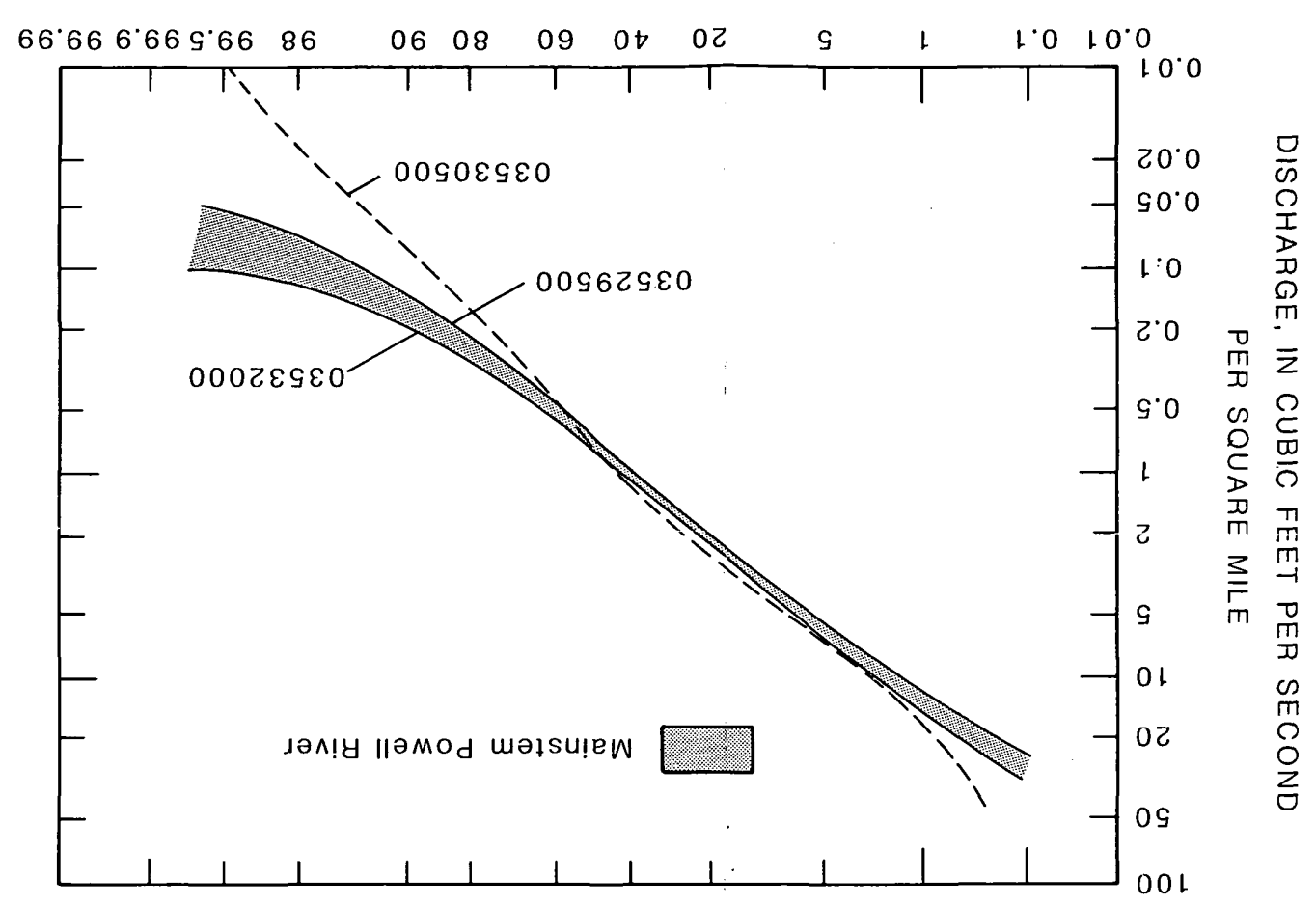

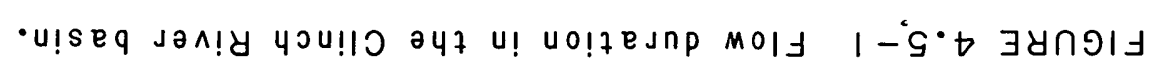

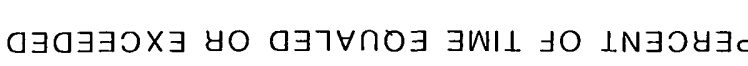

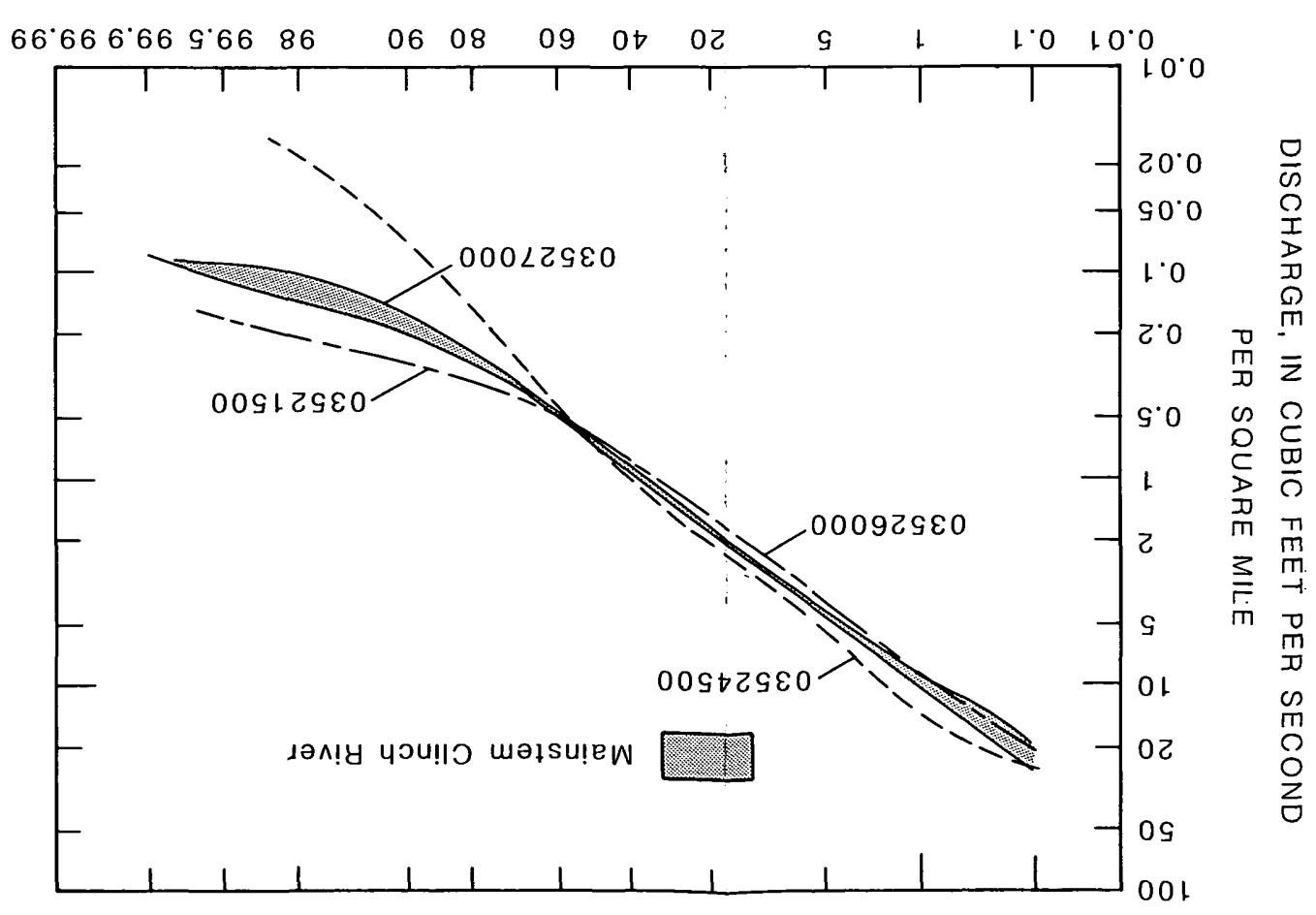

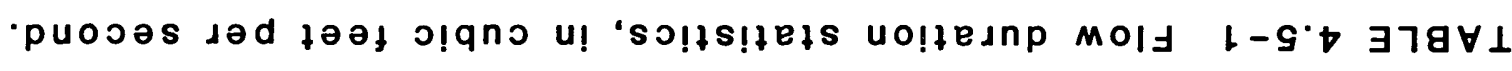

\begin{tabular}{|c|c|c|c|c|c|c|c|}
\hline $009^{\prime} z$ & $00 \varepsilon^{\prime} L$ & 069 & $0+2$ & $00 t$ & OLt & ५ 89 & $000 乙 \varepsilon \varsigma \varepsilon 0$ \\
\hline 00ट' & $06 \mathrm{~s}$ & $0 \triangleright \tau$ & 96 & os & $9 \varepsilon$ & $61 \varepsilon$ & $00 \varsigma \vdash \varepsilon \varsigma \varepsilon 0$ \\
\hline $0 乙 \varepsilon$ & $0+1$ & 89 & $9 \mathrm{l}$ & $1 \cdot 9$ & $s^{\cdot} \varepsilon$ & $0.1<$ & $00 \varsigma 0 \varepsilon \varsigma \varepsilon 0$ \\
\hline \multirow[t]{2}{*}{$09 t$} & $0 \varepsilon z$ & 26 & $\tau \varepsilon$ & $\angle t$ & 21 & 211 & $00 s 62 s \varepsilon 0$ \\
\hline & & & & & & & u!seg $12 \Lambda ! y\|\|_{0 M O}$ \\
\hline $008^{\prime} t$ & $00 \nabla^{\circ} \mathrm{Z}$ & 001.1 & $08 \mathrm{t}$ & $0<2$ & 012 & $\nabla<D^{\prime} 1$ & $0008 乙 ૬ \varepsilon 0$ \\
\hline $009^{\prime} \varepsilon$ & $006^{\circ} \mathrm{L}$ & $0 \varsigma 8$ & $0 \triangleright \varepsilon$ & 061 & ogt & $92 \downarrow$ ' & $000 \angle Z s \varepsilon 0$ \\
\hline $00 \varepsilon$ & 091 & $\varepsilon\llcorner$ & $8 \varepsilon$ & 82 & $\nabla z$ & 901. & $00092 \varsigma \varepsilon 0$ \\
\hline $0 \varepsilon \varepsilon$ & $09 \mathrm{t}$ & $\varepsilon 9$ & $6 t$ & $9 \cdot 9$ & $9^{\circ} \varepsilon$ & $\varepsilon^{*}<8$ & 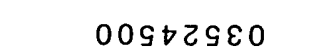 \\
\hline $009^{\prime}$ t & 018 & $08 \varepsilon$ & $0<1$ & 86 & $8 L$ & $82 \mathrm{~s}$ & $000 \downarrow 乙 \varsigma \varepsilon 0$ \\
\hline \multirow[t]{2}{*}{$02 \downarrow$} & 012 & 001 & $9 t$ & 62 & $\nabla 2$ & $\angle \varepsilon t$ & OOSı ZsEO \\
\hline & & & & & & & u!seg дәл!y чวu!। \\
\hline
\end{tabular}

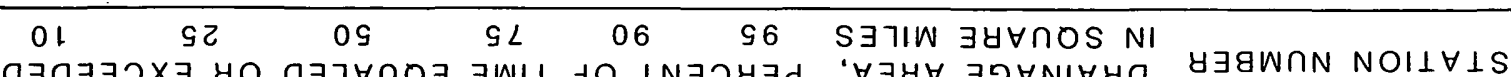




\title{
CALCIUM MAGNESIUM SULFATE TYPE WATER TYPIFIES STREAMS IN MINING AREAS
}

\author{
Calcium magnesium bicarbonate type water charac- \\ terizes most streams in Area 16. However, the \\ anion composition of the water changes from \\ bicarbonate to sulfate in areas affected by coal \\ mining.
}

The composition of a water can be conveniently presented in a trilinear diagram (Piper, 1944). In this diagram, the composition of a water is expressed by the percentages of total cations and anions. Water is classified by its dominant anion and cation groups. Thus, the water from station number 03524900 is of the calcium magnesium bicarbonate type.

Anions, such as chloride $\left(\mathrm{Cl}^{-}\right)$and sulfate $\left(\mathrm{SO}_{4}^{-}\right)$, and cations, such as calcium $\left(\mathrm{Ca}^{+}{ }^{+}\right)$and magnesium $\left(\mathrm{Mg}^{++}\right)$, arise from the dissolution of minerals by streams flowing over a particular rock type. Also minerals become dissolved in ground water that sustains streams during periods of low flow. Thus, the anion-cation composition of a water re- flects to some degree the minerals the stream has contacted.

Streams draining noncoal-bearing strata are generally of the calcium magnesium bicarbonate type. These streams are located along the east side of the Clinch and Powell River basins. Streams that drain the western flank of Area 16 flow primarily through coal-bearing strata. These latter streams come into contact with minerals that shift the anion composition toward sulfate. The Guest, Powell, and North Fork Powell Rivers all contain calcium magnesium sulfate type water. 


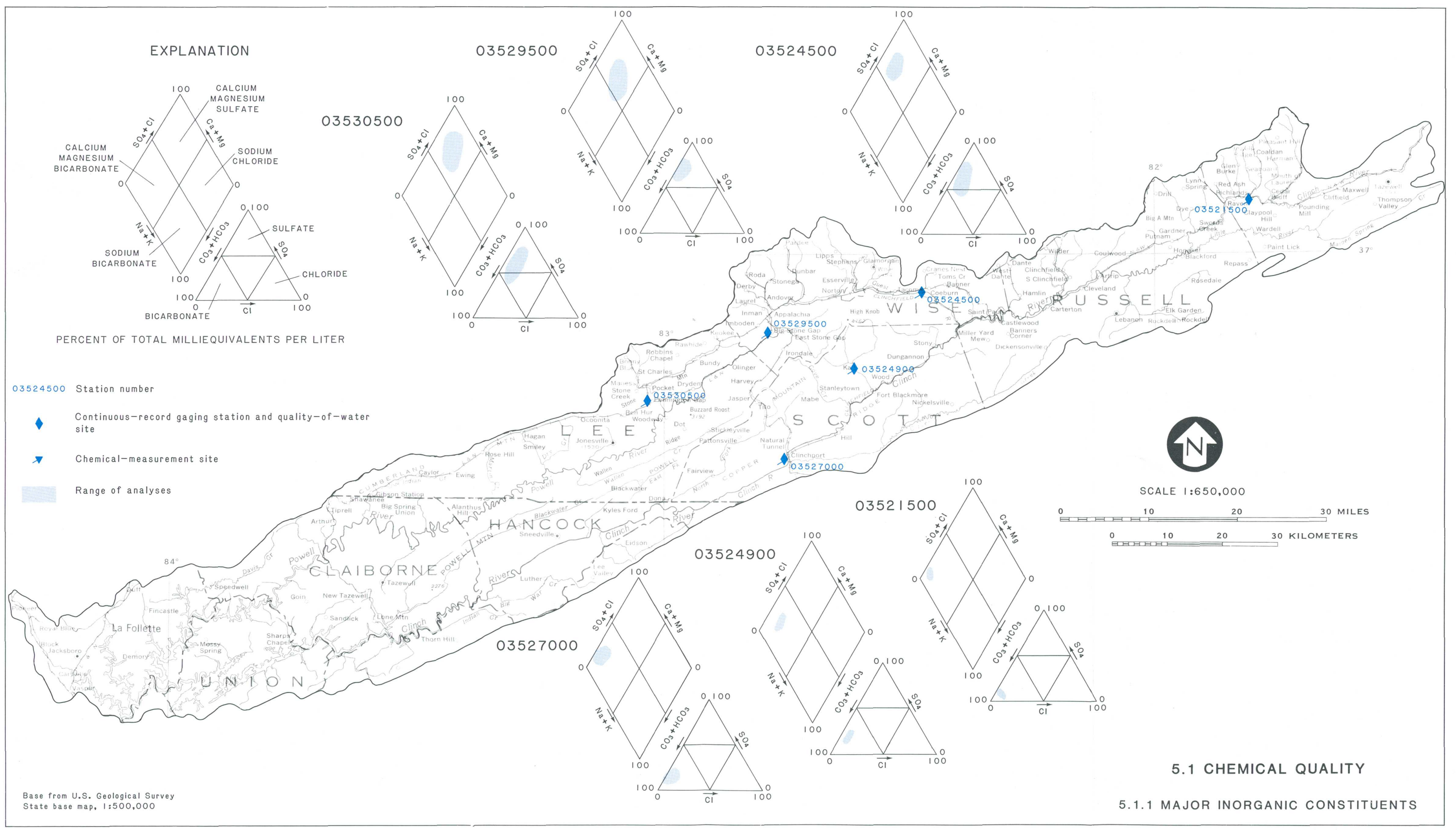




\title{
5.0 WATER QUALITY (Continued) \\ 5.1 CHEMICAL QUALITY (Continued) \\ 5.1.2 pH, ALKALINITY, ACIDITY
}

\section{pH, ALKALINITY, AND ACIDITY NOT SERIOUS PROBLEMS IN STREAMS SAMPLED}

\author{
$p H$, alkalinity, and acidity are not serious prob- \\ lems in the streams sampled in Area 16. Acid \\ and low pH problems occur locally, but dilution \\ and neutralization by calcareous materials improve \\ stream quality.
}

The $\mathrm{pH}$ of streams sampled in Area 16 ranges from $\mathrm{pH} 5.9$ to 10.4 . Minimum $\mathrm{pH}$ values were greater than $\mathrm{pH} 7$ in 47 percent of the streams sampled. The $\mathrm{pH}$ of streams draining mined basins ranged from $\mathrm{pH} 6.0$ to 10.4, compared to $\mathrm{pH}$ ranging from 5.9 to 8.7 in unmined basins. High $\mathrm{pH}$ values in many mined basins may result from extensive use of powdered limestone used for dust control in deep mines.

Alkalinity is a measure of the capacity of a water to neutralize an acid solution. Alkalinity in a natural water is due primarily to the presence of carbonates and bicarbonates. Alkalinity measurements in Area 16 ranged from 0 to 430 milligrams per liter as calcium carbonate $\left(\mathrm{mg} / \mathrm{L}\right.$ as $\left.\mathrm{CaCO}_{3}\right)$. The mean alkalini- ty in mined basins was $63 \mathrm{mg} / \mathrm{L}$ as $\mathrm{CaCO}_{3}$ compared to $61 \mathrm{mg} / \mathrm{L}$ as $\mathrm{CaCO}_{3}$ in unmined basins.

Acidity is a measure of the capacity of a water to neutralize a basic solution. Acidity in a natural water is due primarily to the presence of hydrolyzable metal ions. Acidity measurements in Area 16 ranged from 0 to $124 \mathrm{mg} / \mathrm{L}$ as $\mathrm{CaCO}_{3}$. The mean acidity in mined basins is $6.2 \mathrm{mg} / \mathrm{L}$ as $\mathrm{CaCO}_{3}$ which is not significantly different from the mean acidity of $6.1 \mathrm{mg} / \mathrm{L}$ as $\mathrm{CaCO}_{3}$ in unmined basins.

Table 5.1.2-1 shows the range and mean concentration of alkalinity and acidity for selected stations in Area 16. 


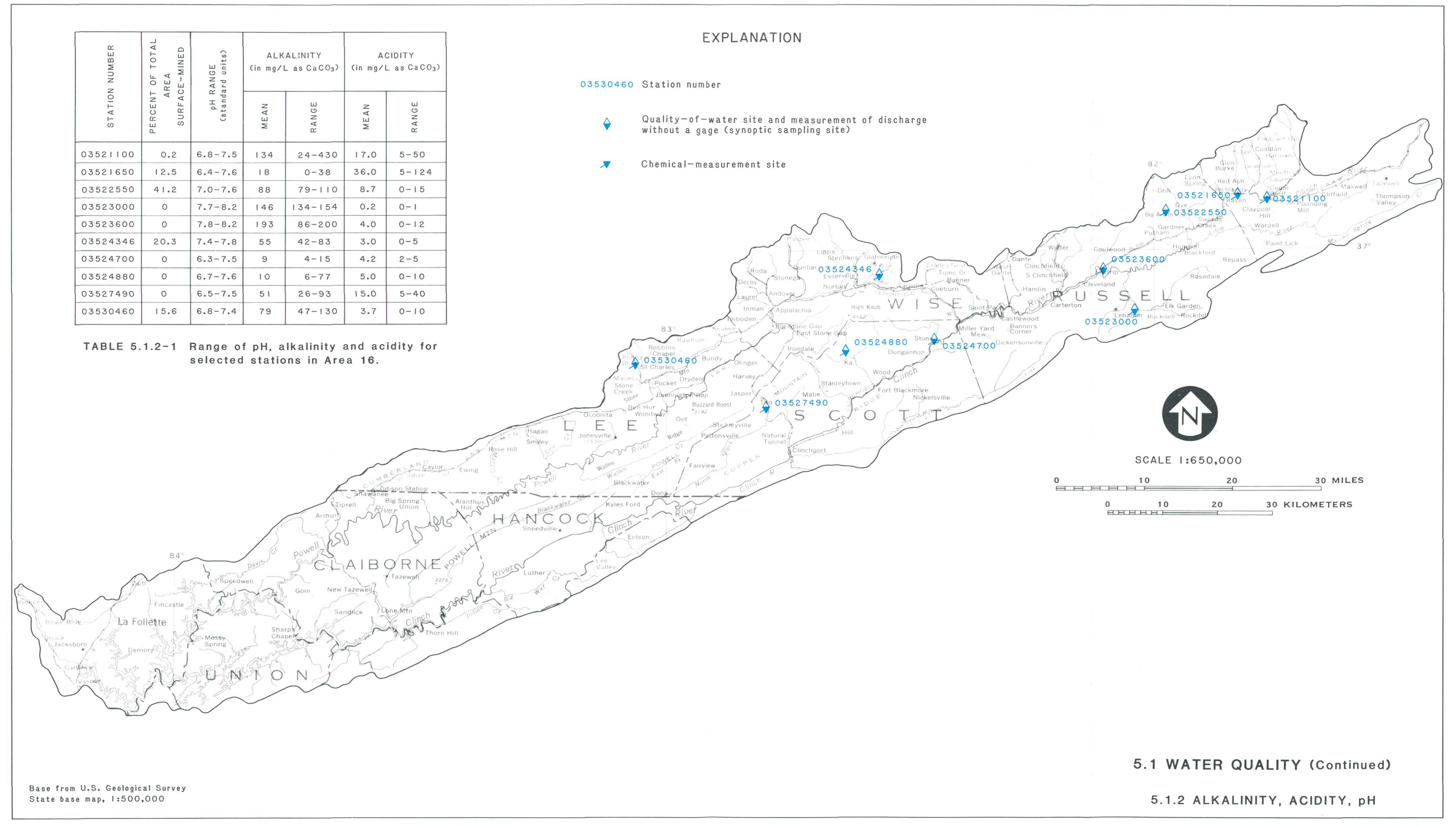




\title{
5.0 WATER QUALITY (Continued) \\ 5.1 CHEMICAL QUALITY (Continued) \\ 5.1.3 CONDUCTANCE, DISSOLVED SOLIDS
}

\section{DISSOLVED-SOLIDS CONCENTRATIONS HIGH IN MINED AREAS}

\author{
Both specific conductance and dissolved-solids \\ concentrations are higher in mined basins than \\ in unmined basins. The dissolved-solids con- \\ centration ranges from 10 to 200 milligrams \\ per liter ( $\mathrm{mg} / \mathrm{L}$ ) in unmined basins compared to \\ a range of 50 to $600 \mathrm{mg} / \mathrm{L}$ in mined basins.
}

Specific conductance, expressed in micromhos per centimeter at $25^{\circ} \mathrm{C}\left(\mu \mathrm{mho} / \mathrm{cm} @ 25^{\circ} \mathrm{C}\right)$, is a measure of the ability of a water to conduct an electrical current. The presence of charged ionic species causes the water to conduct electricity. As the concentration of ions increases, the conductance of the solution increases.

Dissolved solids, expressed in milligrams per liter $(\mathrm{mg} / \mathrm{L})$, is a measure of the total concentration of dissolved material in a water sample, determined from the weight of the dry residue remaining after evaporation. The dry residue is composed mostly of the salts and hydrates of ions that were dissolved in the water sample.

Because the specific conductance is related to the quantity and type of ions dissolved in a water sample, it can be used as a general indication of the dissolved-solids concentration. Commonly, the factor relating specific conductance to dissolved solids is about 0.65 . However, this factor can range from 0.54 to $0.96(\mathrm{Hem}, 1970)$, and thus must be used with care when predicting dissolved-solids concentration from specific conductance values. It is important to limit such predictions to areas where previous work has been conducted and for which the empirical rela- tionship between specific conductance and dissolved solids has been defined. Especially important to this relationship are the chemical analyses defining the exact ionic composition.

In area 16 , the factor relating specific conductance to dissolved solids is 0.70 in mined basins and 0.54 in unmined basins. This difference may be caused by effects of increased sulfate loading in mined basins. The map shows mean dissolved-solids concentration for subbasins of the study area. In general, streams in areas known to be unmined have conductances ranging from 10 to $300 \mu \mathrm{mho} / \mathrm{cm} @$ $25^{\circ} \mathrm{C}$ and dissolved-solids concentrations ranging from 10 to $200 \mathrm{mg} / \mathrm{L}$. In areas known to have extensive surface-mining activity, streams have specific conductances ranging from 80 to $800 \mu \mathrm{mho} / \mathrm{cm} @$ $25^{\circ} \mathrm{C}$ and dissolved solids ranging from 50 to 600 $\mathrm{mg} / \mathrm{L}$. Seasonal variation in specific conductance and dissolved solids occurs due to dilution from rainwater. In general, the lowest dissolved-solids concentration and specific conductance values occur during the high-flow periods of late winter and spring, and the highest specific conductances and dissolved-solids concentrations occur during low-flow periods. 


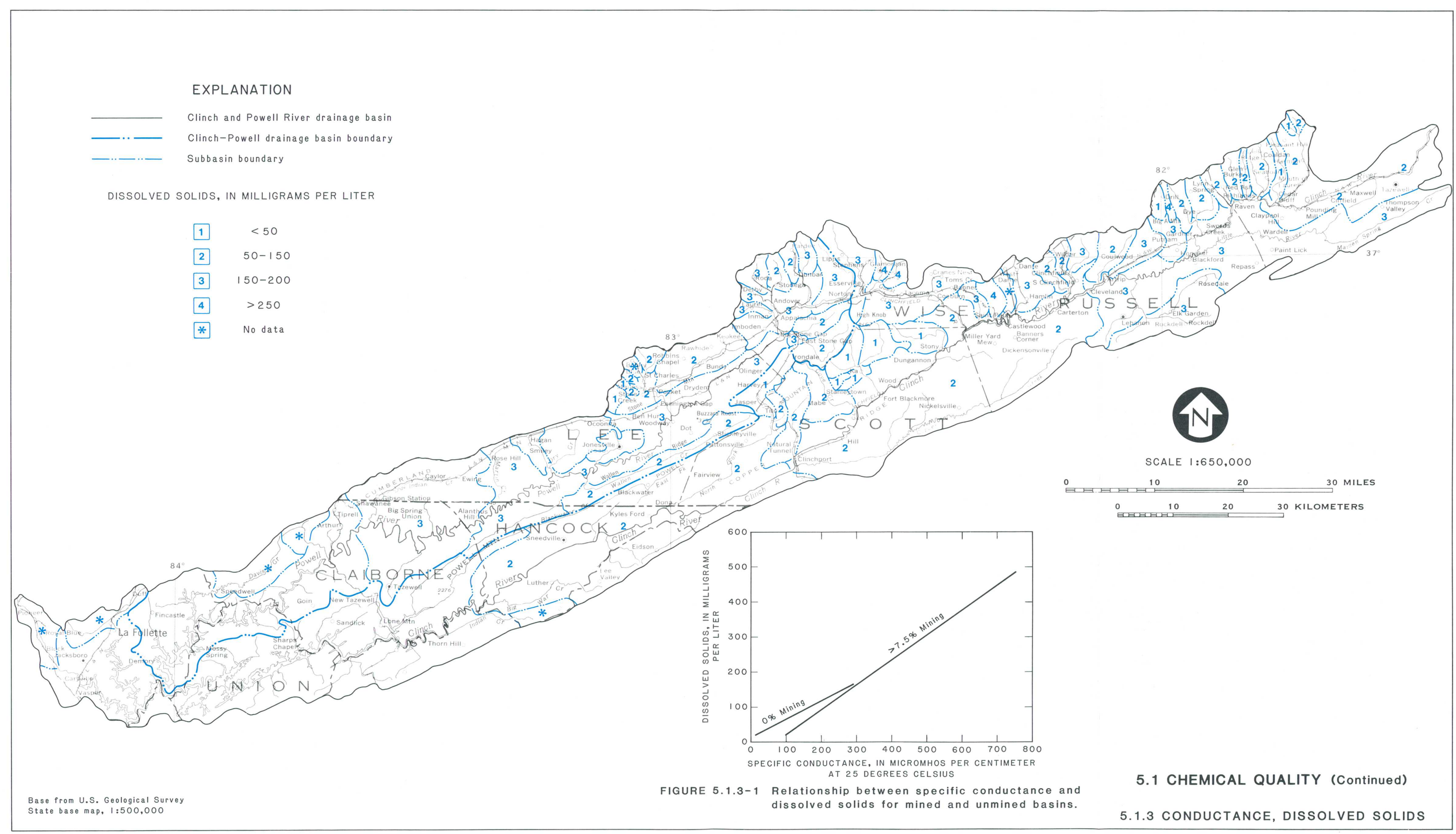




\title{
5.0 WATER QUALITY (Continued) \\ 5.1 CHEMICAL QUALITY (Continued) \\ 5.1.4 SULFATE LOADING
}

\section{SULFATE LOADINGS ARE HIGH IN STREAMS DRAINING MINED AREAS}

\author{
Area-weighted sulfate loadings were calculated \\ for the subbasins of Area 16. The greatest \\ loadings occurred in areas with extensive mining. \\ The Clinch River shows the impact of increased \\ downstream sulfate loading from tributaries \\ draining mined areas.
}

Area-weighted sulfate loadings are calculated using dissolved-sulfate concentration in milligrams per liter $(\mathrm{mg} / \mathrm{L})$, streamflow, in cubic feet per second $\left(\mathrm{ft}^{3} / \mathrm{s}\right)$, and drainage basin area, in square miles $\left(\mathrm{mi}^{2}\right)$. The resulting units of sulfate loading are pounds per day per square mile $\left([\mathrm{lb} / \mathrm{d}] / \mathrm{mi}^{2}\right)$. Loadings are used rather than concentrations because loadings take into account differences in concentration due to varying streamflow. Furthermore, area weighting of the loadings allows direct comparison of large and small drainage basins.

The sulfate loading of the unmined areas of the Clinch and Powell River basins is generally less than $45[\mathrm{lb} / \mathrm{d}] / \mathrm{mi}^{2}$. Mined areas along the west flank of Area 16 have sulfate loading commonly exceeding $150[\mathrm{lb} / \mathrm{d}] / \mathrm{mi}^{2}$. The highest sulfate loadings occur during periods of high streamflow, although the absolute sulfate concentrations may be quite low. The highest concentrations of sulfate occur during lowflow periods when there is little dilution from rainfall, and the water has longer contact time with spoil areas and overburden.

Sulfate loading has increased in the Clinch and
Powell River basins since 1930. The mean sulfate loading of $525[\mathrm{lb} / \mathrm{d}] / \mathrm{mi}^{2}$ in 1930 has increased to more than $900[\mathrm{lb} / \mathrm{d}] / \mathrm{mi}^{2}$ in 1979 (Rogers and Hufschmidt, 1980).

Sulfate is produced by the oxidation and weathering of the iron-bearing minerals pyrite and marcasite in an aqueous environment. Both pyrite and marcasite are present in coal beds. Crystals of pyrite are commonly found in black shales and bituminous sandstones (Krauskopf, 1967). The variation in sulfate production is controlled by many factors, including: (1) the nature of local geology and reactive minerals, (2) the contact time and neutralization reactions, and (3) the amount of water available for reaction with the sulfur-bearing minerals.

There are significant correlations among surface-mining activity and specific conductance and sulfate concentrations. These water-quality parameters are generally highest for those basins that are extensively mined and lowest in those basins that have little or no mining activity. 


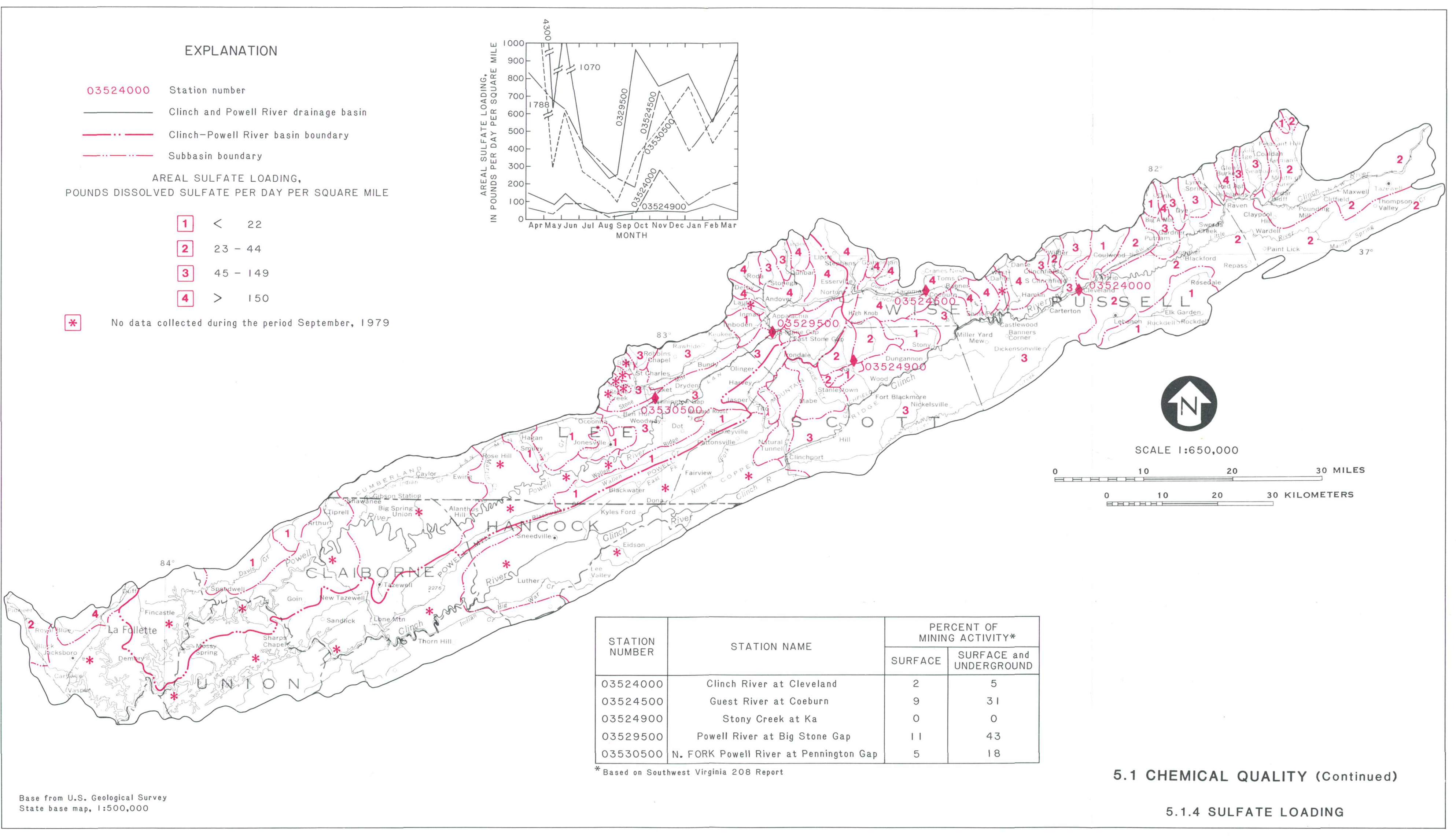




\title{
5.0 WATER QUALITY (Continued) \\ 5.1 CHEMICAL QUALITY (Continued) \\ 5.1.5 DISSOLVEDIRON
}

\section{DISSOLVED-IRON CONCENTRATIONS ARE HIGHLY VARIABLE IN AREA 16}

\author{
Dissolved-iron concentrations ranged from 0 to \\ 1,900 micrograms per liter in Area 16. Sites \\ in mined areas generally had higher minimum \\ concentrations than unmined sites. However, \\ in several instances, the dissolved-iron con- \\ centration was greater in unmined basins than \\ in mined basins.
}

The concentration of dissolved iron is of concern for several reasons. Dissolved iron in excess of 300 micrograms per liter $(\mu \mathrm{g} / \mathrm{L})$ imparts objectionable taste, may cause staining, and render the water unfit for many industrial and domestic supplies. Background concentrations of iron in water arise from iron associated with soils and minerals. High concentrations of iron in Area 16 originate through the weathering and solution of pyrite and marcasite associated with coal, and hematite associated with Clinton iron ore. Dissolved-iron concentrations in undisturbed basins generally range from 9 to 150 $\mu \mathrm{g} / \mathrm{L}$. In mined basins, the dissolved-iron concentrations were higher than in unmined basins and ranged from 10 to $300 \mu \mathrm{g} / \mathrm{L}$.

Figure 5.2.5-1 shows the ranges and mean values of dissolved-iron concentrations in selected mined and unmined basins. The mined and unmined basins have similar distributions of dissolved-iron concentrations. Although the minimum concentration of dissolved iron is generally higher in mined basins, several unmined basins have higher mean and maximum dissolved-iron concentrations than mined basins.

Several factors control the solubility of iron, the most important of which are $\mathrm{pH}$, dissolved oxygen, dissolved carbon dioxide, and sulfur. Insoluble iron precipitates are formed through oxygenation of mine drainage that has high concentrations of dissolved iron. Precipitates also form when mine drainage mixes with streams of higher $\mathrm{pH}$. Iron precipitates are strongly attracted to sediment particles and can coat stream beds. During periods of high flow, these sediment particles and iron precipitates are scoured from the stream beds, resulting in high concentrations of total iron. Figure 5.1.5-2 shows the relationship between the concentrations of suspended sediment and total iron. 


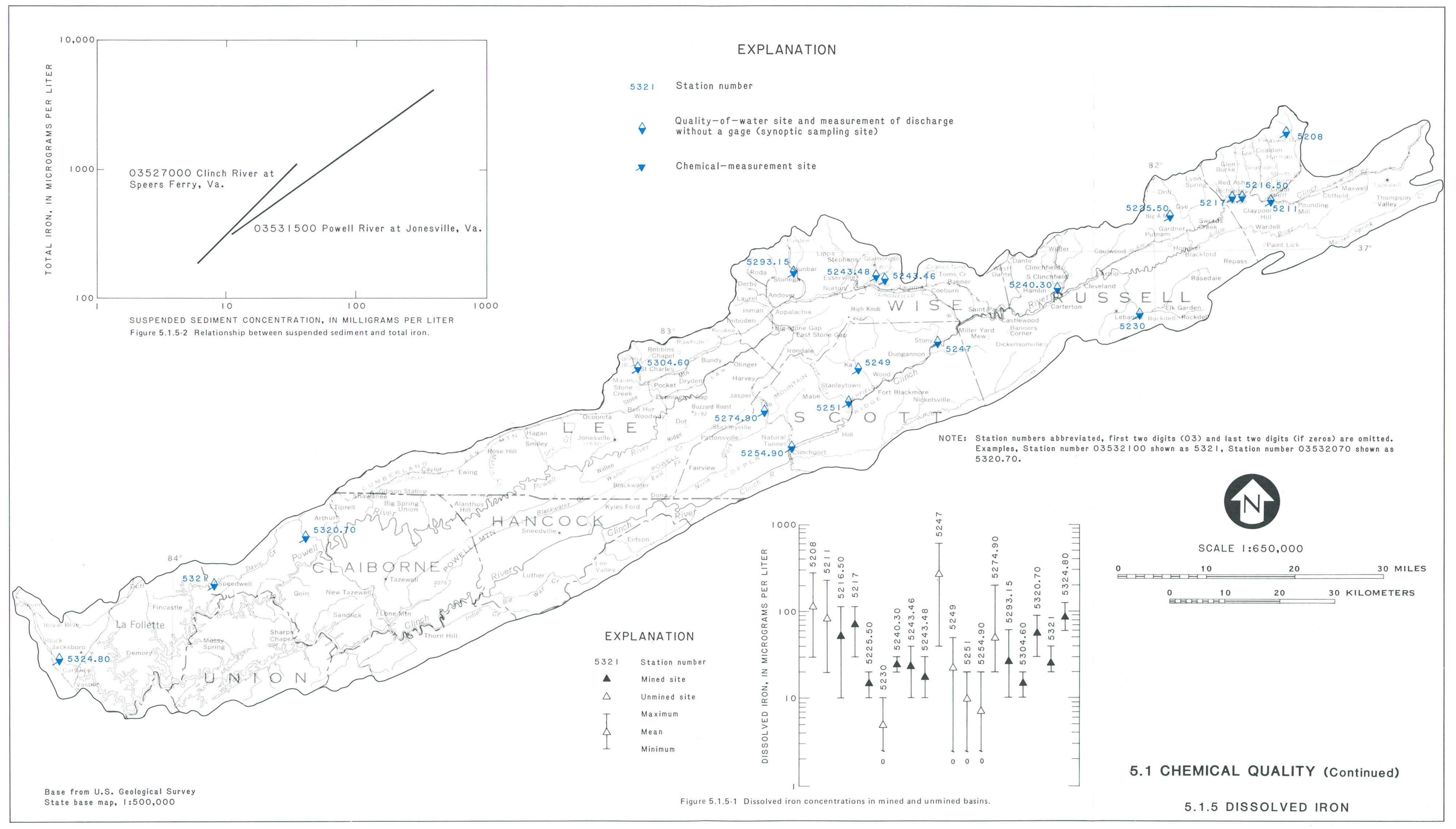




\title{
DISSOLVED-MANGANESE CONCENTRATIONS ARE HIGHLY VARIABLE IN AREA 16
}

\author{
Dissolved-manganese concentrations ranged from \\ 9 to 1,100 micrograms per liter $(\mu \mathrm{g} / \mathrm{L})$ in Area \\ 16. Dissolved-manganese concentrations in mined \\ areas averaged $108 \mu \mathrm{g} / \mathrm{L}$ while the concentration \\ in unmined areas averaged $10 \mu \mathrm{g} / \mathrm{L}$.
}

\begin{abstract}
The concentration of dissolved manganese is of concern for several reasons. Dissolved manganese in excess of 50 micrograms per liter $(\mu \mathrm{g} / \mathrm{L})$ imparts objectionable taste, may cause staining, and generally renders water unfit for many industrial and domestic supplies. These effects are similar to those of iron because the two metals react similarly. Background concentrations in water arise from manganese associated with soils and minerals. High concentrations of manganese in Area 16 originate through the weathering of overburden associated with coal and other manganese-bearing deposits. Dissolvedmanganese concentrations in undisturbed areas generally range from 0 to $160 \mu \mathrm{g} / \mathrm{L}$ and average $10 \mu \mathrm{g} / \mathrm{L}$. The dissolved-manganese concentration in mined areas range from 0 to $1,100 \mu \mathrm{g} / \mathrm{L}$ with an average concentration of $110 \mu \mathrm{g} / \mathrm{L}$.
\end{abstract}

Figure 5.1.6-1 shows the ranges and mean values of dissolved-manganese concentrations in selected mined and unmined basins. Mined basins generally have higher mean and maximum concentration than unmined basins. However, there is some overlap in the distribution, possibly related to local manganese deposits.

The factors controlling the solubility of manganese are highly complex and a discussion of them is beyond the scope of this report. However, it is important to note that "one of the notable properties of manganese oxide is a tendency to form coatings on other mineral surfaces..." (Hem, 1970); thus, manganese is often sorbed to suspended-sediment particles. Figure 5.1.6-2 shows the relationship between suspended sediment and total manganese. 


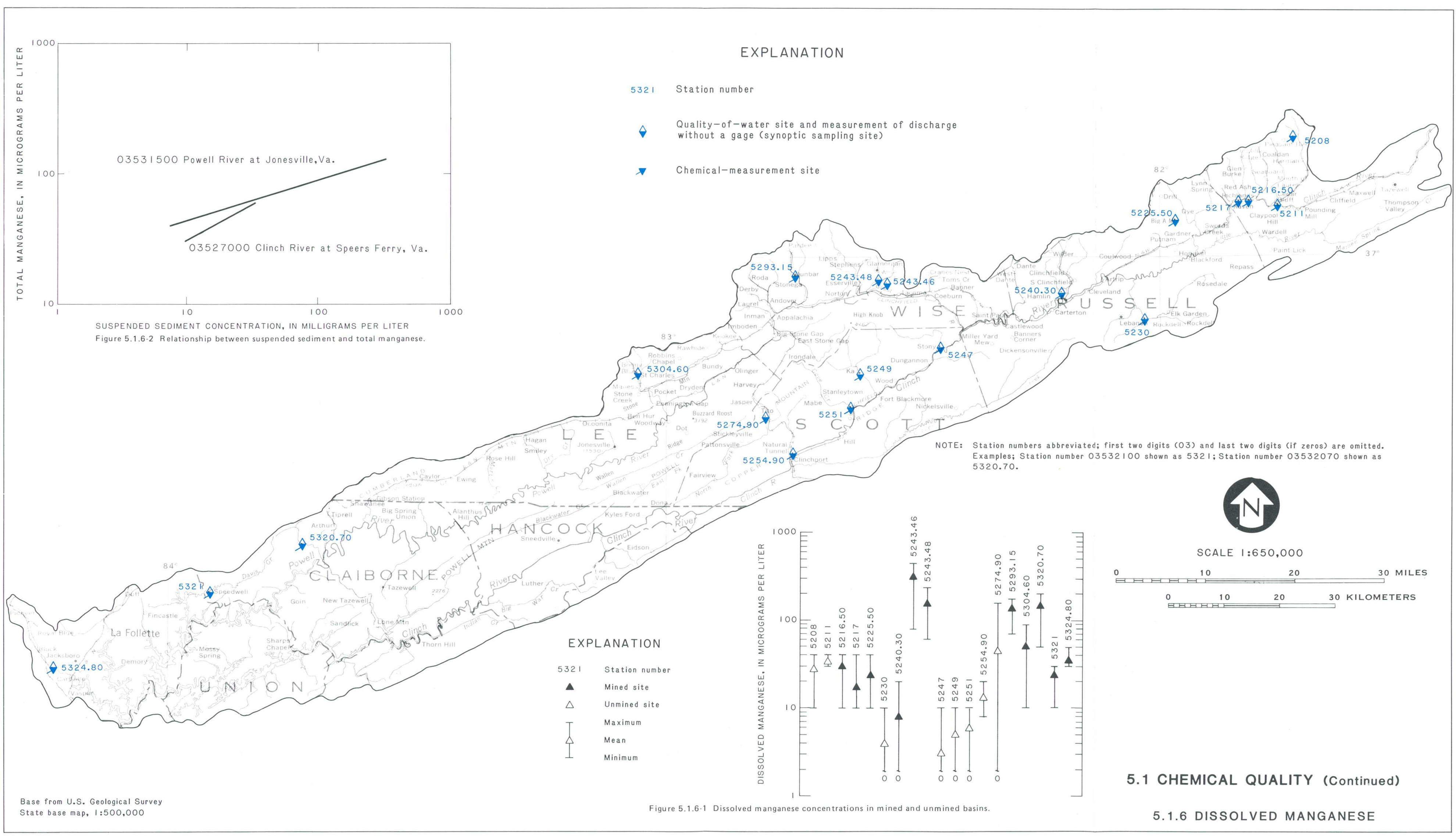




\title{
SAMPLES FROM 16 STATIONS IN AREA 16 EXCEED QUALITY CRITERIA FOR DISSOLVED IRON AND MANGANESE
}

\author{
Water samples from 16 stations in the Guest and \\ Powell River basins of Area 16 exceeded quality \\ criteria for iron and manganese. Dissolved iron \\ and manganese quality criteria are set at 1,000 \\ and 200 micrograms per liter $(\mu \mathrm{g} / \mathrm{L})$, respectively.
}

The map on the facing page shows the location of stations in Area 16 where concentrations of dissolved iron and manganese have exceeded specified alert limits.

The alert limit for iron is set at $1,000 \mu \mathrm{g} / \mathrm{L}$ for the adequate protection of freshwater aquatic life, based on recommendations in Water Quality Criteria, U.S. Environmental Protection Agency, 1976. The U.S. E.P.A. recommends that dissolved manganese should not exceed $50 \mu \mathrm{g} / \mathrm{L}$ for domestic water supplies. Constituents such as iron and manganese, however, commonly occur naturally in concentrations that exceed the most stringent criteria, and setting limiting values too low would result in flagging a large fraction of the analytical values for these constituents. Therefore, the alert limits for iron and manganese are somewhat arbitrarily set at 1,000 and $200 \mu \mathrm{g} / \mathrm{L}$, respectively.

As dissolved metals, both iron and manganese are colorless and impart taste in concentrations in excess of 300 and $50 \mu \mathrm{g} / \mathrm{L}$, respectively. Both metals oxidize upon contact with air to form black (manganese) and red (iron) colored precipitates that cause staining problems. 
295 Station number

- Continuous-record gaging station and quality-of-water site

$\triangle \quad$ Quality-of-water site and measurement of discharge without

- Chemical neasurent site

Mn Site where dissolved manganese concentration has exceeded

$\mathrm{Fe} \quad$ Site where dissolved iron concentration has exceeded
1000 micrograms per liter NOTE: Station numbers abbreviated, first two digits (03) and last two digits (if zeros) are omitted.
Exampless; 5 tation number 03529500 shown as 5295 ; Station number 03530460 shown as
5304,60 .
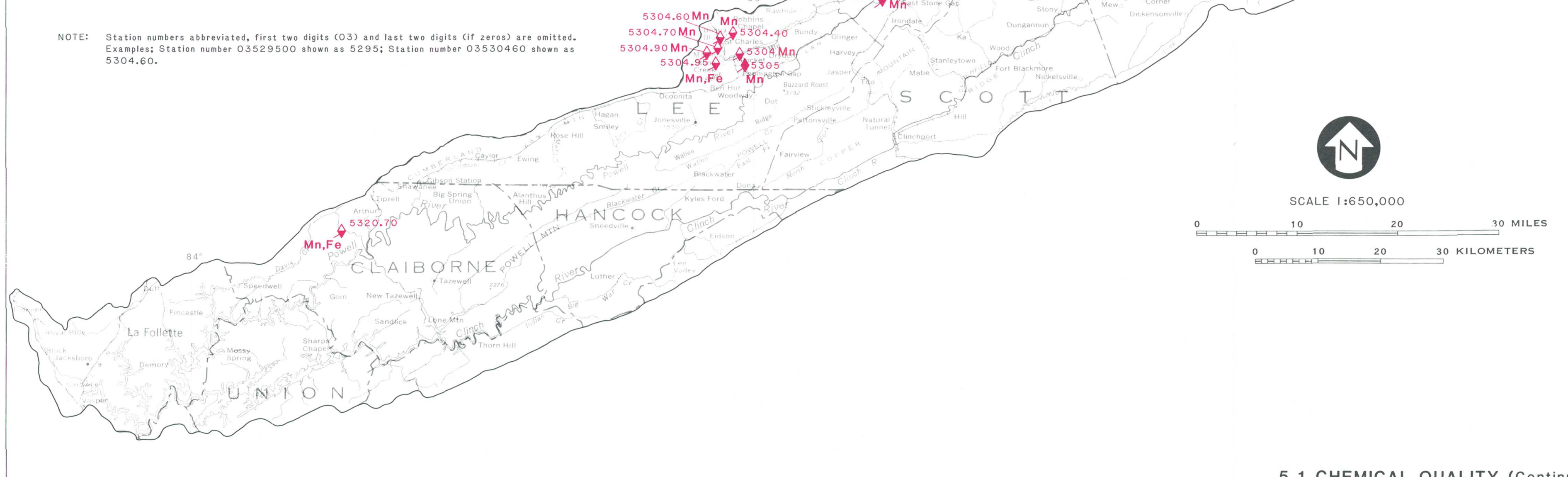


\title{
5.0 WATER QUALITY (Continued) \\ 5.1 CHEMICAL QUALITY (Continued) \\ 5.1.8 METALS IN BOTTOM SEDIMENTS
}

\section{METALS ACCUMULATE IN BOTTOM SEDIMENTS}

\author{
The metals in bottom sediments originate from \\ weathering and erosion of minerals in the water- \\ shed. Evaluation of the metals concentration in \\ bottom sediments helps in understanding the \\ concentration of metals in streams.
}

During the summer of 1979,21 bottom sediment samples were collected to assess the distribution of metals in Area 16. Bottom sediments act as metal accumulators because trace metals associate strongly with particulate materials. Sampling sites were chosen throughout Area 16 to represent differing land use and geology.

The metals associated with bottom sediments are derived primarily by weathering and erosion of material within the watershed. Besides the natural background content of metals due to local geology, other possible sources of metals in the area include active and inactive mines, municipal discharges, and industrial activities. Because there are few large population centers in Area 16, "urban runoff" is not a significant source of metals.

Samples were analyzed for the following metals: Arsenic (As), Cadmium (Cd), Chromium (Cr), Cobalt $(\mathrm{Co})$, Copper $(\mathrm{Cu})$, Lead $(\mathrm{Pb})$, Mercury $(\mathrm{Hg})$, Selenium (Se), Zinc ( $\mathrm{Zn})$, Iron ( $\mathrm{Fe})$, and Manganese $(\mathrm{Mn})$. Information is scant regarding the background concentration of these metals; however, se- veral deposits of iron, manganese, lead, and zinc are known in Area 16. Care must be exercised in attributing high metal concentrations to mining when the background concentration of a particular metal may be relatively high.

Clinton iron ore crops out along the border between Virginia and Kentucky in Lee and Wise Counties (Gooch, 1964). Mining for iron was active in Virginia between 1825 and 1900, and in Tennessee between 1820 and 1960. The ore ranges from 26 to 40 percent iron. The presence of the Clinton iron ore probably causes the high concentration of iron in the bottom sediments, especially around Pennington Gap, Virginia, and La Follette, Tennessee.

Small manganese deposits in Area 16 occur in residual clay derived from the weathering of crystalline schist or sandstone. The manganese deposits in sandstone, locally associated with iron ore (McGill, 1936), may be the source for the high concentrations of iron and manganese in bottom sediments. 


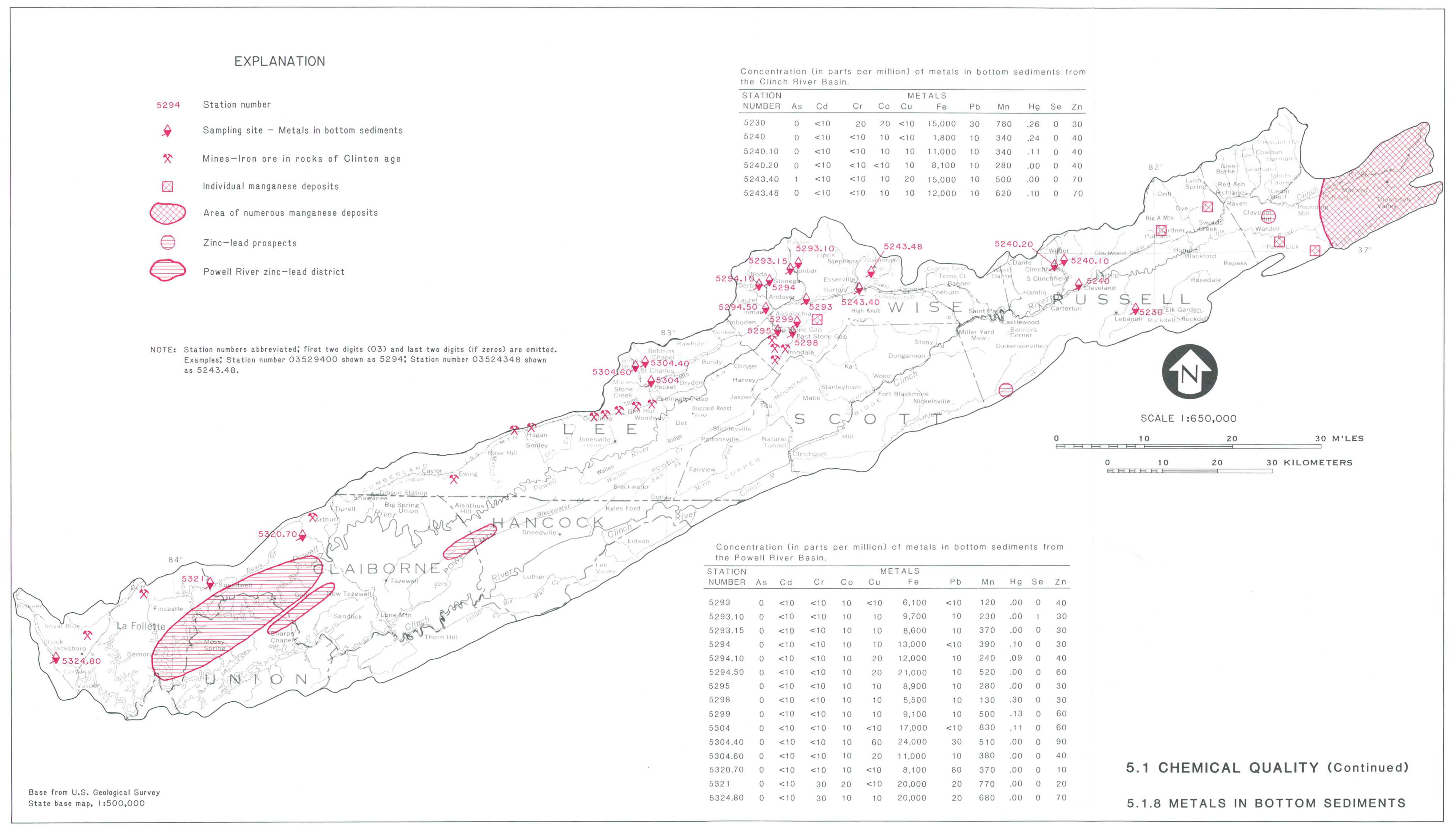




\title{
5.0 WATER QUALITY (Continued) \\ 5.1 CHEMICAL QUALITY (Continued) \\ 5.1.9 TRACE METALS
}

\section{TRACE METAL CONCENTRATIONS LOW IN AREA 16}

\author{
Trace metal concentrations in Area 16 are low and generally \\ fall below health and water-quality standards.
}

Trace metals occur naturally in soils and rocks. Low concentrations of these metals are common in most waters. Anomalously high concentrations can occur naturally; however, such high concentrations of trace metals usually occur due to waste discharge.
Trace metal concentrations measured in Area 16 were all below the U.S. Environmental Protection Agency recommended limits (1977) and are shown in figure 5.1.9-1. 


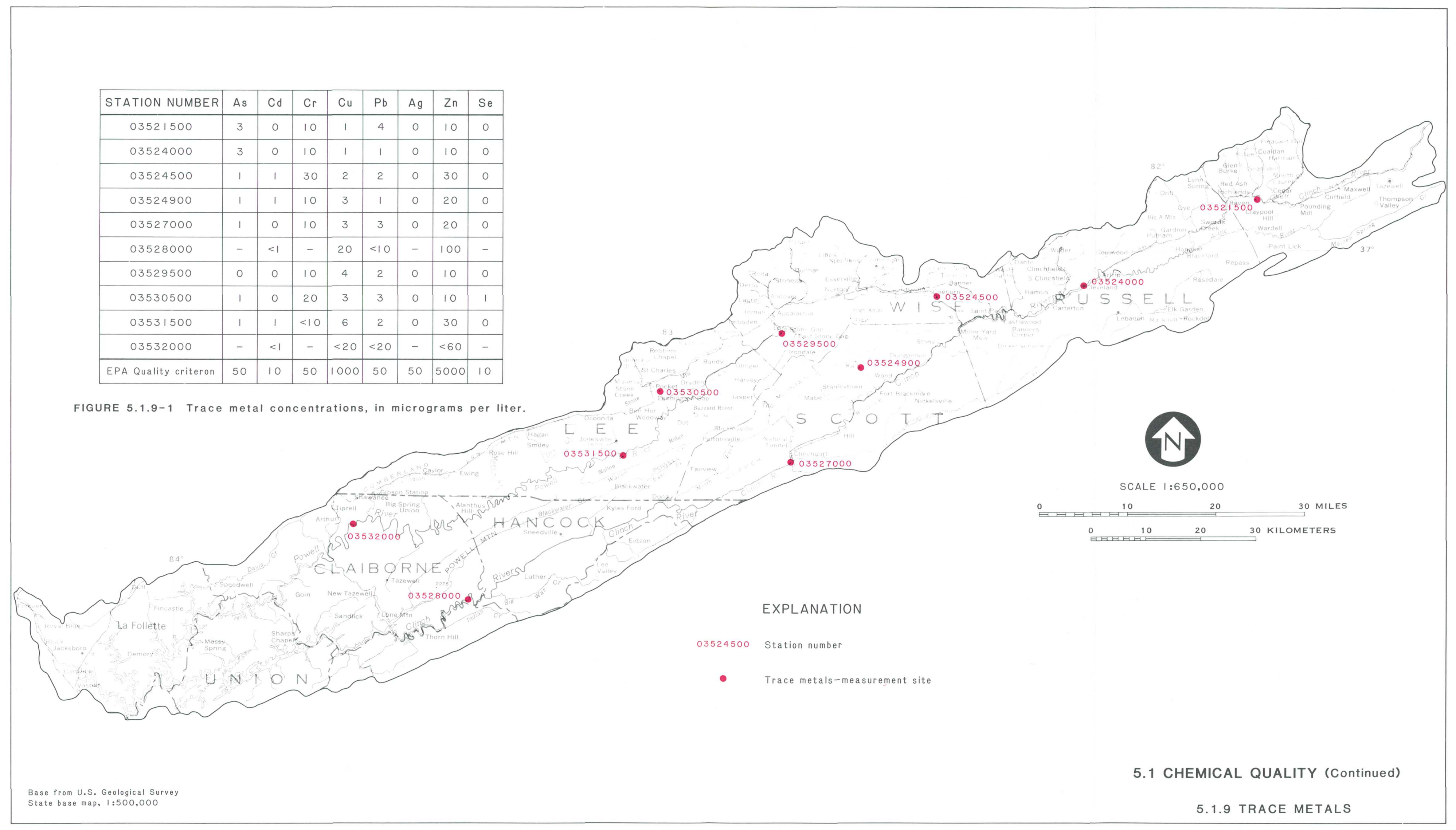




\title{
5.0 WATER QUALITY (Continued) \\ 5.2 SUSPENDED SEDIMENT
}

\section{SUSPENDED-SEDIMENT LOADINGS ARE HIGHLY VARIABLE IN AREA 16}

\author{
Suspended-sediment concentrations as high as 1,030 \\ milligrams per liter have been measured in Area 16.
}

Activities that commonly result in high sediment yield include mining, construction, agriculture, and forestry. Agricultural activities alone result in over 50 percent of all sediment delivered to streams and lakes in the United States (U.S. EPA, 1976). Surfacemining activities, such as land clearing, road building, and refuse piles also contribute significantly to increased sediment loading. Factors influencing the rate of sediment production include soil type, slope, duration and intensity of rainfall, and vegetative cover.

Suspended-sediment concentrations measured in
Area 16 ranged from 1 milligram per liter $(\mathrm{mg} / \mathrm{L})$ to greater than $500 \mathrm{mg} / \mathrm{L}$. There is insufficient data, at this time, to predict annual sediment loadings in mined and unmined basins.

The figure shows the relationship between sediment yield and stream discharge for unmined and mined basins. Although the slope of the lines is based on limited amounts of data, the data for these two stations show that more sediment is discharged in streams draining surface-mined areas. 


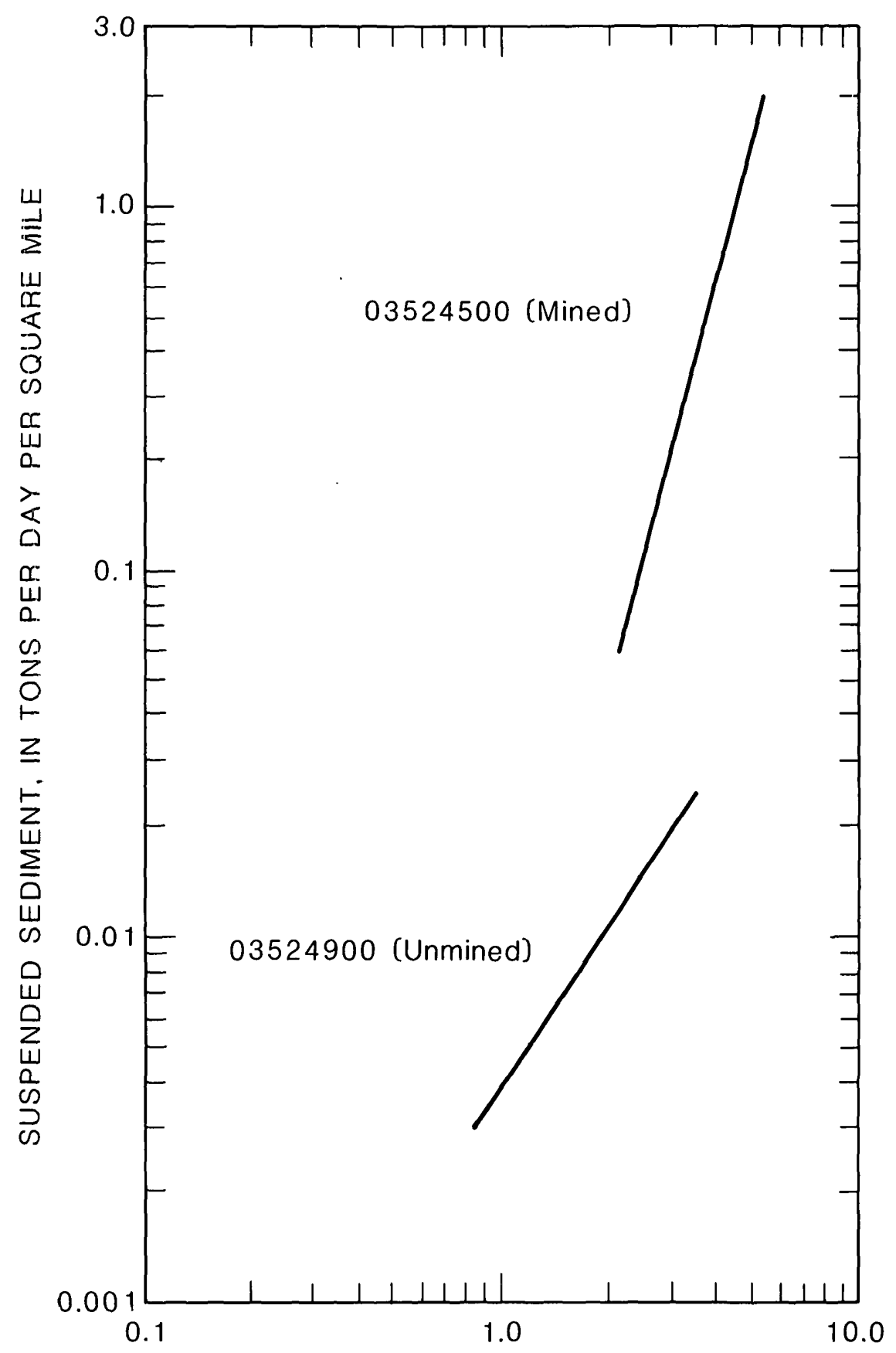

STREAM DISCHARGE, IN CUBIC FEET PER SECOND PER SQUARE MILE

\begin{tabular}{|c|c|c|}
\hline & \multicolumn{2}{|c|}{ STATION NUMBER } \\
\hline & 03524500 & 035249.00 \\
\hline Period of record & $1979-1980$ & $1979-1980$ \\
\hline $\begin{array}{l}\text { Suspended sediment concentration } \\
\text { range, } \mathrm{mg} / \mathrm{L}\end{array}$ & $34-1030$ & $<1-7$ \\
\hline Drainage area, $\mathrm{mi}^{2}$ & 87.3 & 30.9 \\
\hline Percent of basin mined & 9 & unmined \\
\hline
\end{tabular}

FIGURE 5.2-1 Suspended sediment concentration versus discharge for mined and unmined sites in Area 16.

5.0 WATER QUALITY (Continued)

5.2 SUSPENDED SEDIMENT 


\title{
5.0 WATER QUALITY (Continued)
}

5.3 BENTHIC INVERTEBRATES

\section{BENTHIC INVERTEBRATES ARE INDICATORS OF STREAM QUALITY}

\author{
Overall stream quality is reflected by the \\ community structure of benthic invertebrates. \\ Good quality streams have numerous taxa repre- \\ sented with few organisms per group.
}

Fourteen streams were sampled for community structure of benthic invertebrates during the lowflow period of September 1979. Organisms were found to inhabit all streams sampled.

The community structure of benthic invertebrates can be a good indicator of stream quality. The organisms in a stream must survive changes that take place in the stream. These changes include fluctuation in streamflow, temperature, dissolved oxygen, chemical quality, and sediment concentration. Any organism intolerant of these variations will not survive. Generally, in a highly stressed environment, only the hardiest organisms survive, resulting in a very homogeneous community structure. Clean, undisturbed environments usually have many taxa represented, but few individuals per taxon.

The community structure of streams sampled during September 1979 indicated good biological quality (table 5.3-1). However, the sites sampled were far downstream of most mining activity, and dilution-neutralization of mine drainage could have already occurred, resulting in biologically productive environments. 
EXPLANATION

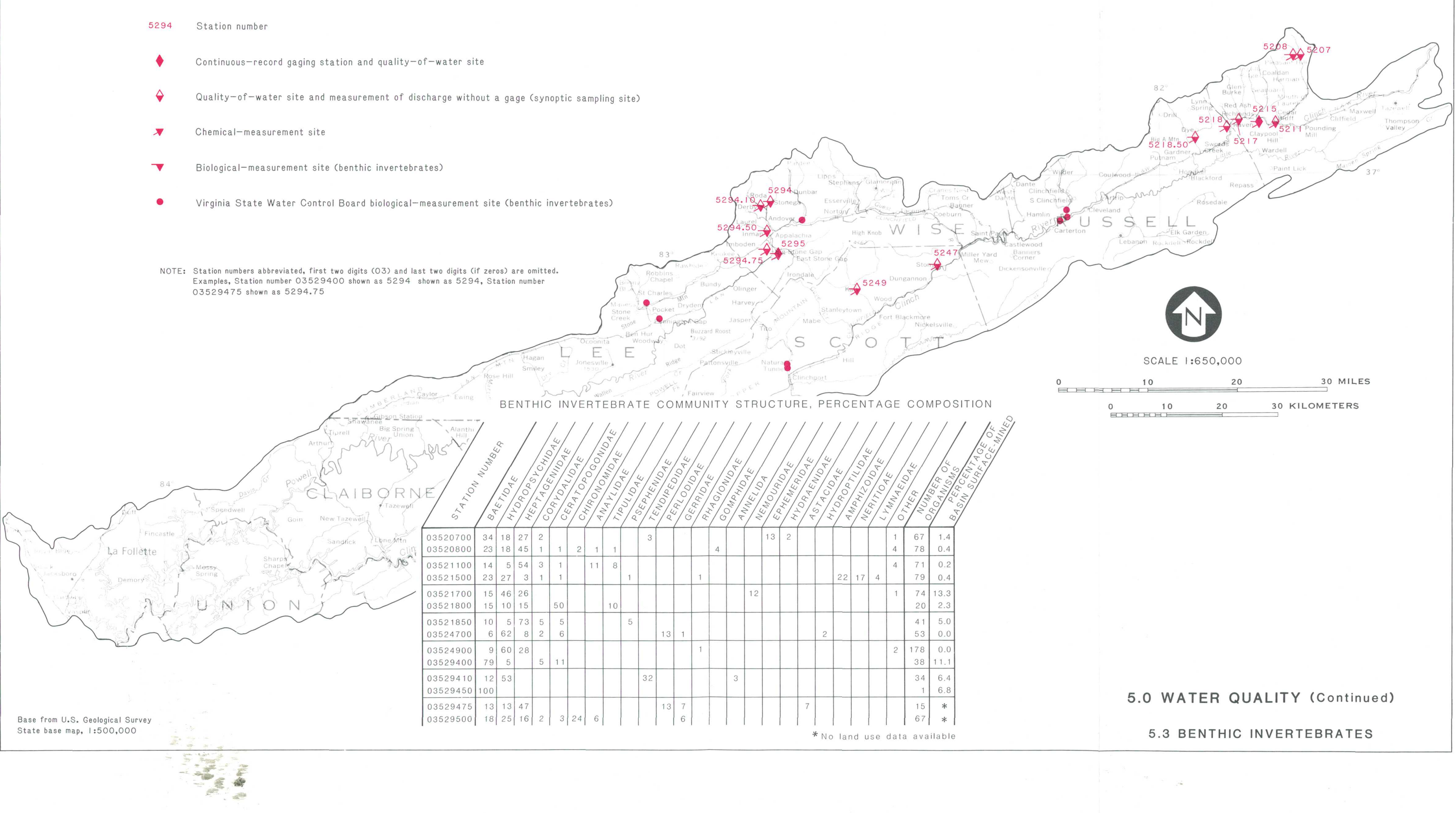




\title{
GROUND WATER IS THE MAJOR SOURCE FOR MANY WATER SUPPLIES IN AREA 16
}

\author{
Ground water from wells and springs is the major source \\ of water for many domestic, commercial, and public \\ supplies. Areas underlain by limestone generally \\ have the highest ground-water yields.
}

\begin{abstract}
Ground-water yield is greater from limestone, dolomite, and shale underlying the Valley and Ridge province than from sandstone and shale underlying the Appalachian Plateau province. Well yields range from 5 to 200 gallons per minute $(\mathrm{gal} / \mathrm{min})$; springs yield from 1 to $1,000 \mathrm{gal} / \mathrm{min}$.

Well yield varies depending on the type of rock and number and size of openings penetrated, and the physical setting of the well site. The most productive sites are located in major stream valleys. The general
\end{abstract}

ground-water flow is from topographic high areas to topographic lows.

Discharge of springs is highly variable due to factors such as head differential determined by topographic location (hillside or valley), changes in storage, seasonal precipitation, and the nature of rock material or conduit conducting water to a spring. The most productive springs discharge from cavernous limestone. 


\title{
6.0 GROUND WATER (Continued) \\ 6.2 DISCHARGE AND MOVEMENT
}

\section{GROUND-WATER DISCHARGE RANGES FROM 1 TO 17 INCHES ANNUALLY}

\author{
Ground-water discharge, estimated from long-term streamflow \\ data, ranges from 1 to 17 inches annually.
}

\begin{abstract}
Under natural conditions, a long-term equilibrium exists between ground water entering and leaving an aquifer system. Ground-water recharge, estimated from streamflow data, should approach the longterm average ground-water discharge contributing to streamflow. In the Clinch and Powell River basins in the Appalachian Region, Wyrick (1968) estimated the ground-water contribution to streamflow at 1 to 2 inches. He assumed that the streamflow value which was equalled or exceeded 90 to 95 percent of the time was derived entirely from ground water. However, this estimate is very conservative; it was used to predict the minimum ground water available on a regional basis. Trainer and Watkins (1975) estimated that the ground water contribution to baseflow of streams in the upper Potomac River basin corresponds to value of streamflow which was equalled or exceeded from 39 to 61 percent of the time and averaged 52 percent. The upper Potomac River basin lies in the same major physiographic provinces as Area 16. Streamflow measurements made in September 1979 (see section 4.2) were made during a period
\end{abstract}

when flow at long-term stations was at about the level that is equalled or exceeded 65 percent of the time. Therefore, these flows should be reasonable first approximations of regional ground-water discharge. Thus, mean annual ground-water discharge and recharge may range from 1 to 17 inches in Area 16. Regional variability has been described in section 4.2.

The actual flow pattern and ground-water storage will vary, depending on the type of rock. In the weathered surficial zone that overlies the bedrock in most of Area 16, water moves and is stored in the interstitial openings between the clay and silt interspersed with some fine to medium sand and chert which comprise this rock. In the coal, limestone, sandstone, siltstone and shale, water moves and is stored along bedding planes, and in joint systems and fractures in the rocks. In limestone, these openings may be enlarged by the solution of calcium carbonate by ground water as it moves along the bedding planes, joints, and fractures. 


\title{
7.0 GROUND-WATER QUALITY
}

\section{GROUND-WATER QUALITY IS HIGHLY VARIABLE IN AREA 16}

\author{
The chemical quality of ground water in Area 16 is highly \\ variable but is generally suitable for most uses.
}

\begin{abstract}
Quality of ground water in Area 16 is highly variable, but it is generally suitable for most uses. The chemical quality of selected ground-water samples is shown on the facing page. The trilinear diagrams (Piper, 1944) show percentages of total anion and cation composition (in milliequivalents per liter) of water from wells in both coal-bearing and noncoalbearing strata. Carbonate rocks, such as limestone, yield calcium magnesium bicarbonate type water. Calcium magnesium sulfate type water is characteristic from sandstones common in Pennsylvanian coalbearing strata. Water hardness varies considerably with both rock types from soft to very hard.
\end{abstract}

Ground-water quality is affected by many factors including rock type, duration of water contact with a particular rock type, and contamination by septic systems. Although dissolved-solids concentrations in ground water in Area 16 are generally low, locally high concentrations of iron, sulfate, and hardness may make water unsuitable for some uses. In some areas high concentrations of chloride and nitrate suggest contamination from septic systems. Wells drilled to depths greater than 200 to 300 feet below land surface in or near major river valleys may yield slightly to moderately saline water. 


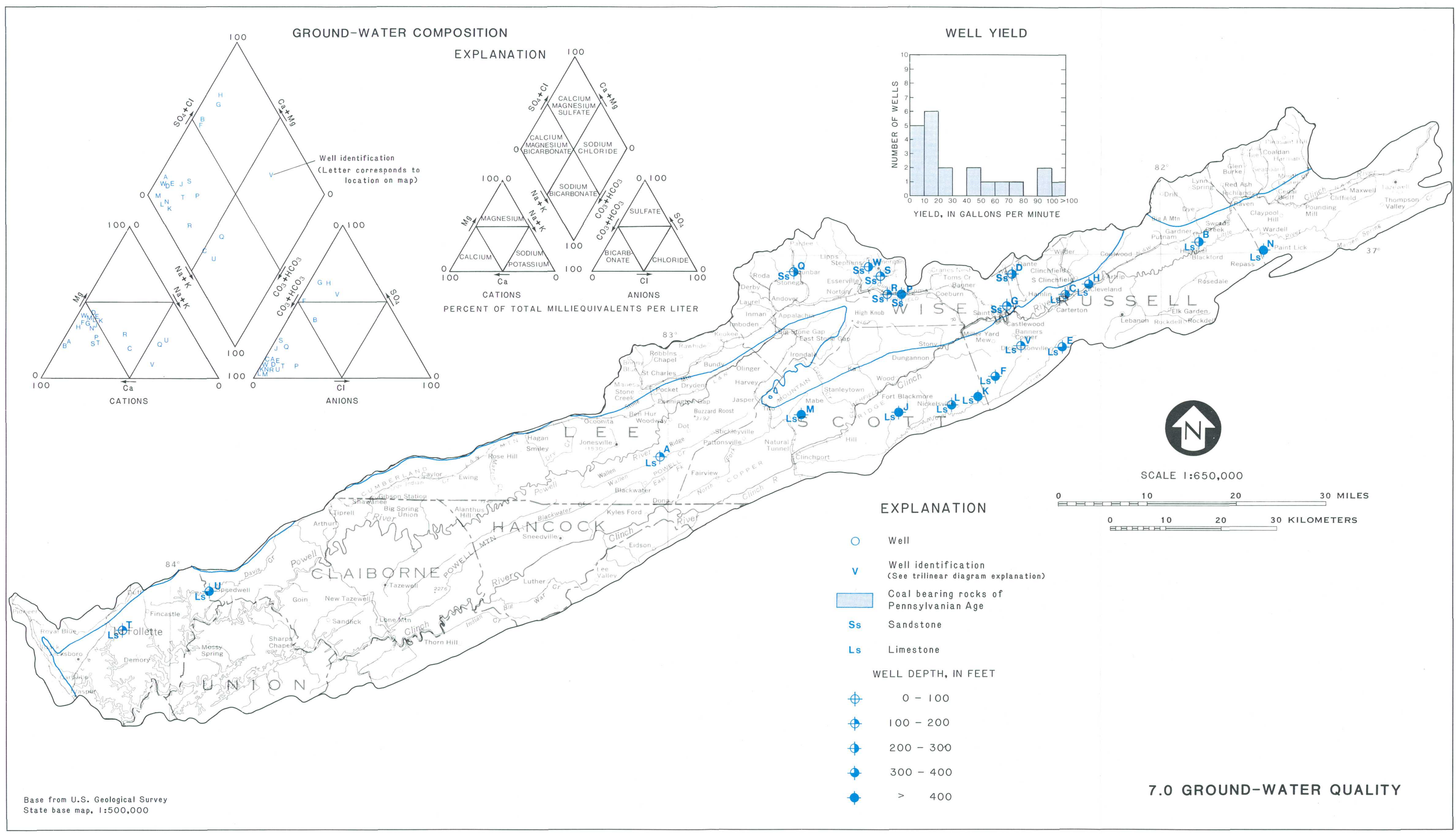




\title{
8.0 WATER-DATA SOURCES \\ 8.1 INTRODUCTION
}

\section{NAWDEX, WATSTORE, OWDC HAVE WATER DATA INFORMATION}

\author{
Water data are collected in coal areas by a large \\ number of organizations in response to a wide \\ variety of missions and needs.
}

Within the U.S. Geological Survey there are three activities that help to identify and improve access to the vast amount of existing water data.

(1) The National Water Data Exchange (NAWDEX), which indexes the water data available from over 400 organizations, serves as a central focal point to help those in need of water data to determine what information already is available.

(2) The National Water Data Storage and Retrieval System (WATSTORE), serves as the central repository of water data collected by the U.S. Geological Survey and contains large volumes of data on the quantity and quality of both surface and ground waters.

(3) The Office of Water Data Coordination (OWDC) coordinates Federal water-data acquisition activities and maintains a "Catalog of Information on Water Data." To assist in identifying available water-data activities in coal provinces of the United States, special indexes to the Catalog are being printed and made available to the public.

A more detailed explanation of these three activities is given in sections $8.2,8.3$, and 8.4. 


\title{
8.0 WATER-DATA SOURCES (Continued) \\ 8.2 NATIONAL WATER-DATA EXCHANGE-NAWDEX
}

\section{NAWDEX SIMPLIFIES ACCESS TO WATER DATA}

\begin{abstract}
The National Water-Data Exchange (NAWDEX) is a nationwide program managed by the U.S. Geological Survey to assist users of water data or water-related data in identifying, locating, and acquiring needed data.
\end{abstract}

NAWDEX is a national confederation of wateroriented organizations working together to make their data more readily accessible and to facilitate a more efficient exchange of water data.

Services are available through a Program Office located at the U.S. Geological Survey's National Center in Reston, Virginia, and a nationwide network of Assistance Centers located in 45 states and Puerto Rico, which provide local and convenient access to NAWDEX facilities (see fig. 8.2-1). A directory is available on request that provides names of organizations and persons to contact, addresses, telephone numbers, and office hours for each of these locations [Directory of Assistance Centers of the National Water Data Exchange (NAWDEX), U.S. Geological Survey Open-File Report 79-423 (revised)].

NAWDEX can assist any organization or individual in identifying and locating needed water data and referring the requester to the organization that retains the data required. To accomplish this service, NAWDEX maintains a computerized Master Water Data Index (fig. 8.2-1), which identifies sites for which water data are available, the type of data available for each site, and the organization retaining the data. A Water Data Sources Directory (fig. 8.2-3) also is maintained that identifies organizations that are sources of water data and the locations within these organizations from which data may be obtained. In addition, NAWDEX has direct access to some large water-data bases from its members and has reciprocal agreements for the exchange of services with others.

Charges for NAWDEX services are assessed at the option of the organization providing the requested data or data service. Search assistance services are provided free by NAWDEX to the greatest extent possible. Charges are assessed, however, for those requests requiring computer cost, extensive personnel time, duplicating services, or other costs encountered by NAWDEX in the course of providing services. In all cases, charges assessed by NAWDEX Assistance Centers will not exceed the direct costs incurred in responding to the data request. Estimates of cost are provided by NAWDEX upon request and in all cases where costs are anticipated to be substantial.

For additional information concerning the NAWDEX program or its services, contact:

Program Office

National Water Data Exchange (NAWDEX)

U.S. Geological Survey

421 National Center

12201 Sunrise Valley Drive

Reston, VA 22092

Telephone: (703) 860-6031

FTS 928-6031

Hours: 7:45 - 4:15 Eastern Time

or

\author{
NAWDEX ASSISTANCE CENTER \\ VIRGINIA \\ U.S. Geological Survey \\ Water Resources Division \\ Room 304 \\ 200 W. Grace Street \\ Richmond, VA 23220
}

Telephone: (804) 771-2427

FTS $925-2427$

Hours: 8:00 - 4:45 Eastern Time 


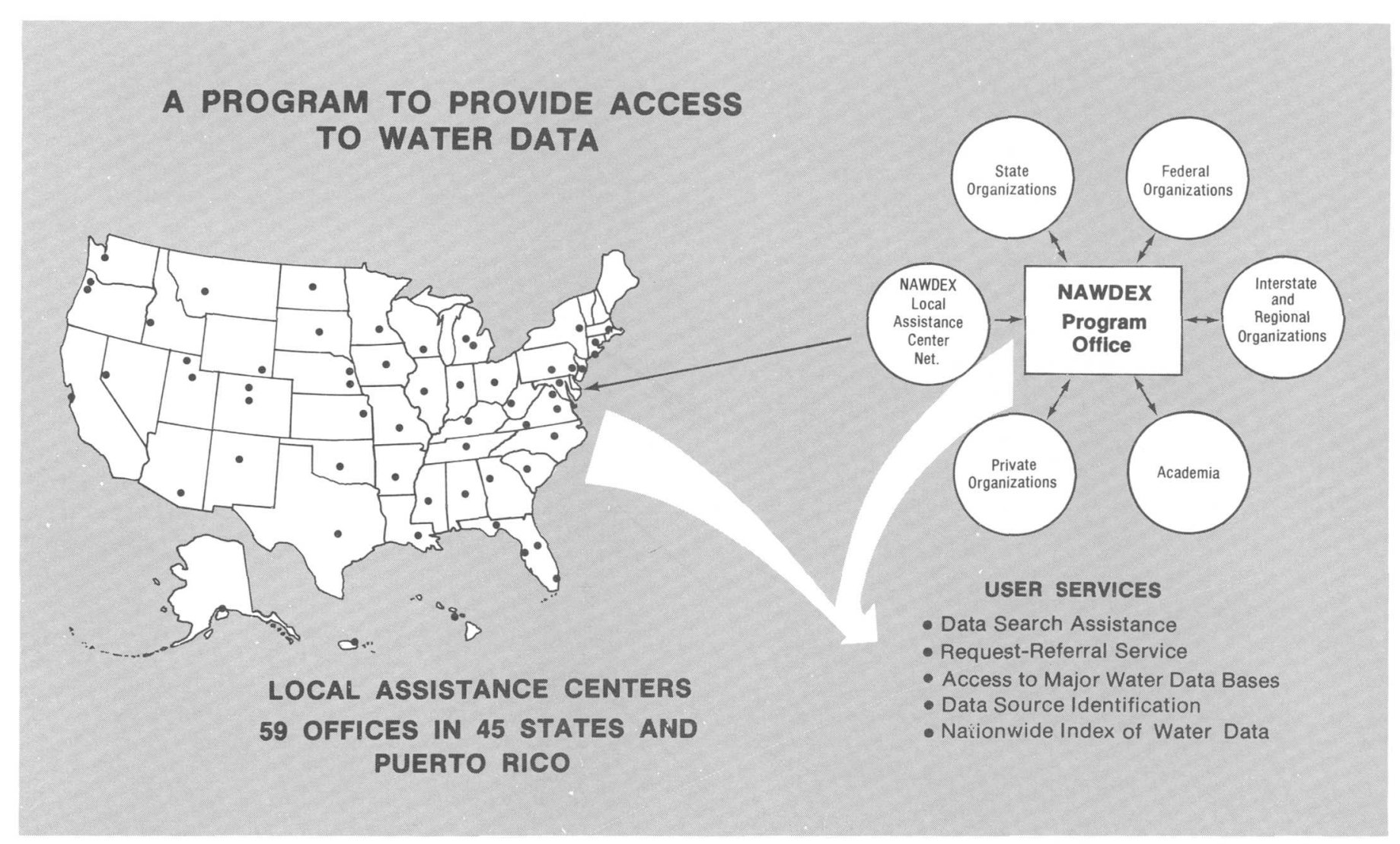

Figure 8.2-1 Access to water data

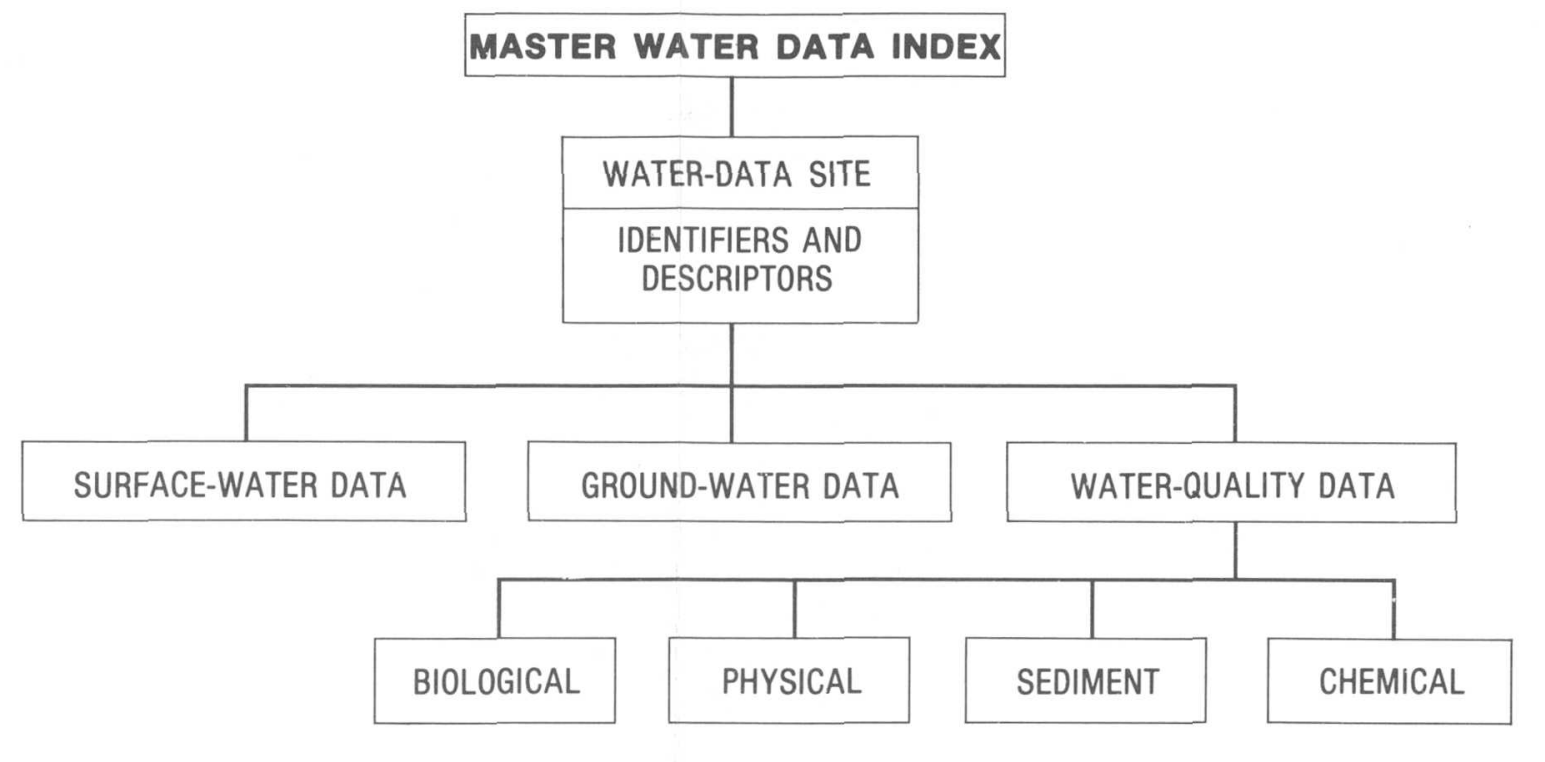

Figure 8.2-2 Master water-data index

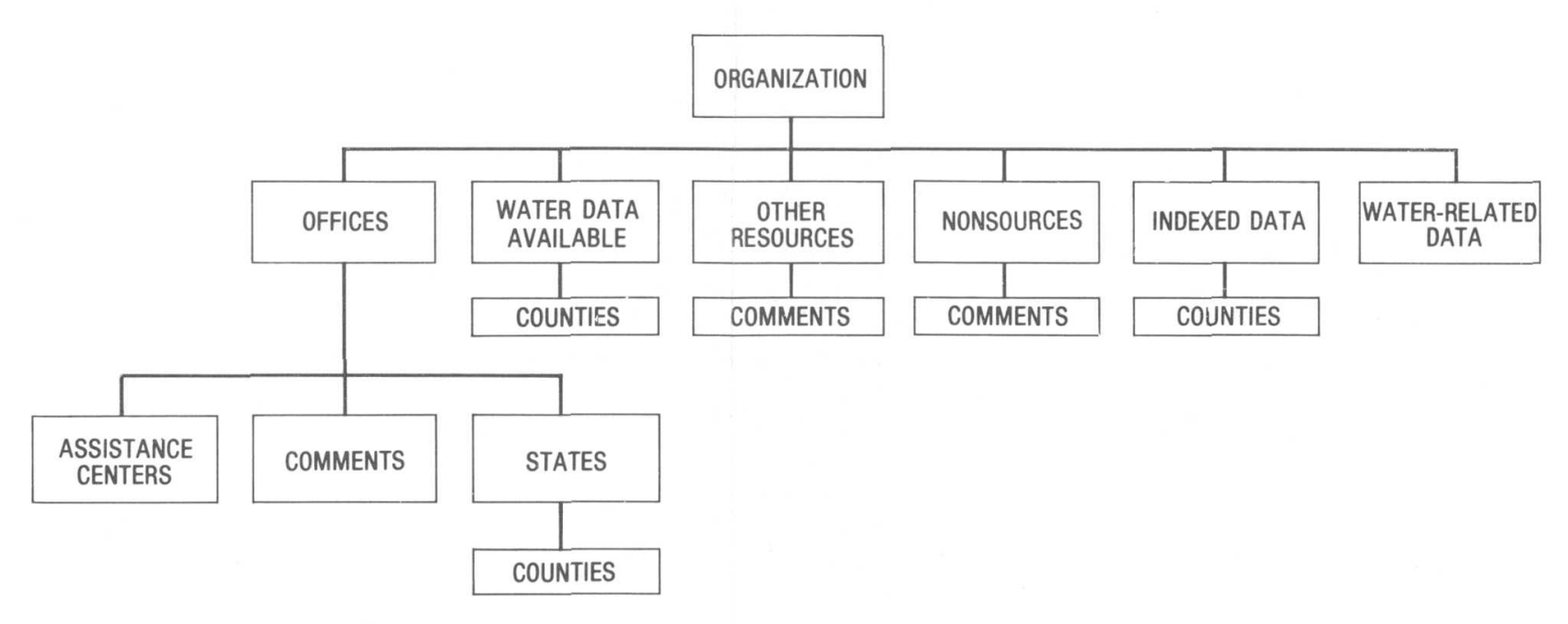

Figure 8.2-3 Water-data sources directory 


\title{
8.0 WATER-DATA SOURCES (Continued) 8.3 WATSTORE
}

\section{WATSTORE AUTOMATED DATA SYSTEM}

\author{
The National Water Data Storage and Retrieval \\ System (WATSTORE) of the U.S. Geological Survey \\ provides computerized procedures and techniques \\ for processing water data and provides effective \\ and efficient management of data-releasing \\ activities.
}

The National Water Data Storage and Retrieval System (WATSTORE) was established in November 1971 to computerize the U.S. Geological Survey's existing water-data system and to provide for more effective and efficient management of its data-releasing activities. The system is operated and maintained on the central computer facilities of the Survey at its $\mathrm{Na}$ tional Center in Reston, Va. Data may be obtained from WATSTORE through the Water Resources Division's 46 district of fices. General inquiries about WATSTORE may be directed to:

Chief Hydrologist

U.S. Geological Survey

437 National Center

Reston, VA 22092

or

$$
\begin{gathered}
\text { U.S. Geological Survey } \\
\text { Water Resources Division } \\
\text { Room } 304 \\
200 \text { W. Grace Street } \\
\text { Richmond, VA } 23220
\end{gathered}
$$

The Geological Survey currently (1980) collects data at approximately 16,000 stream-gaging stations, 1,000 lakes and reservoirs, 5,200 surface-water quality stations, 1,020 sediment stations, 30,000 waterlevel observation wells, and 12,500 ground-water quality wells. Each year many water data-collection sites are added and others are discontinued; thus, large amounts of diversified data, both current and historical, are amassed by the Survey's data-collection activities.

The WATSTORE system consists of several files in which data are grouped and stored by common characteristics and data-collection frequencies. The system also is designed to allow for the inclusion of additional data files as needed. Currently, files are maintained for the storage of: (1) surface-water, quality-of-water, and ground-water data measured on a daily or continuous basis; (2) annual peak values for streamflow stations; (3) chemical analyses for surface- and ground-water sites; (4) water parameters measured more frequently than daily; and (5) geologic and inventory data for ground-water sites. In addition, an index file of sites for which data are stored in the system is also maintained (fig. 8.3-1). A brief description of each file is as follows:

Station Header File: All sites for which data are stored in the Daily Values, Peak Flow, Water-Quality, and Unit Values files of WATSTORE are indexed in this file. It contains information pertinent to the identification, location, and physical description of nearly 220,000 sites.

Daily Values File: All water-data parameters measured or observed either on a daily or on a continuous basis and numerically reduced to daily values are stored in this file. Instantaneous measurements at fixed-time intervals, daily mean values, and statistics such as daily maximum and minimum values also may be stored. This file currently contains over 200 million daily values including data on streamflow, river stages, reservoir contents, water temperatures, specific conductance, sediment concentrations, sediment discharges, and ground-water levels.

Peak Flow File: Annual maximum (peak) streamflow (discharge) and gage height (stage) values at surface-water sites comprise this file, which currently contains over 400,000 peak observations.

Water-Quality File: Results of over 1.4 million analyses of water samples that describe the chemical, physical, biological, radiochemical characteristics of both surface and ground waters are contained in this file. These analyses contain data for 185 different constituents. 
Unit Values File: Water parameters measured on a schedule more frequent than daily are stored in this data are examples of the types of data stored in the Unit Values File.

Ground-Water Site-Inventory File: This file is aintained within WATSTORE independent of the files discussed above, but it is cross referenced to the Water-Qualty $\mathrm{Fle}$ and the Dally alues Fle. Il consources of ground water. The data included are site location and identification, geohydrologic characteristics, well-construction history, and one-time field measurements such as water temperature. The file is designed to accommodate 255 data elements and rently contains data for nearly 700,000 sites.

All data files of the WATSTORE system are maintained and managed on the central compute Center. However, data may be entered into or retrieved from WATSTORE at a number of location that are part of a nationwide telcombrion net-

Remote Job Entry Sites: Almost all of the Water with high-speed computer terminals for remote access to the WATSTORE system.

These terminals allow each site to put data into or retrieve data from the system within several miplaced on the request. The number of remote job entry sites is increased as the need arises.

Digital Transmission Sites: Digital recorders are used at many field locations to record values for parameters such as river stages, conductivity, water ides. Data are recorded on 16-channel paper tape, which is removed from the recorder and transmitted over telephone lines to the receiver at Reston, $V a$. The data are recorded on magnetic tape for use on the central computer. Extensive testing of satellite data-collection platforms indicates their feasibility scale. Battery-operated radios are used as the com-. munication link to the satellite. About 200 data-relay stations were operated in 1980.

Central Laboratory System: The Water Resources Division's two water-quality laboratories, located in Denver, Colo. and Allana, Ga., andyze laboratories are equipped to automatically perform chemical analyses ranging from determinations of comple inorganic compounds, such as chlorides, to each analysis is completed, the results are verified by aboratory personnel and transmitted via a computer terminal to the central computer facilities to be stored in the Water-Quality File of WATSTORE.

Water data are used in many ways by decisionmakers for the management, development, and data processing storage, and retrieval capabilities, WATSTORE can provide a variety of useful products ranging from simple data tables to complex statistical analyses. A minimal fee, plus the actual a desired product, is charged to the requester.

Computer-Printed Tables: Users most often request data from WATSTORE in the form of tables printed by the computer. These tables may contain lists of actual data or condensed indexes that indicate the availability of data stored in the files. A variety

Computer-Printed Graphs: Computer-printed graphs for the rapid analysis or display of data are nother capability of WATSTORE. Computer prorams are available to produce bar graphs (histograms), line graphs, frequency distribution orves, $X$ with a proprietary statistical package (SAS) to provide extensive analyses of data such as regression andeses, the analysis of variance, transformations,

Digital Plotting: WATSTORE also makes use of

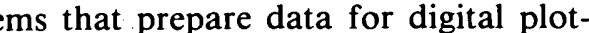
ting on peripheral offline plotters available at the central computer site. Plots that can be obtained include hydrographs, frequency distribution curves,

Data in Machine-Readable Form: Data stored in WATSTORE can be obtained in machine-readable form for use on other computers or for use as input to user-written computer programs. These data are available in the standard storage format of the WATcard images on magnetic tape.

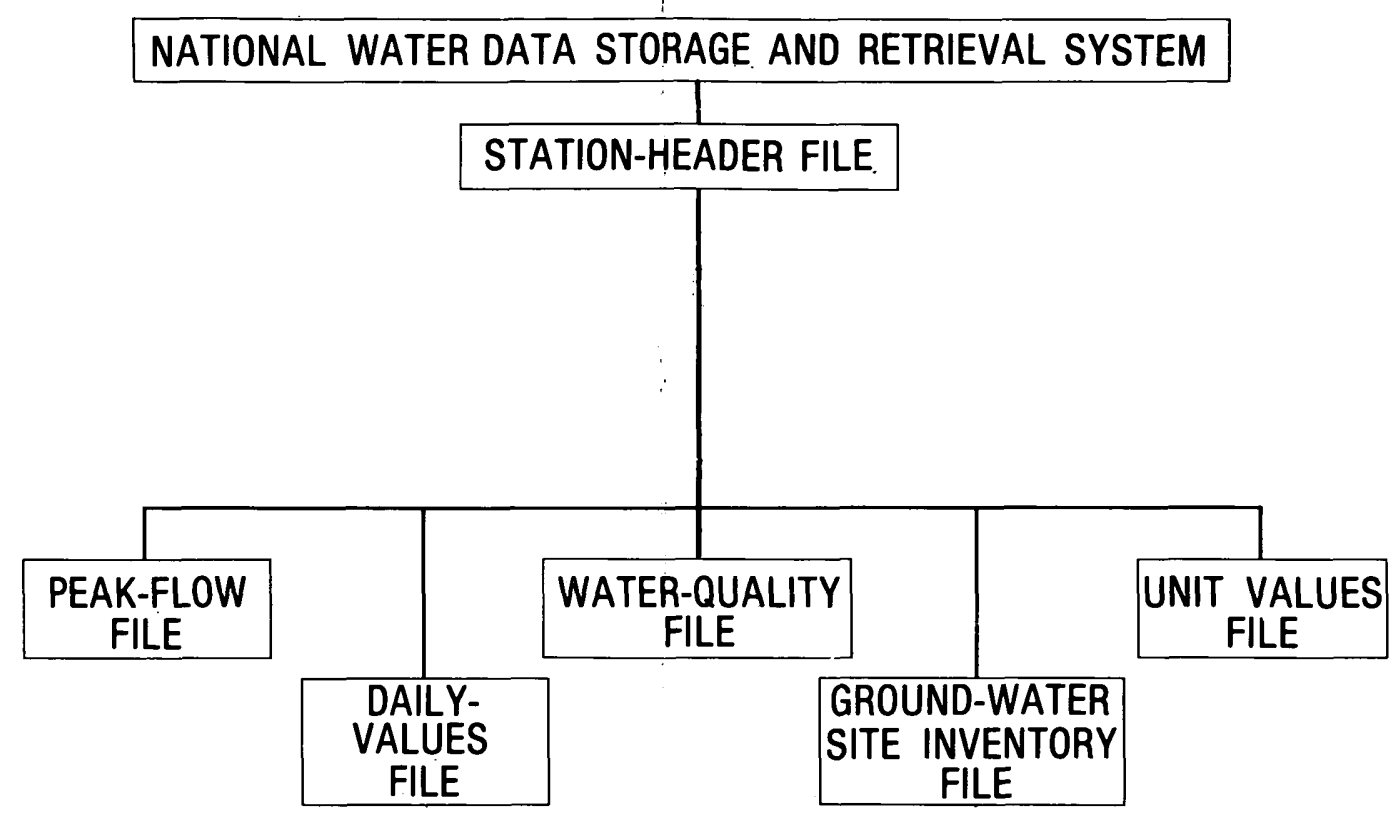

Figure 8.3-1 Index file stored data 


\title{
8.0 WATER-DATA SOURCES (Continued) \\ 8.4 INDEX TO WATER-DATA ACTIVITIES IN COAL PROVINCES
}

\section{WATER DATA INDEXED FOR COAL PROVINCES}

\author{
A special index, "Index to Water-Data Activities \\ in Coal Provinces of the United States, " has been \\ published by the U.S. Geological Survey's Office \\ of Water Data Coordination (OWDC).
}

The "Index to Water-Data Activities in Coal Provinces of the United States" was prepared to assist those involved in developing, managing, and regulating the Nation's coal resources by providing information on the availability of water-resources data in the major coal provinces of the United States. It is derived from the "Catalog of Information on Water Data," which is a computerized information file about water-data acquisition activities in the United States, and its territories and possessions, with some international activities included.

This special index consists of five volumes (fig. 8.4-1): Volume I, Eastern Coal province; Volume II, Interior Coal province; Volume III, Northern Great Plains and Rocky Mountain Coal provinces; Volume IV, Gulf Coast Coal province; and Volume V, Pacific Coast and Alaska Coal provinces. The information presented will aid the user in obtaining data for evaluating the effects of coal mining on water resources and in developing plans for meeting additional water-data needs. The report does not contain the actual data; rather, it provides information that will enable the user to determine if needed data are available.

Each volume of this special index consists of four parts: Part A, Streamflow and Stage Stations; Part B, Quality of Surface-Water Stations; Part C, Quality of Ground-Water Stations; and Part D, Areal Investigations and Miscellaneous Activities. Information given for each activity in Parts A-C includes: (1) the identification and location of the station, (2) the major types of data collected, (3) the frequency of data collection, (4) the form in which the data are stored, and (5) the agency or organization reporting the activity. Part D summarizes areal hydrologic investigations and waier-data activities not included in the other parts of the index. The agencies that submitted the information, agency codes, and the number of activities reported by type are shown in a table.

Those who need additional information from the Catalog file or who need assistance in obtaining water data should contact the National Water Data Exchange (NAWDEX). (See section 8.2).

Further information on the index volumes and their availability may be obtained from:

\author{
U.S. Geological Survey \\ Water Resources Division \\ Room 304 \\ $200 \mathrm{~W}$. Grace Street \\ Richmond, VA 23220
}

Telephone: (804) 771-2427 FTS 925-2427

or

Office of Surface Mining

U.S. Department of the Interior 530 Gay St., Suite 500

Knoxville, TN 37902

Telephone: (615) 637-8060

FTS 852-0060 


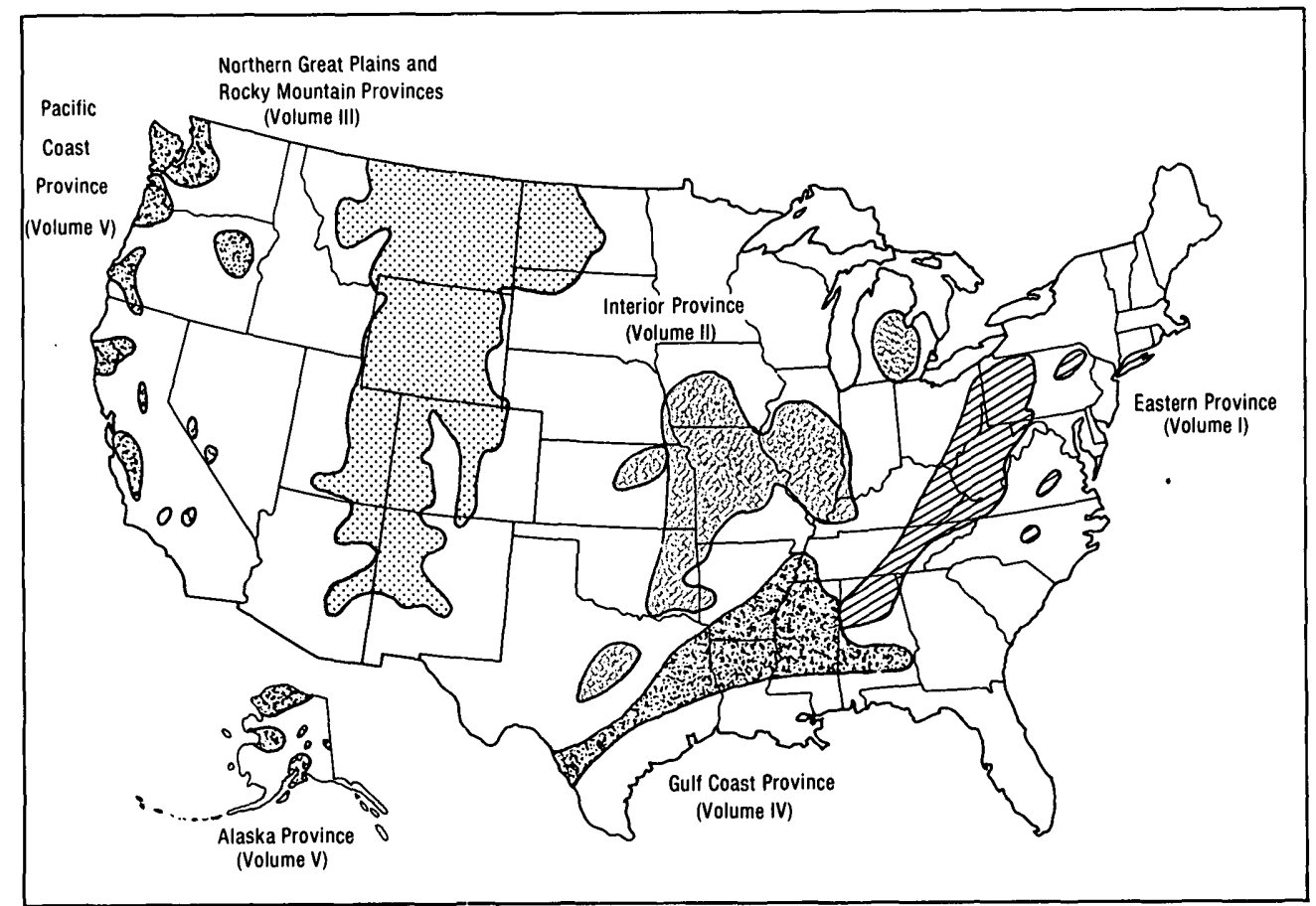

Figure 8.4-1 Index volumes and related provinces 


\subsection{SELECTED REFERENCES}

Butts, Charles, 1940, Geology of the Appalachian Valley in Virginia: Virginia Geological Survey Bulletin 52, Pt. 1, pp. 4-6.

Crittenden, M. D., Jr., and Pavlides, Louis, compilers, 1962, Manganese in the United States, exclusive of Alaska and Hawaii: U.S. Geological Survey Mineral Resources Map MR23, Scale $1: 3,168,000$ (separate text).

Epps, Susan R., 1978, Buchanan County ground water, present conditions and prospects: Virginia State Water Control Board Planning Bulletin $311,75 \mathrm{p}$.

Fenneman, N. M., 1938, Physiography of the eastern United States: McGraw-Hill Inc., New York. $724 \mathrm{p}$.

Gooch, E. O., 1954, Iron in Virginia: Virginia Division of Geology Mineral Resources Circular, pp. $1-17$.

Guy, H. P., and Norman, V. W., 1970, Field methods for measurement of fluvial sediment: U.S. Geological Survey Techniques of Water Resources Investigations, book 3, Chap. C2, $59 \mathrm{p}$.

Hem, John D., 1970, Study and interpretation of the chemical characteristics of natural water: U.S. Geological Survey Water Supply Paper 1973, 363 p.

Krauskopf, Konrad B., 1967, Introduction to geochemistry: McGraw-Hill Inc., New York! 721 p.

McGill, William M., 1936, Outline of the mineral resources of Virginia: Virginia Geological Survey Bulletin 47, Series 3, 81 p.

Piper, A. M., 1944, A graphic procedure in the geochemical interpretation of water analyses: American Geophysical Union Trans., v. 25, pp. 914-923.

Rogers, Stanley M., and Hufschmidt, P. W., 1980, Quality of surface water in the coal mining area of southwest Virginia: U.S. Geological Survey Water Resources Investigations Open-File Report 80-769, 2 sheets.

Skougstad, Marvin W., Fishman, M. J., Friedman, C. C., Endmann, D. E., and Duncan, S. S., editors, 1979, Methods for determination of inorganic substances in water and fluvial sediments: Techniques of Water Resources Investigations of the U.S. Geological Survey, Book 5, Chapter Al, $626 \mathrm{p}$.
Southwest Virginia 208 Planning Agency, 1977, Southwest Virginia 208 Plan Map Volume.

- $\ldots$ - _ _ , 1978, Southwest Virginia 208 Plan, $421 \mathrm{p}$

Tennessee Division of Geology, 1966, Geologic Map of Tennessee, East Sheet: Knoxville, Tennessee.

Tennessee Valley Authority, 1977-1979, Precipitation in the Tennessee River basin, vols. January through December, 1977 to 1979.

Trainer, Frank W., and Watkins, F. A., Jr., 1975, Geohydrologic Reconnaissance of the Upper Potomac River basin: U.S. Geological Survey Water Supply Paper 2035, 68 p.

U.S. Department of Agriculture, 1979, General Soil Map, State of Virginia: U.S. Soil Conservation Service. 1 sheet.

U.S. Department of Commerce, 1977-1979, Climatological Data, Virginia: National Oceanographic and Atmospheric Administration, Vols. 88, 89, $90,15 \mathrm{p}$.

U.S. Environmental Protection Agency, 1976, Erosion and sediment control, surface mining in the eastern U.S. Planning Volume 1: EPA Report 625/3-76-006 Vol. 1, 102 p.

_ $-\ldots \ldots$, 1976, Quality criteria for water: U.S. Environmental Protection Agency, Washington, D.C., $256 \mathrm{p}$.

_ _ _ _ _ , 1977, National interim primary drinking water regulations: EPA Report 570/9-76-003, $159 \mathrm{p}$.

U.S. Geological Survey and U.S. Bureau of Mines, 1968, Mineral resources of the Appalachian region: U.S. Geological Survey Professional Paper $580,494 \mathrm{p}$.

U.S. Geological Survey, 1977, National handbook of recommended methods of water data acquisition: U.S. Geological Survey, Office of Water Data Coordination.

Virginia Division of Mineral Resources, 1963, Geologic map of Virginia, Charlottesville, Virginia. 1 sheet.

Wyrick, Granville, G., 1968, Ground-water resources of the Appalachian region: U.S. Geological Survey Hydrologic Investigations Atlas HA295, 4 sheets. 


\subsection{APPENDIX}

\section{STATION IDENTIFICATION}

NUMBER NAME

03520700

INDIAN CREEK AT HARMAN, VA.

03520800

GREASY CREEK AT HARMAN, VA.

03521100

MIDDLE CREEK AT CEDAR BLUFF, VA.

03521500

CLINCH RIVER AT RICHLANDS, VA.

03521600

BIG CREEK AT RICHLANDS, VA.

03521650

03521700

03521800

03521850

03521900

03522525

03522550

03522600

TOWNHILL CREEK AT DORAN, VA.

MUDLICK CREEK AT DORAN, VA.

MILL CREEK AT RAVEN, VA.

SWORDS CREEK NEAR DYE, VA.

HESS CREEK NEAR DYE, VA.

GRASSY CREEK NEAR DRILL, VA.

FLATROCK CREEK NEAR DRILL, VA.

LEWIS CREEK AT HONAKER, VA.

03523000

CEDAR CREEK NEAR LEBANON, VA.

03523650

THOMPSON CREEK AT ARTRIP, VA.

03523700

WEAVER CREEK AT ARTRIP, VA.

03524000

CLINCH RIVER AT CLEVELAND, VA.

DUMPS CREEK NEAR S. CLINCHFIELD, VA.

HURRICANE FORK NEAR S. CLINCHFIELD, VA.

03524010

03524030

03524050

03524060

03524070

03524340

03524346

03524348

03524500

03524700

03524870

03524880

03524890

03524900

03525100

03525490

03527000

03527480

03527490

CHANEY CREEK NEAR S. CLINCHFIELD, VA.

LICK CREEK AT ST. PAUL, VA.

RUSSELL CREEK NEAR ST. PAUL, VA.

BULL RUN NEAR ST. PAUL, VA.

GUEST RIVER AT NORTON, VA.

BEAR CREEK NEAR WISE, VA.

YELLOW CREEK NEAR WISE, VA.

GUEST RIVER AT COEBURN, VA.

LITTLE STONY CREEK NEAR DUNGANNON, VA.

STONY CREEK NEAR KA, VA.

STRAIGHT FORK NEAR KA, VA.

DEVIL FORK NEAR KA, VA.

STONY CREEK AT KA, VA.

COVE CREEK NEAR STANLEYTOWN, VA.

STOCK CREEK AT CLINCHPORT, VA.

CLINCH RIVER AT SPEERS FERRY, VA.

NORTH FORK CLINCH RIVER NEAR DUFFIELD, VA.

DRY BRANCH NEAR DUFFIELD, VA.

03528000

03529300

CLINCH RIVER ABOVE TAZEWELL, TN.

03529310

POWELL RIVER NEAR NORTON, VA.

03529315

ROARING FORK AT DUNBAR, VA.

POTCAMP CREEK AT DUNBAR, VA.

03529400

03529410

03529450

03529475

03529500

03529800

03529900

03530400

03530440

CALLAHAN CREEK NEAR STONEGA, VA.

MUDLICK CREEK NEAR STONEGA, VA.

LOONEY CREEK AT APPALACHIA, VA.

ROARING BRANCH AT BIG STONE GAP, VA.

POWELL RIVER AT BIG STONE GAP, VA.

S. FORK POWELL RIVER AT EAST STONE GAP, VA.

BUTCHER FORK AT EAST STONE GAP, VA.

NORTH FORK POWELL RIVER AT POCKET, VA.

STRAIGHT CREEK AT ST. CHARLES, VA. 
STATION IDENTIFICATION -- (Continued)

$\begin{array}{ll}\text { NUMBER } & \text { NAME } \\ 03530460 & \text { BAILEYS TRACE AT ST. CHARLES, VA. } \\ 03530470 & \text { PUCKETT CREEK AT MANESS, VA. } \\ 03530485 & \text { BERGEN BRANCH NR. STONE CR., VA. } \\ 03530490 & \text { ELY CREEK NR STONE CR., VA. } \\ 03530495 & \text { STONE CREEK AT STONE CREEK, VA. } \\ 03530500 & \text { N. FORK POWELL RIVER AT PENNINGTON GAP, VA. } \\ 03531500 & \text { POWELL RIV. NR JONESVILLE, VA. } \\ 03531505 & \text { BATIE CREEK NEAR JONESVILLE, VA. } \\ 03531520 & \text { WALLEN CREEK NEAR JONESVILLE, VA. } \\ 03531530 & \text { HARDY CREEK NEAR SMILEY, VA. } \\ 03531535 & \text { DRY CREEK NEAR SMILEY, VA. } \\ 03533170 & \text { POWELL RIVER NEAR ALANTHUS HILL, TN. } \\ 03532000 & \text { POWELL RIVER NEAR ARTHUR, TN. } \\ 03532070 & \text { OLD TOWN CREEK NEAR RED HILL, TN. } \\ 03532100 & \text { DAVIS CREEK NEAR SPEEDWELL, TN. } \\ 03532200 & \text { BIG CREEK AT LA FOLLETTE, TN. } \\ 03532480 & \text { COVE CREEK ABOVE COVE LAKE, NEAR CARYVILLE, TN. }\end{array}$

